\title{
3. CALCAREOUS NANNOFOSSIL BIOSTRATIGRAPHY OF SITE 865, ALLISON GUYOT, CENTRAL PACIFIC OCEAN: A TROPICAL PALEOGENE REFERENCE SECTION ${ }^{1}$
}

\author{
Timothy J. Bralower ${ }^{2}$ and Jörg Mutterlose ${ }^{3}$
}

\begin{abstract}
A relatively expanded and largely complete upper Paleocene to lower Oligocene sequence was recovered from the pelagic cap overlying Allison Guyot, Mid-Pacific Mountains. The sequence consists of calcareous ooze with a high planktonic foraminifer content. Two separate holes (865B and 865C) were drilled with the advanced piston coring system. Samples from these holes have been the target of intensive calcareous nannofossil biostratigraphic investigations. Calcareous nannofossils are moderately well preserved and diverse throughout the sequence recovered, which extends from nannofossil Zone CP3 to CP16. Our data show that unconformities occur in the uppermost lower Eocene and at the Eocene/Oligocene boundary, correlating to part of Zones CP11 and CP12 and Zones CP15 and CP16, respectively. Most traditional zonal markers are present; however, the rarity of several of them, particularly discoasters, and the overgrowth of others, including species of Tribrachiatus, in the uppermost Paleocene and lower Eocene makes zonal subdivision of part of this sequence difficult. For this reason, more attention has been paid to establishing the precise ranges of nonzonal taxa. We were able to determine 142 zonal and nonzonal events in the Paleogene section by intensively sampling both holes (1-5 samples in each core section). Sample density increased toward the Paleocene/Eocene boundary. Although the events are spread fairly evenly throughout the section, some of the most dramatic turnover occurs in the boundary and early Eocene interval. Currently unobserved gradational forms in nannofossil lineages indicate that parts of this sequence are more expanded than any other yet recovered. Plate reconstructions show that Site 865 was close to the equator at the time Paleogene sediments were deposited. The near completeness, expansion, paleolocation, and shallow burial depth of this sequence render it an ideal low-latitude Paleogene reference section.
\end{abstract}

\section{INTRODUCTION}

Increasing interest is being shown in the record of Paleogene climate change contained in cores of deep-sea sediments (e.g., Stott and Zachos, 1991). This time period witnessed some fairly long-term fluctuations in temperatures (e.g., Shackleton and Kennett, 1975; Savin, 1977), as well as some of the most dramatic changes in the marine microinvertebrate record close to the Paleocene/Eocene and Eocene/Oligocene boundaries (Prothero and Berggren, 1992, and references therein). Expanded and complete deep-sea records of the Paleogene are rare. In many places, sediments of this age are buried deeply enough to have experienced significant diagenetic alteration, which changes original isotopic signatures and deteriorates the record of important biostratigraphic markers. The abundance of chert in many Eocene deep-sea carbonates (e.g., Pisciotto, 1981) has greatly reduced rates of recovery in drilling.

Because of the paucity of good Paleogene records, numerous uncertainties still exist concerning the detailed biostratigraphy of this interval. Even though the original zonations of both planktonic foraminifers (e.g., Blow, 1969) and calcareous nannofossils (Martini, 1971; Bukry, 1973, 1975a, 1975b; Okada and Bukry, 1980) have proven to be widely applicable, the detailed stratigraphy of nonmarker species can be improved. Resolution of Paleogene biostratigraphies of both groups, therefore, lags significantly behind that of the Neogene and, in the case of the calcareous nannofossils, even that of parts of the Cretaceous (Moore and Romine, 1981; Bralower et al., 1993). The Paleogene is an interval of high species diversity nonetheless (Haq, 1973), and the potential for increased biostratigraphic resolution is good.

\footnotetext{
' Winterer, E.L., Sager, W.W., Firth, J.V., and Sinton, J.M. (Eds.), Proc. ODP, Sci. Results, 143: College Station, TX (Ocean Drilling Program).

${ }^{2}$ Department of Geology, University of North Carolina, Chapel Hill, NC 27599-3315, U.S.A.

${ }^{3}$ Institute für Geologie der Ruhr-Universität, Postfach 102148, D-4630 Bochum, Federal Republic of Germany,
}

Recent Ocean Drilling Program (ODP) cruises in high southern latitude sites, ranging from Maud Rise in the Weddell Sea to the Kerguelen Plateau in the Indian Ocean, have recovered several good Paleogene sequences that have been the targets of a host of biostratigraphic and paleoceanographic investigations (see summaries in Wei [1992] and Zachos et al. [1993]). These studies have quickly advanced our knowledge of Paleogene paleoceanography. The relative lack of record is nowhere more apparent than in the Pacific Ocean, where only one good sequence exists. A pelagic section spanning the early Paleogene was recovered at Deep Sea Drilling Project (DSDP) Site 577 on the Shatsky Rise (Heath et al., 1985). This sequence has been the subject of detailed biostratigraphic (Monechi, 1985; Pak and Miller, 1992) and isotopic (e.g., Miller et al., 1987) investigations. The section recovered at Site 577 is almost complete, but it possesses a number of condensed intervals and minor unconformities, particularly in the lower Eocene. Deposited at a paleolatitude close to $20^{\circ} \mathrm{N}$, this sequence is almost the only record for conditions in the Paleogene tropical Pacific Ocean. The potential significance of the Paleogene section in the pelagic cap of Allison Guyot was readily apparent, therefore.

The major objective of Leg 143 was to investigate the evolution and ultimate demise of carbonate platforms in the middle Cretaceous Pacific Ocean. Site 865 was located near the top of Allison Guyot, at a water depth of $1530 \mathrm{~m}$ in the Mid-Pacific Mountains at $18^{\circ} 26^{\prime} \mathrm{N}$, $179^{\circ} 33^{\prime} \mathrm{W}$ (Fig. 1). The first hole (865A) was rotary drilled, penetrating the pelagic cap and about $700 \mathrm{~m}$ of Cretaceous shallow-water carbonates (Figs. 2-3). Because of the likely significance of the Paleogene section recovered in Hole $865 \mathrm{~A}$, two additional holes ( $865 \mathrm{~B}$ and $865 \mathrm{C}$ ) were drilled with the advanced hydraulic piston corer (APC) and the extended core barrel (XCB).

The pelagic cap of a guyot is a most unlikely place to recover a sequence of any age that is relatively expanded and approaches stratigraphic completeness. Sediments deposited in such a hydrographic setting are bound to have experienced winnowing by bottom currents at the time of deposition and shortly thereafter. The effects of this activity are clearly seen in the seismic sections and the bottom photographs (Lonsdale et al., 1972) as well as in the sedimentology of cores collected from guyots. Indeed, the sediments recovered from the pelagic 


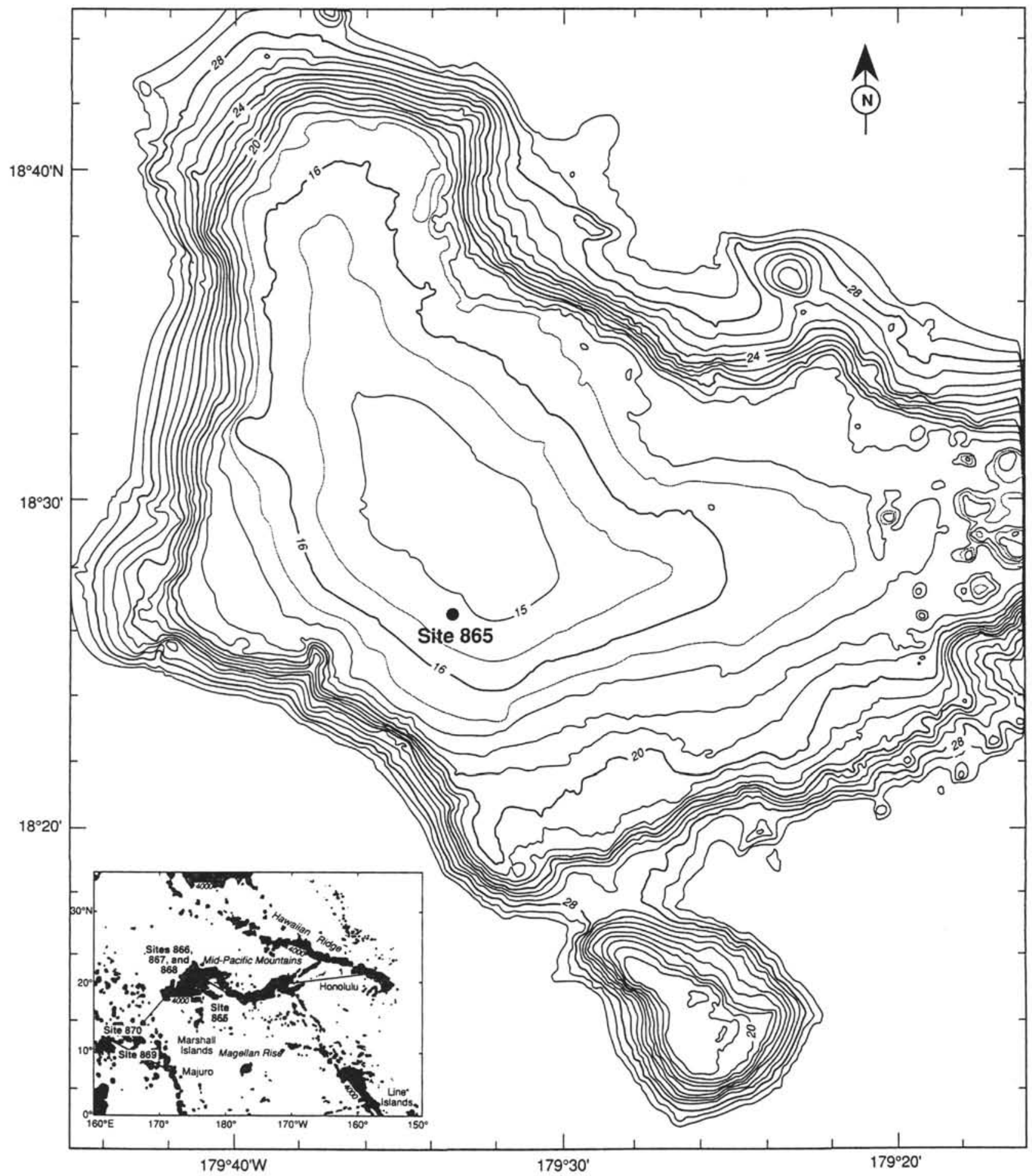

Figure 1. Location of Site 865 on Allison Guyot in the Mid-Pacific Mountains. Bathymetry is in meters. Inset shows regional map and track of the JOIDES Resolution during Leg 143.

cap at Site 865 have anomalous enrichments of planktonic foraminifers over smaller particles including calcareous nannofossils, and a resulting sandy texture. Because of their high porosity $(60 \%-80 \%)$, these sediments were watery, which presented significant problems in handling (particularly in cutting) the cores. Owing to the use of water in drilling, sediments from rotary-drilled Hole $865 \mathrm{~A}$ were in far worse condition than those in the other two holes. The potential problems of seafloor reworking and shipboard contamination have been monitored closely in biostratigraphic investigation. Clearly, a bonus of recovering Paleogene sediments at such shallow burial depths is that the preservation of microfossils, especially planktonic foraminifers, is superb.

The preliminary biostratigraphy of Hole $865 \mathrm{~A}$ is described in Sager, Winterer, Firth, et al. (1993) and is not discussed any further here. The present paper discusses the calcareous nannofossil biostratigraphy of 


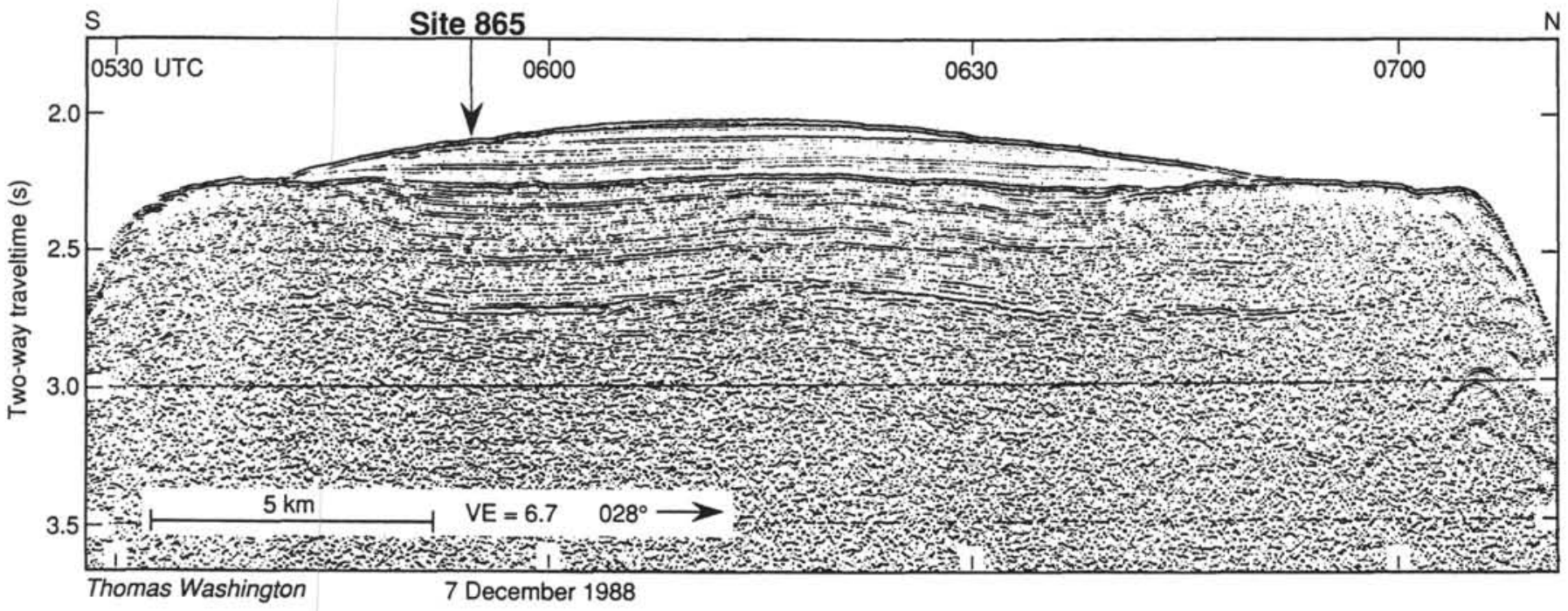

Figure 2. North-south seismic profile through Allison Guyot showing the location of Site 865. Parallel, horizontal reflectors at the top of the sediment column represent the pelagic cap sequence. Underlying dipping and wavy reflectors represent the Cretaceous shallow-water section. VE $=$ vertical exaggeration.

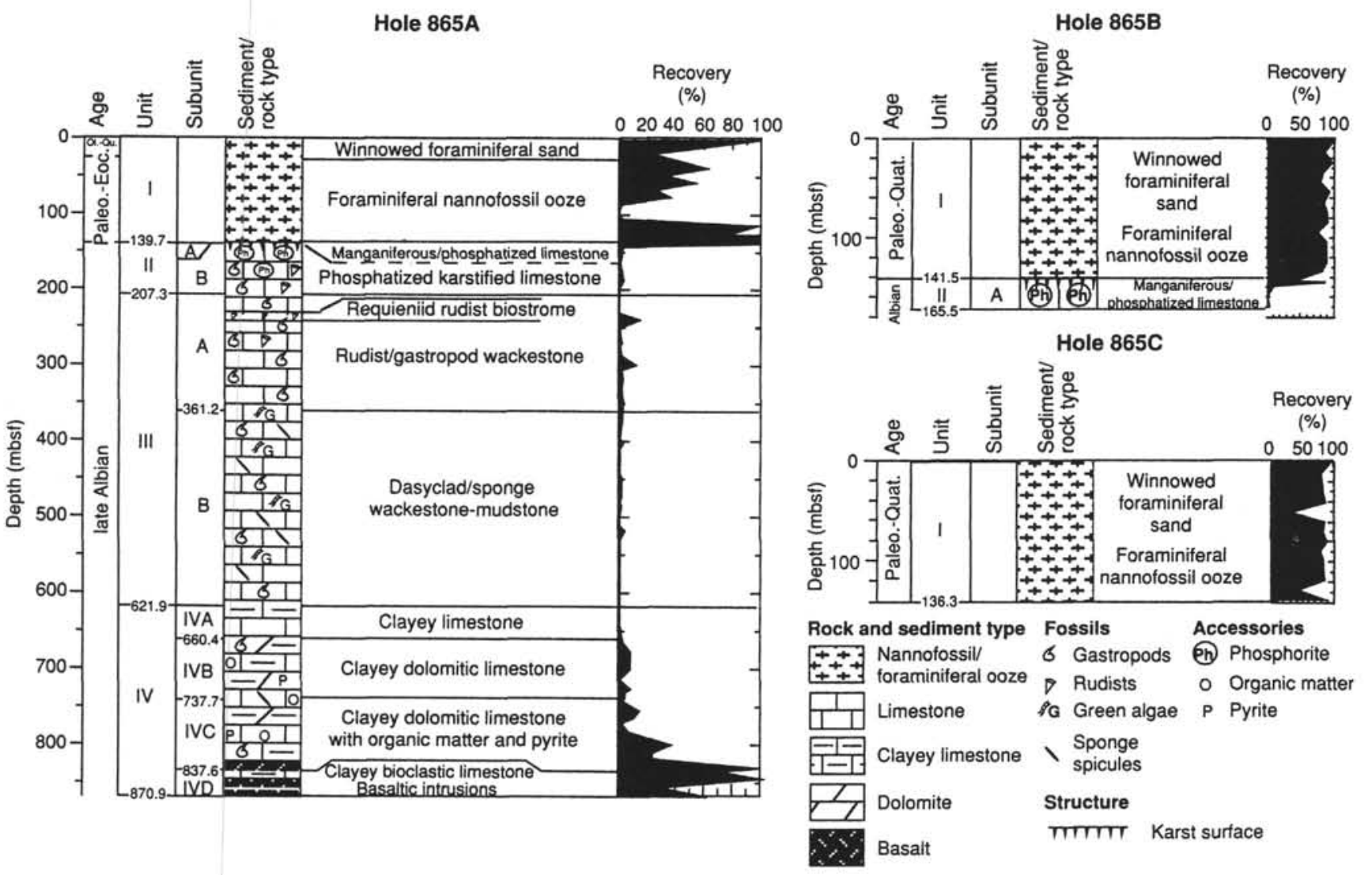

Figure 3. Generalized lithologic column of sediments recovered in Holes 865A, 865B, and 865C. Core recovery is shown in graph at right of lithologic diagram.

Holes $865 \mathrm{~B}$ and $865 \mathrm{C}$. Several traditionally used Paleogene zonal markers are absent or rare in sediments at Site 865. Other markers are overgrown to the point that establishing their ranges precisely is difficult, if not impossible. Similar problems have been encountered in other Paleogene sequences (e.g., Monechi, 1985). One of the major goals of this investigation, therefore, was to establish in detail the stratigraphic ranges of more than 100 potential secondary markers. Because of the rarity and scattered occurrence of many of these mark- ers, accurately establishing their ranges requires collection of a closely spaced sample set and preparation of thick smear slides.

The scheme presented here is a first attempt at such a relatively high-resolution Paleogene nannofossil biostratigraphy. It is clear, however, that before such a scheme can become widely applicable, it must be compared in detail with the results of similarly intensive investigations in other sections from a variety of different latitudes, ocean basins, and settings. In addition, the taxonomy of Paleogene 
calcareous nannofossils suffers from numerous problems. In particular, definitions of certain species vary significantly among different biostratigraphers, and the need for quantitative biometric investigations of individual species and lineages is obvious (e.g., Wei, 1992). Such taxonomic problems lessen the precision of correlation among the most important Paleogene sequences.

\section{METHODS AND PROCEDURES}

This biostratigraphic investigation is based on observing one to five samples in each core section. The number of samples observed was higher in the Paleocene to lower Eocene sequence and lower in the middle Eocene to lower Oligocene one. Increasing the number of samples observed led to a significant increase in the precision with which many biostratigraphic events could be determined. This is because the occurrences of these species are so patchy near their first (FOs) and last (LOs) occurrences that minor sample-to-sample fluctuations in the abundances of these taxa often influenced whether none or one or two specimens were observed. Therefore, our approach has been to look at a large number of samples to infer the total range of a taxon, and then to fill the gaps in its range, based on subsequent observations. The combination of stratigraphies from two separate holes ( $865 \mathrm{~B}$ and $865 \mathrm{C}$ ) also helped establish the ranges of these rare taxa. Because they were drilled so close together, the meter levels of most events in the two holes turned out to be similar. Fluctuations in abundance and sample location might have initially resulted in a more extended range in one hole. Consequent observation in the corresponding meter range in the other hole usually led to an extension of the same range. Special attention was paid to samples in important stratigraphic intervals, especially toward the ends of species ranges. Where critical, additional samples were inserted to attempt to separate the levels of events that lie in close proximity. All investigations were made on dense smear slides to observe the occurrences of rare taxa.

Certain groups of nannofossils, particularly the discoasters, proved to be difficult to study, owing to a combination of taxonomic and preservational factors. In the case of taxa having little proven biostratigraphic usefulness (e.g., the genus Pontosphaera), species were combined. Because the ranges of many species are sensitive to the concepts used, taxonomic discussions of most markers are provided in the Appendix. For most taxa, we tried to use generally accepted taxonomic concepts, especially where these were described in comprehensive syntheses (Aubry, 1984, 1988, 1989, 1990; Perch-Nielsen, 1985). In addition, many of the markers are illustrated in Plates 1 through 14.

Biostratigraphic investigations were conducted in the light microscope with $1250 \times$ magnification. Each slide was observed in crosspolarized and phase-contrast light to detect species more discernible under each illumination. Most samples were observed on three to four separate occasions for an average of 10-20 min. A greater amount of time was devoted to samples close to the ends of species' ranges and especially near zonal boundaries, where sometimes samples were observed for several hours. The relative abundance of nannofossils was determined in the following fashion: a species was termed abundant if, on average, more than 10 specimens could be observed in a field of view at $1250 \times$ magnification; common if $1-9$ specimens could be observed in each field; few if 1-9 specimens could be observed in every 10 fields of view; and rare if, on average, 1 specimen could not be observed in 10 fields. Scanning electron microscopy, using a Leica Stereoscan 440 SEM in the Geology Department of the University of North Carolina, Chapel Hill, was used to document the preservation of assemblages and clarify particular taxonomic concepts.

\section{RESULTS}

A list of the calcareous nannofossil taxa observed is given in the Appendix, along with detailed information related to identification and differential diagnosis. Plates 1 through 14 illustrate significant markers and other taxa observed in Holes $865 \mathrm{~B}$ and $865 \mathrm{C}$. Range charts showing the distribution of all species observed are presented in Tables 1 and 2 (back pocket).

\section{Preservation}

Calcareous nannofossil preservation is uniformly moderate throughout the Paleogene section recovered in Holes $865 \mathrm{~B}$ and $865 \mathrm{C}$. Most samples show signs of slight etching and moderate overgrowth. Etching has removed delicate features from several species, for example the central area of many Toweius or the net of most Reticulofenestra. Overgrowth has masked whole specimens, making it difficult to distinguish consistently between species of Nannotetrina, for example, to positively identify species of Tribrachiatus, or to discern features such as the knobs and ridges of discoasters. In terms of the parameters described by Roth (1978), most samples lie between E-1 and E-2 and near $\mathrm{O}-2$. A few samples distributed randomly through the section have good preservation. In addition, one interval between 79 and $83 \mathrm{~m}$ in both holes is characterized by slightly poorer preservation, dramatically lower abundances, and large amounts of bladed calcite crystals of an unknown origin. The paucity of nannofossils in this interval significantly reduces the precision with which several events can be determined. Examples include the last occurrence (LO) of Toweius eminens and the first occurrence (FO) of Chiasmolithus grandis.

\section{Biostratigraphy}

In both holes, the Paleogene sequence underlies a thin, 15-m veneer of lower Miocene and Quaternary sediments. A thin, 2- to 3-m interval of late Oligocene age (Zone CP19) occurs in Hole 865C, but not in Hole 865B (Sager, Winterer, Firth, et al., 1993). It appears that a minor unconformity lies at the Eocene/Oligocene boundary in both Holes $865 \mathrm{~B}$ and $865 \mathrm{C}$; this is indicated by the clustering of three events, the LOs of Calcidiscus protoannulus, Discoaster barbadiensis, and D. saipanensis at the same level in both holes. The former event is separated from the latter two events by $1.5 \mathrm{~m} . \mathrm{y}$. in South Atlantic DSDP sites (Backman, 1987). The largely continuous part of the Paleogene section ranges in age from late Eocene to early Paleocene. A minor unconformity occurs in the uppermost lower Eocene correlating to parts of Zones CP11 and CP12. The lower middle Eocene interval was deposited at low sedimentation rates.

\section{Application of Standard Paleogene Zonations}

The standard zonation of Bukry (1973, 1975b), emended by Okada and Bukry (1980), was developed in low-latitude oceanic sections. Hence, this has been the scheme that was primarily applied here. In the following, we refer to the combination of these schemes as OB80. In general, OB80 was not as applicable at Site 865 as might be expected. Several of the important boundary marker taxa were not observed. The zonation of Martini (1971) (referred to in the following as M71), on the other hand, was established in land sequences largely from the continents. This scheme was only slightly less applicable than OB80. The correlation of the OB80 and M71 zones in Holes $865 \mathrm{~B}$ and $865 \mathrm{C}$ are illustrated in Figures 4 through 8 and compiled in Table 3 . In the following, we discuss the application of the OB80 scheme at Site 865 . The intervals given for the ranges of zonal units are based on the suite of samples observed (Tables 1-2, back pocket).

\section{Application of the Bukry $(1973,1975 b)$ and Okada and Bukry (1980) Zonations}

\section{CP16 Helicosphaera reticulata Zone}

Definition: Interval from the LOs of Discoaster barbadiensis and/or $D$. saipanensis to the LOs of Reticulofenestra umbilicus and/or $R$. hillae. Age: early Oligocene

Hole 865B: $143-865 \mathrm{~B}-3 \mathrm{H}-1,70 \mathrm{~cm}$, to $-2 \mathrm{H}-5,115 \mathrm{~cm}$

Hole 865C: $143-865 \mathrm{C}-3 \mathrm{H}-5,10 \mathrm{~cm}$, to $-3 \mathrm{H}-1,80 \mathrm{~cm}$ 
Comments: The upper boundary of this zone lies at an unconformity in both holes. In Hole 865B, this zone is overlain by lower Miocene sediments (Zone $\mathrm{CN1}$ ). In Hole $865 \mathrm{C}$, this zone is overlain by upper Oligocene sediments (Zone CP19). The exact locations of these unconformities have not been determined.

\section{CP16a Coccolithus (Ericsonia) subdistichus(a) Subzone}

Definition: Interval from the LOs of Discoaster barbadiensis and/or $D$. saipanensis to the LO of the acme of E. subdisticha

Age: early Oligocene

Hole 865B: $143-865 \mathrm{~B}-3 \mathrm{H}-1,70 \mathrm{~cm}$, to $-2 \mathrm{H}-5,115 \mathrm{~cm}$

Hole 865C: $143-865 \mathrm{C}-3 \mathrm{H}-5,10 \mathrm{~cm}$, to $-3 \mathrm{H}-1,80 \mathrm{~cm}$

Comments: The upper limit of this subzone is defined by the top of the acme of the nominate taxon. This taxon is uncommon in the interval of interest in both holes. Therefore, it is likely that the top of Subzone CP16a lies at the above-mentioned unconformity. See comments for Zone CP16.

\section{CP15 Discoaster barbadiensis Zone}

Definition: Interval from the LO of Chiasmolithus grandis to the LOs of $D$. barbadiensis and/or D. saipanensis

Age: late Eocene

Hole 865B: $143-865 \mathrm{~B}-3 \mathrm{H}-1,132 \mathrm{~cm}$, to $-3 \mathrm{H}-1,70 \mathrm{~cm}$

Hole 865C: $143-865 \mathrm{C}-3 \mathrm{H}-6,10 \mathrm{~cm}$, to $-3 \mathrm{H}-5,10 \mathrm{~cm}$

Comments: The LO of $C$. grandis is a difficult event to determine precisely as this species occurs rarely and (in Hole 865B) sporadically in the upper part of its range (Tables 1-2). It is difficult to rule out the possibility that the scattered occurrences above the continuous part of the range of $C$. grandis (above Sample 143-865B-3H-CC) are a result of reworking. We note that the overlap in the range of $C$. grandis and $C$. oamaruensis, as observed in Hole $865 \mathrm{C}$, has only been observed in one or two sections, mostly from high latitudes. A tropical section is an unlikely place to observe such an overlap, as the range of both species should be curtailed (see Wei and Wise, 1989). As mentioned above, it appears that an unconformity may lie between Zones $\mathrm{CP} 15$ and $\mathrm{CP} 16$, including the Eocene/Oligocene boundary

\section{$C P 15 b$ Isthmolithus recurvus Subzone}

Definition: Interval from the FO of $L$. recurvus to the LOs of $D$. barbadiensis and/or D. saipanensis

Age: late Eocene

Comments: This subzone cannot be defined at Site 865, as I. recurvus does not occur.

\section{CP15a Chiasmolithus oamaruensis Subzone}

Definition: Interval from the LO of $C$. grandis to the FO of $I$. recurvus

Age: late Eocene

Comments: This subzone cannot be defined at Site 865, as I. recurvus does not occur.

\section{CP14 Reticulofenestra umbilicus Zone}

Definition: Interval from the FO of $R$. umbilicus to the LO of $C$. grandis Age: middle Eocene

Hole 865B: $143-865 \mathrm{~B}-6 \mathrm{H}-1,81 \mathrm{~cm}$, to $-3 \mathrm{H}-1,132 \mathrm{~cm}$

Hole 865C: $143-865 \mathrm{C}-6 \mathrm{H}-\mathrm{CC}$ to $-3 \mathrm{H}-6,10 \mathrm{~cm}$

Comments: Reticulofenestra umbilicus is differentiated from closely related species of Reticulofenestra by size (see Appendix). As is the tendency for events based on such size increases, determination of the FO of $R$. umbilicus can vary dramatically if one takes into account isolated specimens of the correct size, or if one uses the level at which this size becomes more frequent (e.g., Backman and Hermelin, 1986). For example, one specimen of R. umbilicus was observed in Sample 143-865C-7H-1, $148 \mathrm{~cm}$, but this taxon does not occur consistently below Sample 143-865C-6H-CC. Because the former level lies below the LO of Chiasmolithus gigas, the event that defines the base of underlying Subzone CP13c, we have placed the base of this zone at the latter horizon. See description of Zone CP15 for comments about the LO of $C$. grandis.

\section{CP14b Discoaster saipanensis Subzone}

Definition: Interval from the LOs of Chiasmolithus solitus and/or D. bifax to the $\mathrm{LO}$ of $C$. grandis
Age: middle Eocene

Hole 865B: $143-865 \mathrm{~B}-4 \mathrm{H}-2,40 \mathrm{~cm}$, to $-3 \mathrm{H}-1,132 \mathrm{~cm}$

Hole 865C: $143-865 \mathrm{C}-4 \mathrm{H}-6,10 \mathrm{~cm}$, to $-3 \mathrm{H}-6,10 \mathrm{~cm}$

Comments: This subzone can be determined precisely in both holes based on the ranges of the species of Chiasmolithus. See comments for Zone CP15. No unambiguous specimens of Discoaster bifax were observed.

\section{CP14a Discoaster bifax Subzone}

Definition: Interval from the FOs of R. umbilicus and/or D. bifax to the LOs of $C$. solitus and/or D. bifax

Age: middle Eocene

Hole 865B: $143-865 \mathrm{~B}-6 \mathrm{H}-1,81 \mathrm{~cm}$, to $-4 \mathrm{H}-2,40 \mathrm{~cm}$

Hole 865C: $143-865 \mathrm{C}-6 \mathrm{H}-\mathrm{CC}$ to $-4 \mathrm{H}-6,10 \mathrm{~cm}$

Comments: See comments above for determination of the base of Zone CP14. The top of this subzone can be determined precisely in both holes.

\section{CP13 Nannotetrina quadrata Zone}

Definition: Interval from the FO of $N$. quadrata ( $N$. fulgens) and/or the LO of Rhabdosphaera inflata to the FO of $R$. umbilicus

Age: middle Eocene

Hole 865B: $143-865 \mathrm{~B}-8 \mathrm{H}-6,20 \mathrm{~cm}$, to $-6 \mathrm{H}-1,81 \mathrm{~cm}$

Hole 865C: $143-865 \mathrm{C}-9 \mathrm{H}-3,10 \mathrm{~cm}$, to $-6 \mathrm{H}-\mathrm{CC}$

Comments: This zone is expanded at Site 865 , accounting for 26 and $27 \mathrm{~m}$ of section in Holes $865 \mathrm{~B}$ and $865 \mathrm{C}$, respectively. We are less than confident about the precision with which the base of this zone has been established for two reasons: (1) $R$. inflata is taxonomically distinct, although it is very rare in both holes and has a short range; and (2) the genus Nannotetrina is more common and has a longer range than $R$. inflata, although it is difficult to subdivide consistently (see Appendix), especially at Site 865, as many specimens are overgrown. Numerous specimens observed in Zone CP12 have a simple cross-structure and are included in Nannotetrina sp.; we differentiate $N$. fulgens from these specimens based on the slight offset between opposing elements of the cross. The specimens we include in this taxon are smaller than those previously described (e.g., Romein, 1979; see Appendix for complete discussion). As determined, the FO of $N$. fulgens correlates with the LO of $R$. inflata.

\section{CP13c Coccolithus staurion Subzone}

Definition: Interval from the LO of Chiasmolithus gigas to the FOs of $R$. umbilicus and/or D. bifax

Age: middle Eocene

Hole 865B: $143-865 \mathrm{~B}-6 \mathrm{H}-2,73 \mathrm{~cm}$, to $-6 \mathrm{H}-1,81 \mathrm{~cm}$

Hole 865C: $143-865 \mathrm{C}-7 \mathrm{H}-1,10 \mathrm{~cm}$, to $-6 \mathrm{H}-\mathrm{CC}$

Comments: We observed specimens of $C$. gigas in the early and late parts of its range with a central cross of reduced size, a morphotype that has not been illustrated. Even when this form is included in the definition of $C$. gigas, this subzone is of reduced thickness in both holes.

\section{CP13b Chiasmolithus gigas Subzone}

Definition: Total range of $C$. gigas

Age: middle Eocene

Hole 865B: $143-865 \mathrm{~B}-8 \mathrm{H}-2,70 \mathrm{~cm}$, to $-6 \mathrm{H}-2,73 \mathrm{~cm}$

Hole 865C: $143-865 \mathrm{C}-8 \mathrm{H}-5,10 \mathrm{~cm}$, to $-7 \mathrm{H}-1,10 \mathrm{~cm}$

Comments: See comments for Subzone CP13c above.

\section{CP13a Discoaster strictus Subzone}

Definition: Interval from the FO of $N$. fulgens and/or the LO of $R$. inflata to the $\mathrm{FO}$ of $C$. gigas

Age: middle Eocene

Hole 865B: $143-865 \mathrm{~B}-8 \mathrm{H}-6,20 \mathrm{~cm}$, to $-8 \mathrm{H}-2,70 \mathrm{~cm}$

Hole 865C: $143-865 \mathrm{C}-9 \mathrm{H}-3,10 \mathrm{~cm}$, to $-8 \mathrm{H}-5,10 \mathrm{~cm}$

Comments: See comments for Zone CP13 and Subzone CP13c above.

\section{CP12 Discoaster sublodoensis Zone}

Definition: Interval from the FO of $D$. sublodoensis to the FO of $N$. fulgens and/or the LO of $R$. inflata

Age: early to middle Eocene

Hole 865B: $143-865 \mathrm{~B}-9 \mathrm{H}-4,10 \mathrm{~cm}$, to $-8 \mathrm{H}-6,20 \mathrm{~cm}$

Hole 865C: $143-865 \mathrm{C}-10 \mathrm{H}-1,10 \mathrm{~cm}$, to $-9 \mathrm{H}-3,10 \mathrm{~cm}$

Comments: This zone is of reduced thickness at Site 865 and represents only $6 \mathrm{~m}$ of section. This may result from the relatively strict species concepts 
Table 3. Meter levels of nannofossil biohorizons in Holes 865B and 865C.

\begin{tabular}{|c|c|c|c|c|c|c|}
\hline \multirow[b]{2}{*}{ Event } & Hole & $5 \mathrm{~B}$ & Hole & $65 \mathrm{C}$ & & \\
\hline & $\begin{array}{l}\text { Sample } \\
(\mathrm{cm})\end{array}$ & $\begin{array}{l}\text { Depth } \\
\text { (mbsf) }\end{array}$ & $\begin{array}{c}\text { Sample } \\
(\mathrm{cm})\end{array}$ & $\begin{array}{l}\text { Depth } \\
\text { (mbsf) }\end{array}$ & OB80 & M71 \\
\hline FAD E. subdisticha & $2 \mathrm{H}-\mathrm{CC}$ & 17.90 & $3 \mathrm{H}-4,10$ & 17.40 & & \\
\hline LAD $R$, reticulata & $2 \mathrm{H}-\mathrm{CC}$ & 17.90 & $3 \mathrm{H}-4,10$ & 17.40 & & \\
\hline LAD S. spiniger & $3 \mathrm{H}-1,20$ & 18.20 & $3 \mathrm{H}-4,80$ & 18.10 & & \\
\hline LAD C. protoannulus & $3 \mathrm{H}-1,70$ & 18.70 & $3 \mathrm{H}-5,10$ & 18.90 & & \\
\hline LAD D. barbadiensis & $3 \mathrm{H}-1,70$ & 18.70 & $3 \mathrm{H}-5,10$ & 18.90 & CP16 & NP21 \\
\hline LAD D. saipanensis & $3 \mathrm{H}-1,70$ & 18.70 & $3 \mathrm{H}-5,10$ & 18.90 & CP16 & NP21 \\
\hline LAD $S$, radians & $3 \mathrm{H}-1,132$ & 19.32 & $3 \mathrm{H}-5,10$ & 18.90 & & \\
\hline FAD $H$. reticulata & $3 \mathrm{H}-1,132$ & 19.32 & $3 \mathrm{H}-5,10$ & 18.90 & & \\
\hline LAD C. grandis & $3 \mathrm{H}-1,132$ & 19.32 & $3 \mathrm{H}-6,10$ & 20.40 & CP15 & \\
\hline FAD $S$. predistentus & $3 \mathrm{H}-2,96$ & 20.46 & $3 \mathrm{H}-\mathrm{CC}$ & 21.10 & & \\
\hline FAD C. oamaruensis & - & - & $4 \mathrm{H}-1,10$ & 22.40 & & NP18 \\
\hline LAD C. dela & $3 \mathrm{H}-6,68$ & 26.19 & $4 \mathrm{H}-4,10$ & 26.90 & & \\
\hline FAD $R$. hillae & $3 \mathrm{H}-\mathrm{CC}$ & 26.50 & $4 \mathrm{H}-5,10$ & 28.40 & & \\
\hline FAD D. nodifer & $3 \mathrm{H}-\mathrm{CC}$ & 26.50 & $5 \mathrm{H}-1,100$ & 32.80 & & \\
\hline FAD $R$. reticulata & $4 \mathrm{H}-1,16$ & 27.66 & $4 \mathrm{H}-5,10$ & 28.40 & & \\
\hline FAD D. bisectus & $4 \mathrm{H}-2,40$ & 29.40 & $4 \mathrm{H}-6,10$ & 29.90 & & \\
\hline LAD C. solitus & $4 \mathrm{H}-2,40$ & 29.40 & $4 \mathrm{H}-6,10$ & 29.90 & CP14b & NP17 \\
\hline LAD S. obtusus & $4 \mathrm{H}-2,40$ & 29.40 & $4 \mathrm{H}-6,10$ & 29.90 & & \\
\hline LAD $S$. furcatolithoides & $4 \mathrm{H}-2,40$ & 29.40 & $4 \mathrm{H}-\mathrm{CC}$ & 30.70 & & \\
\hline LAD C. nitidus & $4 \mathrm{H}-3,91$ & 31.41 & $4 \mathrm{H}-6,10$ & 29.90 & & \\
\hline LAD S. orphanknollensis & $4 \mathrm{H}-3,91$ & 31.41 & $5 \mathrm{H}-1,10$ & 31.90 & & \\
\hline LAD $T$. inversus & $4 \mathrm{H}-3,91$ & 31.41 & $5 \mathrm{H}-1,100$ & 32.80 & & \\
\hline FAD D. scrippsae & $4 \mathrm{H}-4,107$ & 33.07 & $5 \mathrm{H}-1,10$ & 31.90 & & \\
\hline FAD $S$. obtusus & $4 \mathrm{H}-\mathrm{CC}$ & 35.00 & $5 \mathrm{H}-4,100$ & 37.30 & & \\
\hline LAD C. medius & $5 \mathrm{H}-1.70$ & 37.70 & $5 \mathrm{H}-4,100$ & 37.30 & & \\
\hline LAD C. vanheckii & $5 \mathrm{H}-2,70$ & 39.20 & $5 \mathrm{H}-3,126$ & 36.16 & & \\
\hline FAD $S$. pseudoradians & $5 \mathrm{H}-3,70$ & 40.70 & $6 \mathrm{H}-1,10$ & 41.40 & & NP20 \\
\hline FAD $H$. heezenii & $5 \mathrm{H}-3,70$ & 40.70 & $6 \mathrm{H}-1,10$ & 41.40 & & \\
\hline LAD $N$, fulgens & $5 \mathrm{H}-6,54$ & 44.54 & $6 \mathrm{H}-1,75$ & 42.05 & & \\
\hline FAD $R$. umbilicus & $6 \mathrm{H}-1,81$ & 47.31 & $6 \mathrm{H}-\mathrm{CC}$ & $46.00^{\mathrm{a}}$ & CP14a & \\
\hline LAD C gigas & $6 \mathrm{H}-2,73$ & 48.73 & $7 \mathrm{H}-1,10$ & $50.90^{a}$ & $\mathrm{CP} 13 \mathrm{c}$ & \\
\hline LAD L. rotundus & $7 \mathrm{H}-1,118$ & 57.18 & $7 \mathrm{H}-3,100$ & 54.80 & & \\
\hline FAD $H$. dinesenii & $7 \mathrm{H}-1,118$ & 57.18 & $7 \mathrm{H}-4,10$ & 55.40 & & \\
\hline FAD B. serraculoides & $7 \mathrm{H}-3,68$ & 59.69 & $7 \mathrm{H}-5,100$ & 57.80 & & \\
\hline FAD C. medius & $7 \mathrm{H}-4,68$ & 61.19 & $8 \mathrm{H}-2,10$ & 61.90 & & \\
\hline LAD L. mochloporus & $7 \mathrm{H}-6,76$ & 63.76 & $8 \mathrm{H}-2,98$ & 62.78 & & \\
\hline LAD S. stellatus & $7 \mathrm{H}-6,76$ & 63.76 & $8 \mathrm{H}-3,98$ & 64.28 & & \\
\hline FAD S. furcatolithoides & $7 \mathrm{H}-\mathrm{CC}$ & 64.04 & $8 \mathrm{H}-3,10$ & 63.40 & & \\
\hline LAD C. cribellum & $8 \mathrm{H}-1,89$ & 66.39 & $8 \mathrm{H}-3,98$ & 64.28 & & \\
\hline FAD C. gigas & $8 \mathrm{H}-2,70$ & 67.70 & $8 \mathrm{H}-5,10$ & 66.40 & CP13b & \\
\hline LAD E. lajollaensis & $8 \mathrm{H}-2,70$ & 67.70 & $8 \mathrm{H}-6,82$ & 68.62 & & \\
\hline FAD D. nodifer minor & $8 \mathrm{H}-3,70$ & 69.20 & $8 \mathrm{H}-6,82$ & 68.62 & & \\
\hline FAD $C$, vanheckii & $8 \mathrm{H}-3,70$ & 69.20 & $8 \mathrm{H}-\mathrm{CC}$ & 68.80 & & \\
\hline LAD Neocrepidolithus sp. & $8 \mathrm{H}-4,67$ & 70.67 & $8 \mathrm{H}-3,98$ & 64.28 & & \\
\hline FAD L. rotundus & $8 \mathrm{H}-4,67$ & 70.67 & $9 \mathrm{H}-1,20$ & 70.00 & & \\
\hline LAD S. editus & $8 \mathrm{H}-5,70$ & 72.20 & $9 \mathrm{H}-1,90$ & 70.70 & & \\
\hline LAD D. sublodoensis & $8 \mathrm{H}-5,70$ & 72.20 & $9 \mathrm{H}-2,10$ & 71.40 & & \\
\hline FAD $S$. orphanknollensis & $8 \mathrm{H}-6,20$ & 73.20 & $9 \mathrm{H}-2,100$ & 72.30 & & \\
\hline FAD $S$, spiniger & $8 \mathrm{H}-6,20$ & 73.20 & $9 \mathrm{H}-3,10$ & 72.90 & & \\
\hline FAD $N$. fulgens & $8 \mathrm{H}-6,20$ & 73.20 & $9 \mathrm{H}-3,10$ & 72.90 & CP13a & NP15 \\
\hline $\mathrm{LAD} R$. inflata & $8 \mathrm{H}-6,20$ & 73.20 & $9 \mathrm{H}-3,10$ & 72.90 & CP13a & \\
\hline FAD $S$. stellatus & $8 \mathrm{H}-6,20$ & 73.20 & $9 \mathrm{H}-3,10$ & 72.90 & & \\
\hline FAD D. saipanensis & $8 \mathrm{H}-\mathrm{CC}$ & $74.00^{\mathrm{a}}$ & $9 \mathrm{H}-3,90$ & 73.70 & & \\
\hline FAD $R$. inflata & $8 \mathrm{H}-\mathrm{CC}$ & $74.00^{\mathrm{a}}$ & $9 \mathrm{H}-4,10$ & 74.40 & $\mathrm{CP} 12 \mathrm{~b}$ & \\
\hline LAD D. lodoensis & $8 \mathrm{H}-\mathrm{CC}$ & $74.00^{a}$ & $9 \mathrm{H}-4,10$ & 74.40 & & \\
\hline LAD $T$. gammation & $9 \mathrm{H}-1,13$ & 75.13 & $9 \mathrm{H}-4,100$ & 75.30 & & \\
\hline LAD C. crassus & $9 \mathrm{H}-1,113$ & 76.13 & $9 \mathrm{H}-5,100$ & 76.80 & & \\
\hline FAD Cyclicargolithus sp. & $9 \mathrm{H}-1,113$ & 76.13 & $9 \mathrm{H}-5,100$ & 76.80 & & \\
\hline FAD E. insolita & $9 \mathrm{H}-2,20$ & 76.70 & $9 \mathrm{H}-6,100$ & 78.30 & & \\
\hline LAD $L$, nascens & $9 \mathrm{H}-2,100$ & 77.50 & $9 \mathrm{H}-6,10$ & 77.40 & & \\
\hline FAD $T$. inversus & $9 \mathrm{H}-2,100$ & 77.50 & $9 \mathrm{H}-6,100$ & 78.30 & & \\
\hline FAD C. grandis & $9 \mathrm{H}-4,10$ & 79.60 & $10 \mathrm{H}-1,10$ & 79.40 & & \\
\hline FAD D. sublodoensis & $9 \mathrm{H}-4,10$ & 79.60 & $10 \mathrm{H}-1,10$ & 79.40 & CP12a & NP14 \\
\hline LAD $T$. orthostylus & $9 \mathrm{H}-4,10$ & 79.60 & $10 \mathrm{H}-1,10$ & 79.40 & & NP13 \\
\hline LAD S. conspicuus & $9 \mathrm{H}-4,10$ & 79.60 & $10 \mathrm{H}-1,10$ & 79.40 & & \\
\hline FAD $H$. lophota & $9 \mathrm{H}-4,100$ & 80.50 & $9 \mathrm{H}-6,100$ & 78.30 & & \\
\hline LAD T. callosus & $9 \mathrm{H}-4,100$ & 80.50 & $9 \mathrm{H}-\mathrm{CC}$ & $78.80^{\mathrm{a}}$ & & \\
\hline FAD Nannotetrina sp. & $9 \mathrm{H}-4,100$ & 80.50 & $9 \mathrm{H}-\mathrm{CC}$ & $78.80^{\mathrm{a}}$ & & \\
\hline FAD $T$. gammation & $9 \mathrm{H}-5,70$ & 81.70 & $10 \mathrm{H}-3,100$ & 83.30 & & \\
\hline FAD D. deflandrei & $9 \mathrm{H}-6,20$ & 82.70 & $10 \mathrm{H}-3,10$ & 82.40 & & \\
\hline LAD $C$. eodela & $9 \mathrm{H}-6,20$ & 82.70 & $10 \mathrm{H}-3,10$ & 82.40 & & \\
\hline FAD C. nitidus & $9 \mathrm{H}-6.20$ & 82.70 & $10 \mathrm{H}-4,122$ & 85.02 & & \\
\hline LAD $T$. eminens & $9 \mathrm{H}-6,70$ & 83.20 & $10 \mathrm{H}-1,100$ & 80.30 & & \\
\hline FAD $H$. seminulum & $9 \mathrm{H}-6,70$ & 83.20 & $10 \mathrm{H}-3,10$ & 82.40 & & \\
\hline LAD T. pertusus & $9 \mathrm{H}-6,70$ & 83.20 & $10 \mathrm{H}-3,10$ & 82.40 & & \\
\hline FAD L mochloporus & $9 \mathrm{H}-6,70$ & 83.20 & $10 \mathrm{H}-3,10$ & 82.40 & & \\
\hline FAD C . crassus & $9 \mathrm{H}-6,70$ & 83.20 & $10 \mathrm{H}-3,10$ & 82.40 & CP11 & \\
\hline FAD E. lajollaensis & $9 \mathrm{H}-\mathrm{CC}$ & 83.60 & $10 \mathrm{H}-3,100$ & 83.30 & & \\
\hline LAD N. protenus & $10 \mathrm{H}-1,23$ & 84.73 & $10 \mathrm{H}-3,10$ & 82.40 & & \\
\hline LAD E. macellus & $10 \mathrm{H}-1,23$ & 84.73 & $10 \mathrm{H}-3,100$ & 83.30 & & \\
\hline FAD C. cribellum & $10 \mathrm{H}-1,23$ & 84.73 & $10 \mathrm{H}-3,100$ & 83.30 & & \\
\hline FAD $R$. dictyoda & $10 \mathrm{H}-2,112$ & 87.22 & $10 \mathrm{H}-4,10$ & 83.90 & & \\
\hline LAD $S$, anarrhopus & $10 \mathrm{H}-2,112$ & 87.22 & $10 \mathrm{H}-5,134$ & 86.66 & & \\
\hline LAD D. multiradiatus & $10 \mathrm{H}-3,60$ & 88.10 & $10 \mathrm{H}-6,10$ & 86.90 & & \\
\hline LAD Cruciplacolithus sp. & $10 \mathrm{H}-3,120$ & 88.70 & $10 \mathrm{H}-6,10$ & 86.90 & & \\
\hline FAD D. lodoensis & $10 \mathrm{H}-4,60$ & 89.60 & $10 \mathrm{H}-\mathrm{CC}$ & $87.40^{a}$ & CP10 & NP12 \\
\hline FAD E. formosa & $10 \mathrm{H}-4,60$ & 89.60 & $11 \mathrm{H}-1,140$ & 90.24 & & \\
\hline
\end{tabular}


Table 3 (continued).

\begin{tabular}{|c|c|c|c|c|c|c|}
\hline \multirow[b]{2}{*}{ EVENT } & \multicolumn{2}{|c|}{ Hole 865B } & \multicolumn{2}{|c|}{ Hole $865 \mathrm{C}$} & \multirow[b]{2}{*}{ OB80 } & \multirow[b]{2}{*}{ M71 } \\
\hline & $\begin{array}{c}\text { Sample } \\
(\mathrm{cm})\end{array}$ & $\begin{array}{l}\text { Depth } \\
\text { (mbsf) }\end{array}$ & $\begin{array}{c}\text { Sample } \\
(\mathrm{cm})\end{array}$ & $\begin{array}{l}\text { Depth } \\
\text { (mbsf) }\end{array}$ & & \\
\hline FAD $N$. dubius & $10 \mathrm{H}-4,120$ & 90.20 & $11 \mathrm{H}-1,140$ & 90.24 & & \\
\hline FAD $S$, radians & $10 \mathrm{H}-5,4$ & 90.54 & $11 \mathrm{H}-2,20$ & 90.50 & & \\
\hline FAD C. protoannulus & $10 \mathrm{H}-5,4$ & 90.54 & $11 \mathrm{H}-2,20$ & 90.50 & & \\
\hline LAD $T$. contortus? & $10 \mathrm{H}-5,111$ & 91.61 & $11 \mathrm{H}-2,134$ & 91.64 & CP9b & NP11 \\
\hline FAD $S$. conspicuus & $10 \mathrm{H}-\mathrm{CC}$ & 91.80 & $11 \mathrm{H}-2,80$ & 91.10 & & \\
\hline FAD T. orthostylus & $10 \mathrm{H}-\mathrm{CC}$ & $91.80^{\mathrm{a}}$ & $11 \mathrm{H}-4,20$ & 93.50 & & \\
\hline LAD N. junctus & $11 \mathrm{H}-1,20$ & 94.20 & $11 \mathrm{H}-3,20$ & 92.00 & & \\
\hline LAD T. bramlettei? & $11 \mathrm{H}-1,20$ & $94.20^{\mathrm{a}}$ & $11 \mathrm{H}-3,80$ & 92.60 & & \\
\hline FAD $S$, editus & $11 \mathrm{H}-1,20$ & 94.20 & $11 \mathrm{H}-4,80$ & 94.10 & & \\
\hline LAD C. bidens & $11 \mathrm{H}-1,70$ & 94.70 & $11 \mathrm{H}-3,80$ & 92.60 & & \\
\hline LAD D. lenticularis & $11 \mathrm{H}-1,70$ & 94.70 & $11 \mathrm{H}-3,80$ & 92.60 & & \\
\hline LAD P. sigmoides & $11 \mathrm{H}-1,70$ & 94.70 & $11 \mathrm{H}-3,140$ & 93.20 & & \\
\hline LAD C. asymmetricus & $11 \mathrm{H}-1,70$ & 94.70 & $11 \mathrm{H}-3,140$ & 93.20 & & \\
\hline FAD D. barbadiensis & $11 \mathrm{H}-1,129$ & 95.29 & $11 \mathrm{H}-4,20$ & 93.60 & & \\
\hline FAD $T$. callosus & $11 \mathrm{H}-1,129$ & 95.29 & $11 \mathrm{H}-4,140$ & 94.70 & & \\
\hline FAD $T$. contortus? & $11 \mathrm{H}-1,129$ & 95.29 & $11 \mathrm{H}-5,80$ & 95.60 & & \\
\hline LAD $N$. distentus & $11 \mathrm{H}-2,20$ & 95.70 & $11 \mathrm{H}-6,80$ & 97.10 & & \\
\hline LAD N. bukryi & $11 \mathrm{H}-2,70$ & 96.20 & $11 \mathrm{H}-6,80$ & 97.10 & & \\
\hline LAD N. perfectus & $11 \mathrm{H}-4,110$ & 99.60 & $11 \mathrm{H}-4,140$ & 94.70 & & \\
\hline LAD P. bisulcus & $11 \mathrm{H}-4,110$ & 99.60 & $12 \mathrm{H}-2,20$ & 100.00 & & \\
\hline FAD $P$. larvalis & $11 \mathrm{H}-5,20$ & 100.20 & $12 \mathrm{H}-1,111$ & 99.40 & & \\
\hline LAD E. distichus & $11 \mathrm{H}-6,20$ & 101.70 & $11 \mathrm{H}-6,20$ & 96.50 & & \\
\hline FAD $T$. bramlettei? & $11 \mathrm{H}-6,70$ & 102.20 & $12 \mathrm{H}-3,138$ & 102.68 & CP9a & NP10 \\
\hline LAD Fasciculithus spp. & $11 \mathrm{H}-6,70$ & 102.20 & $12 \mathrm{H}-2,110$ & 100.90 & & \\
\hline LAD F. tympaniformis & $11 \mathrm{H}-6,70$ & 102.20 & $12 \mathrm{H}-2,110$ & 100.90 & & \\
\hline FAD C. eograndis & $11 \mathrm{H}-\mathrm{CC}, 2$ & $102.50^{\mathrm{a}}$ & $12 \mathrm{H}-3,50$ & 101.80 & & \\
\hline FAD Z bijugatus & $11 \mathrm{H}-\mathrm{CC}, 2$ & $102.50^{\mathrm{a}}$ & $12 \mathrm{H}-4,10$ & 102.90 & & \\
\hline LAD C. temuis & $12 \mathrm{H}-1,4$ & $103.54^{a}$ & $12 \mathrm{H}-3,110$ & 102.40 & & \\
\hline LAD D. mohleri & $12 \mathrm{H}-1,4$ & $103.54^{\mathrm{a}}$ & $12 \mathrm{H}-3,110$ & 102.40 & & \\
\hline FAD Ellipsolithus sp. & $12 \mathrm{H}-1,111$ & 104.51 & $12 \mathrm{H}-5,20$ & 104.50 & & \\
\hline LAD $E$. robusta & $12 \mathrm{H}-2,20$ & 105.20 & $12 \mathrm{H}-4,50$ & 103.30 & & \\
\hline FAD $P$. prelarvalis & $12 \mathrm{H}-2,120$ & 106.20 & $12 \mathrm{H}-6,20$ & 106.00 & & \\
\hline LAD C. frequens & $12 \mathrm{H}-4,20$ & 108.20 & $13 \mathrm{H}-1,10$ & 107.90 & & \\
\hline FAD $F$, aubertae & $12 \mathrm{H}-4,100$ & 108.70 & $13 \mathrm{H}-1,10$ & 107.90 & & \\
\hline FAD L. nascens & $12 \mathrm{H}-6,20$ & 111.20 & $13 \mathrm{H}-1,80$ & 108.60 & & \\
\hline FAD $C$. dela & $12 \mathrm{H}-6,70$ & 111.70 & $13 \mathrm{H}-1,80$ & 108.60 & & \\
\hline FAD D. lenticularis & $13 \mathrm{H}-1,21$ & 113.21 & $13 \mathrm{H}-4,10$ & 112.40 & & \\
\hline FAD N. junctus & $13 \mathrm{H}-1,21$ & 113.21 & $13 \mathrm{H}-5,10$ & 113.90 & & \\
\hline FAD $F$. lilianae & $13 \mathrm{H}-2,17$ & 114.67 & $13 \mathrm{H}-6,80$ & 116.10 & & \\
\hline FAD D. multiradiatus & $13 \mathrm{H}-3,21$ & 116.21 & $13 \mathrm{H}-5,80$ & 114.60 & CP8 & NP9 \\
\hline LAD Prinsius spp. & $13 \mathrm{H}-4,100$ & 118.50 & $14 \mathrm{H}-1,10$ & 117.40 & & \\
\hline FAD D. nobilis & $13 \mathrm{H}-5,100$ & 120.00 & $14 \mathrm{H}-1,10$ & 117.40 & CP7 & \\
\hline LAD H. kleinpellii & $14 \mathrm{H}-1,20$ & 122.70 & $14 \mathrm{H}-\mathrm{CC}$ & 121.70 & & \\
\hline FAD C. eodela & $14 \mathrm{H}-1,116$ & 123.66 & $14 \mathrm{H}-\mathrm{CC}$ & $121.70^{a}$ & CP8b & \\
\hline FAD D. mohleri & $14 \mathrm{H}-3,25$ & 125.75 & $14 \mathrm{H}-\mathrm{CC}$ & $121.70^{\mathrm{a}}$ & CP6 & NP7 \\
\hline FAD E. macellus & $14 \mathrm{H}-3,93$ & 126.43 & $14 \mathrm{H}-\mathrm{CC}$ & $121.70^{a}$ & & \\
\hline FAD N. distentus & $14 \mathrm{H}-4,23$ & 127.23 & $14 \mathrm{H}-3,80$ & 121.10 & & \\
\hline LAD C. danicus & $14 \mathrm{H}-4,109$ & 128.09 & $15 \mathrm{H}-1,10$ & 126.90 & & \\
\hline FAD N. bukryi & $14 \mathrm{H}-5,22$ & 128.72 & $14 \mathrm{H}-\mathrm{CC}$ & $121.70^{2}$ & & \\
\hline FAD Neocrepidolithus sp. & $14 \mathrm{H}-5,22$ & 128.72 & $14 \mathrm{H}-\mathrm{CC}$ & $121.70^{2}$ & & \\
\hline LAD $F$. pileatus & $14 \mathrm{H}-5,22$ & 128.72 & $14 \mathrm{H}-\mathrm{CC}$ & $121.70^{a}$ & & \\
\hline FAD. $T$. eminens & $14 \mathrm{H}-5,22$ & 128.72 & $14 \mathrm{H}-\mathrm{CC}$ & $121.70^{3}$ & & \\
\hline FAD C. asymmetricus & $14 \mathrm{H}-5,120$ & 129.70 & $15 \mathrm{H}-3,10$ & 127.60 & & \\
\hline FAD H. kleinpellii & $14 \mathrm{H}-5,120$ & 129.70 & - & - & CP5 & NP6 \\
\hline FAD C. consuetus & $14 \mathrm{H}-\mathrm{CC}$ & 130.60 & $15 \mathrm{H}-1,80$ & 127.60 & & \\
\hline FAD C. nitescens & $14 \mathrm{H}-\mathrm{CC}$ & 130.60 & $15 \mathrm{H}-2,80$ & 129.10 & & \\
\hline FAD S. anarrhopus & $15 \mathrm{X}-1,20$ & 132.20 & $15 \mathrm{H}-2,80$ & 129.10 & & \\
\hline FAD $F$. tympaniformis & $15 \mathrm{X}-1,20$ & 132.20 & $15 \mathrm{H}-3,10$ & 129.90 & CP4 & NP5 \\
\hline FAD F. pileatus & $15 \mathrm{X}-2,120$ & 134.70 & $15 \mathrm{H}-6,10$ & 134.40 & & \\
\hline
\end{tabular}

aClose to gap in recovery.

Note: Dash $(-)=$ indeterminable.

applied for D. sublodoensis (see Appendix for discussion). However, there appears to be an unconformity in the lower part of this zone. This has been determined from the coincidence of the FO of $D$. sublodoensis and the LO of Tribrachiatus orthostylus, events that define the upper and lower boundary of Zone NP13 of Martini (1971). Where Zone NP13 is complete, these events are separated by $4-15 \mathrm{~m}$ (Table 4). Interestingly, the unconformity corresponds to an interval impoverished in calcareous nannofossils and enriched in diagenetic bladed calcite, possibly as a result of seafloor dissolution. Another possible unconformity lies in Subzone CP12b (see below).

\section{$C P 12 b$ Rhabdosphaera inflata Subzone}

Definition: Total range of $R$. inflata or interval from the FO of $R$. inflata to the $\mathrm{FO}$ of $N$. fulgens

Age: middle Eocene

Hole 865B: $143-865 \mathrm{~B}-8 \mathrm{H}-\mathrm{CC}$ to $-8 \mathrm{H}-6,20 \mathrm{~cm}$

Hole 865C: $143-865 \mathrm{C}-9 \mathrm{H}-4,10 \mathrm{~cm}$, to $-9 \mathrm{H}-3,10 \mathrm{~cm}$

Comments: The range of $R$. inflata is 0.8 and $1.5 \mathrm{~m}$ in Holes $865 \mathrm{~B}$ and $865 \mathrm{C}$ respectively, considerably less than the $30-50 \mathrm{~m}$ recorded in other se- quences (Table 4). Either this species has a contracted range in the tropical Pacific or else this subzone is incomplete.

\section{CP12a Discoasteroides kuepperi Subzone}

Definition: Interval from the FO of $D$. sublodoensis to the FO of $R$. inflata Age: early Eocene

Hole 865B: $143-865 \mathrm{~B}-9 \mathrm{H}-4,10 \mathrm{~cm}$, to $-8 \mathrm{H}-\mathrm{CC}$

Hole 865C: $143-865 \mathrm{C}-10 \mathrm{H}-1,10 \mathrm{~cm}$, to $-9 \mathrm{H}-4,10 \mathrm{~cm}$

Comments: The base of this subzone appears to correlate to an unconformity (see discussion for Zone CP12).

\section{CP11 Discoaster lodoensis Zone}

Definition: Interval from the FO of Coccolithus crassus to the FO of D. sublodoensis

Age: early Eocene

Hole 865B: $143-865 \mathrm{~B}-9 \mathrm{H}-6,70 \mathrm{~cm}$, to $-9 \mathrm{H}-4,10 \mathrm{~cm}$ 


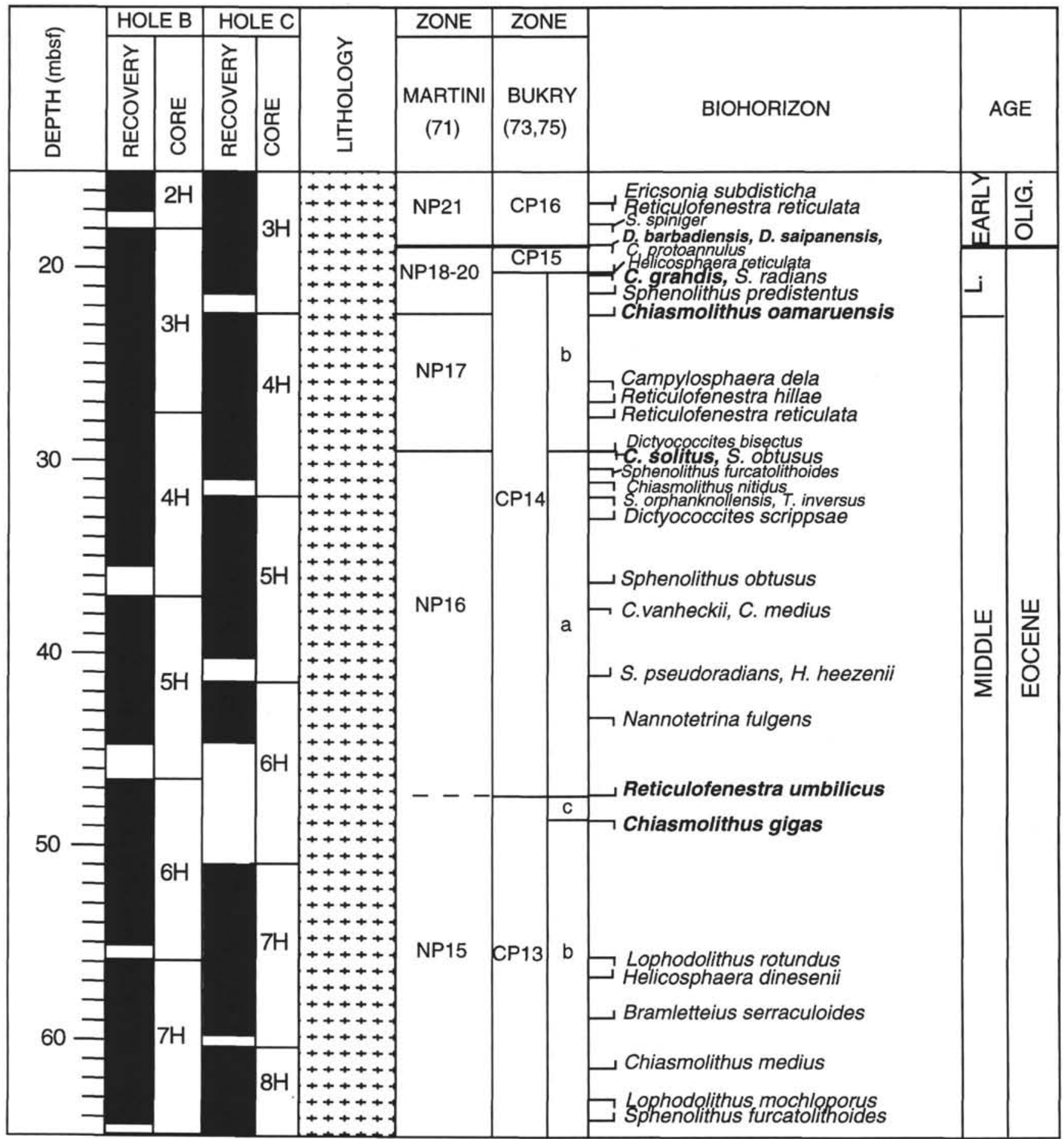

Figure 4. Calcareous nannofossil biostratigraphic summary of the middle Eocene to Oligocene interval of Holes $865 \mathrm{~B}$ and $865 \mathrm{C}$. Illustrated are the sub-bottom depth (meters below sea floor), recovery and core numbers in Holes 865B and 865C, lithology, interval of zonal units of Martini (1971) and Bukry (1973, 1975b), depths of zonal (bold) and nonzonal biohorizons, and age. The depths of biohorizons and zonal boundaries are averages determined from Holes 865B and 865C; excluded are events affected by core breaks in one hole. Where events are clustered in an interval, depths have been slightly adjusted for legibility. Dashed zonal boundaries indicate indirect correlation, boundaries shown in bold indicate unconformities.

Hole 865C: $143-865 \mathrm{C}-10 \mathrm{H}-3,10 \mathrm{~cm}$, to $-10 \mathrm{H}-1,10 \mathrm{~cm}$

Comments: $C$. crassus is fairly rare in both holes, especially when compared with other sites (e.g., Site 577; Monechi, 1985), and we have observed more gradation between this species and $C$. pelagicus than previously reported and described (see Appendix). There appears to be an unconformity in the top part of this zone (see discussion for Zone CP12).

\section{CP10 Tribrachiatus orthostylus Zone}

Definition: Interval from the $\mathrm{FO}$ of $D$. lodoensis to the $\mathrm{FO}$ of $C$. crassus Age: early Eocene

Hole 865B: $143-865 \mathrm{~B}-10 \mathrm{H}-4,60 \mathrm{~cm}$, to $-9 \mathrm{H}-6,70 \mathrm{~cm}$

Hole 865C: $143-865 \mathrm{C}-10 \mathrm{H}-\mathrm{CC}$ to $-10 \mathrm{H}-3,10 \mathrm{~cm}$ 


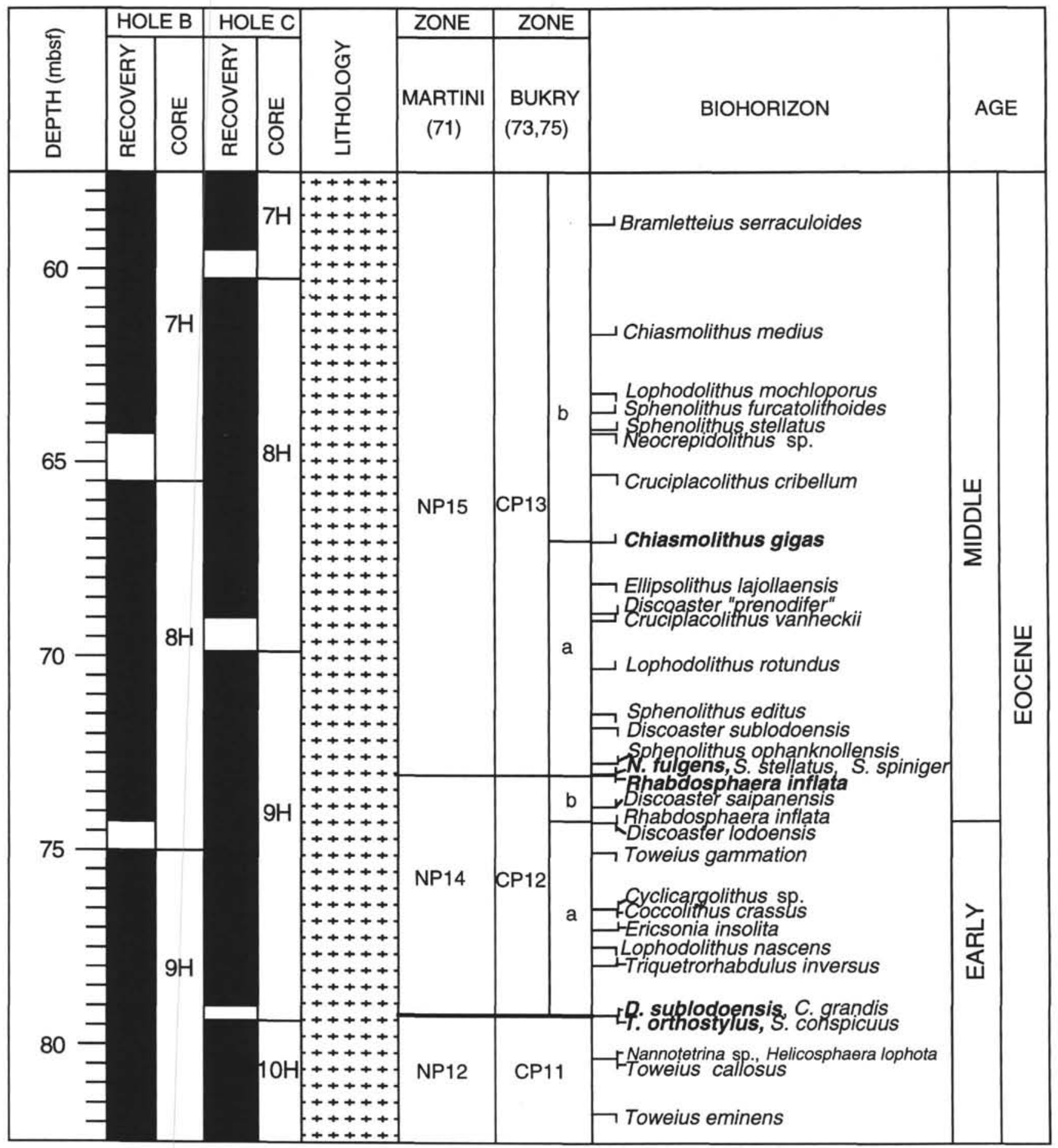

Figure 5. Calcareous nannofossil biostratigraphic summary of the early to middle Eocene interval of Holes 865B and 865C. The depths of biohorizons and zonal boundaries are averages determined from Holes $865 \mathrm{~B}$ and $865 \mathrm{C}$; excluded are events affected by core breaks in one hole. Zonal boundaries shown in bold indicate unconformities. See Figure 4 for explanation.

Comments: See comments for Zone CP11. We observed forms of $D$. lodoensis having rays numbering from five to eight. We included only forms having five to seven rays in this taxon (e.g., Aubry, 1984).

\section{CP9 Discoaster diastypus Zone}

Definition: Interval from the FOs of $D$. diastypus and/or $T$. bramlettei to the FO of $D$. lodoensis

Age: early Eocene
Hole 865B: $143-865 \mathrm{~B}-11 \mathrm{H}-6,70 \mathrm{~cm}$, to $-10 \mathrm{H}-4,60 \mathrm{~cm}$

Hole 865C: $143-865 \mathrm{C}-12 \mathrm{H}-3,138 \mathrm{~cm}$, to $-10 \mathrm{H}-\mathrm{CC}$

Comments: The base of this zone has sometimes been defined by the FO of $D$. diastypus. A few specimens resembling $D$. diastypus were observed in Hole $865 \mathrm{C}$ (Table 2); however, we classified these specimens as $D$. cf. $D$. diastypus, as a result of slight taxonomic differences (see Appendix). The base of this zone has typically been placed close to or at the Paleocene/ Eocene boundary (e.g., Bukry, 1973; Berggren et al., 1985). As originally defined, however, the base of Zone CP9 was placed at the FO of $T$. 


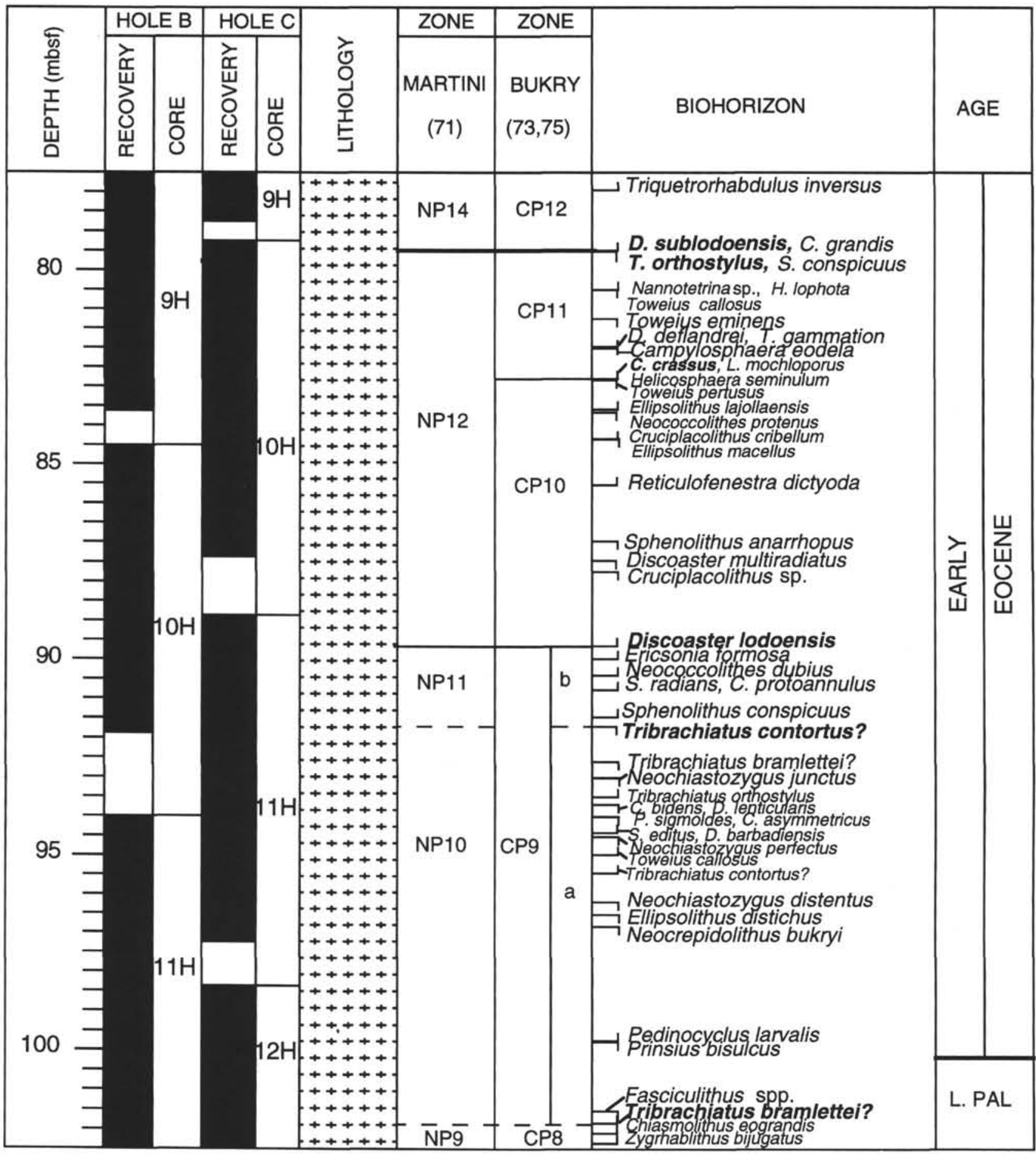

Figure 6. Calcareous nannofossil biostratigraphic summary of the latest Paleocene to early Eocene interval of Holes $865 \mathrm{~B}$ and $865 \mathrm{C}$. The depths of biohorizons and zonal boundaries are averages determined from Holes 865B and 865C; excluded are events affected by core breaks in one hole. Dashed zonal boundaries indicate uncertain identification of species of Tribrachiatus. Zonal boundaries shown in bold indicate unconformities. Position of Paleocene/Eocene boundary is based on planktonic foraminifer biostratigraphy (I. Premoli Silva and W. Sliter, pers. comm., 1993). See Figure 4 for explanation.

contortus, an event that lies clearly above the Paleocene/Eocene boundary in most sequences (e.g., Hay and Mohler, 1967; Pospichal and Wise, 1990). For this reason, the base of this zone has sometimes been redefined by the FO of T. bramlettei, the event that often has been used to define the Paleocene/Eocene boundary (e.g., Pospichal and Wise, 1990). We follow this latter definition here. Identification of $T$. bramlettei and $T$. contortus in overgrown material represents a significant problem, one that has been previously addressed by Hekel (1968). We discuss this issue in depth in the Appendix. In short, we observed forms that theoretically could be overgrown specimens of $T$. bramlettei and $T$. contortus, although the possibility exists that they are specimens of the ancestral taxon, Rhombaster cuspis. Our determination of the base of this zone and the Paleocene/ Eocene boundary (e.g., Figs. 6-7), therefore, must be viewed with considerable caution. In addition, as these taxa are rare, the precision with which their first (or last) occurrences can be detected may not be that high. See comments about $D$. lodoensis for Zone CP10. 


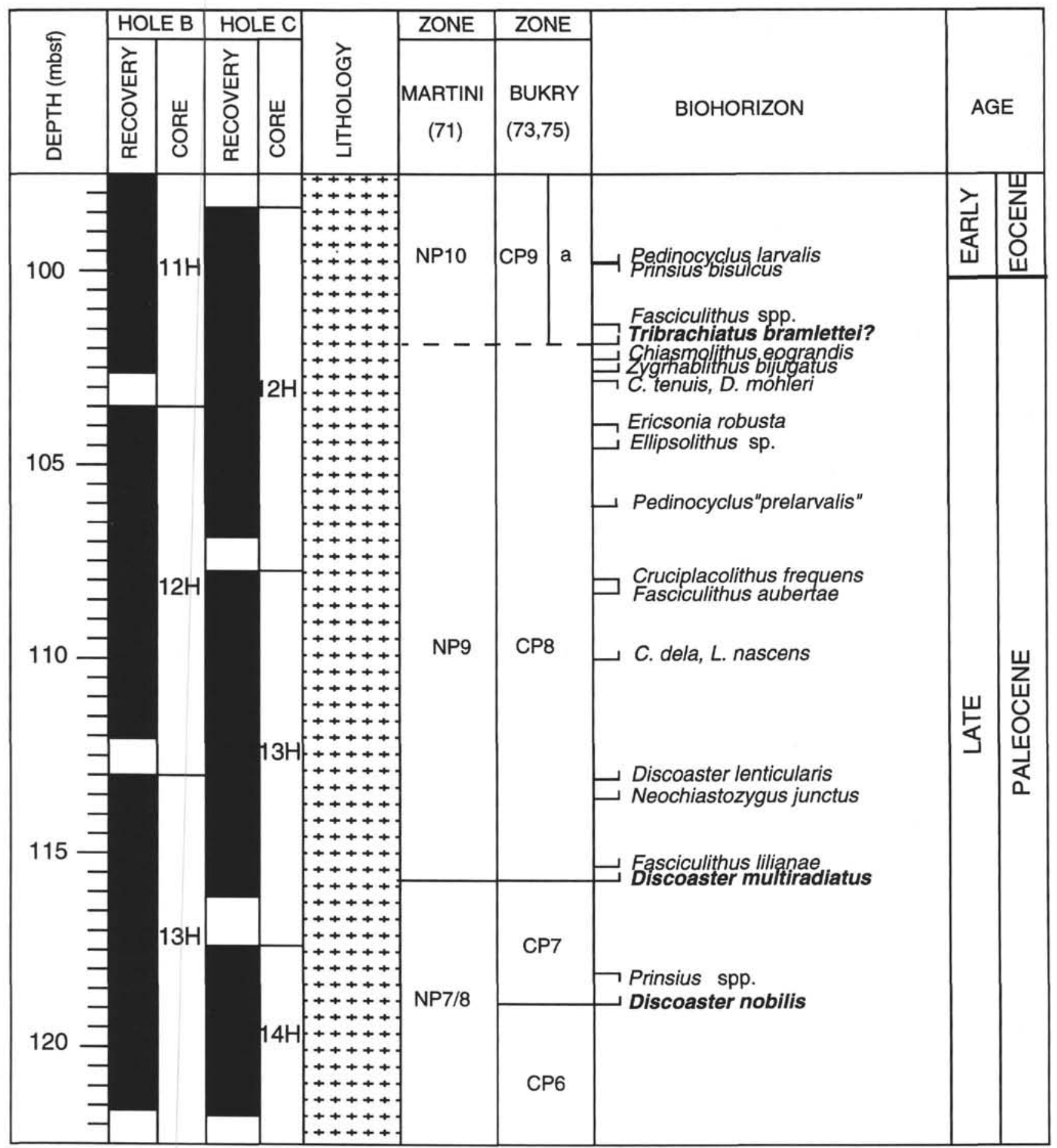

Figure 7. Calcareous nannofossil biostratigraphic summary of the late Paleocene to earliest Eocene interval of Holes 865B and 865C. The depths of biohorizons and zonal boundaries are averages determined from Holes 865B and 865C; excluded are events affected by core breaks in one hole. Dashed zonal boundaries indicate uncertain identification of species of Tribrachiatus. Position of Paleocene/Eocene boundary is based on planktonic foraminifer biostratigraphy (I. Premoli Silva and W. Sliter, pers. comm., 1993). See Figure 4 for explanation.

\section{CP9b Discoaster binodosus Subzone}

Definition: Interval from the LO of T. contortus to the FO of $D$. lodoensis Age: early Eocene

Hole 865B: $143-865 \mathrm{~B}-10 \mathrm{H}-5,111 \mathrm{~cm}$, to $-10 \mathrm{H}-4,60 \mathrm{~cm}$

Hole 865C: $143-865 \mathrm{C}-11 \mathrm{H}-2,134 \mathrm{~cm}$, to $-10 \mathrm{H}-\mathrm{CC}$

Comments: See comments for Zones CP9 and CP10.

\section{CP9a Tribrachiatus contortus Subzone}

Definition: Interval from the FOs of $D$. diastypus and/or $T$. bramlettei to the LO of $T$. contortus

Age: early Eocene

Hole 865B: $143-865 \mathrm{~B}-11 \mathrm{H}-6,70 \mathrm{~cm}$, to $-10 \mathrm{H}-5,111 \mathrm{~cm}$

Hole 865C: $143-865 \mathrm{C}-12 \mathrm{H}-3,138 \mathrm{~cm}$, to $-11 \mathrm{H}-2,134 \mathrm{~cm}$

Comments: See comments for Zone CP9. 


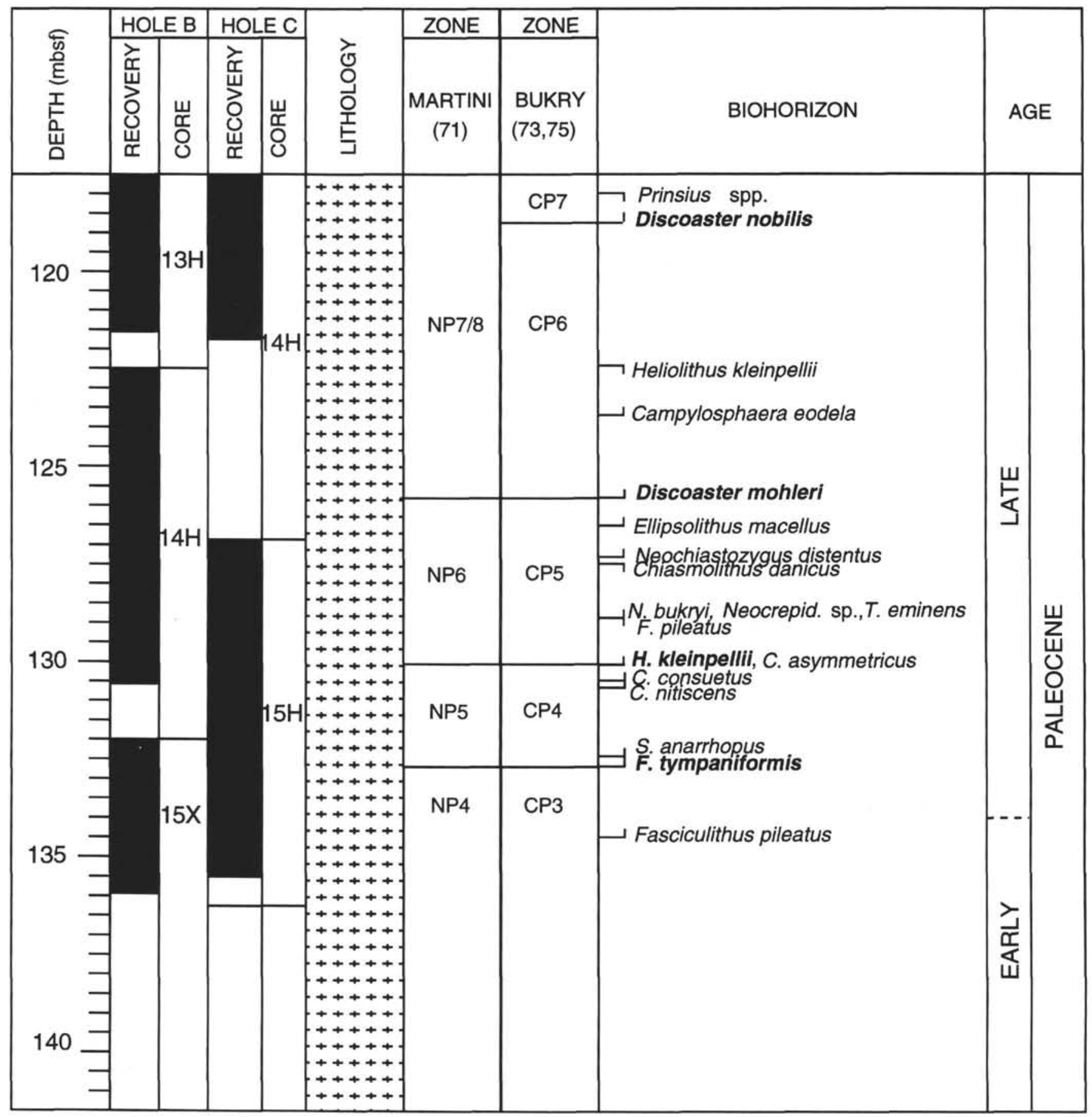

Figure 8. Calcareous nannofossil biostratigraphic summary of the early to late Paleocene interval of Holes $865 \mathrm{~B}$ and $865 \mathrm{C}$. The depths of biohorizons and zonal boundaries are averages determined from Holes $865 \mathrm{~B}$ and $865 \mathrm{C}$; excluded are events affected by core breaks in one hole. See Figure 4 for explanation.

\section{CP8 Discoaster multiradiatus Zone}

Definition: Interval from the FO of $D$. multiradiatus to the FOs of $D$. diastypus and/or $T$. bramlettei

Age: late Paleocene

Hole 865B: $143-865 \mathrm{~B}-13 \mathrm{H}-3,21 \mathrm{~cm}$, to $-11 \mathrm{H}-6,70 \mathrm{~cm}$

Hole 865C: $143-865 \mathrm{C}-13 \mathrm{H}-5,80 \mathrm{~cm}$, to $-12 \mathrm{H}-3,138 \mathrm{~cm}$

Comments: See comments on definition of Zone CP9. The base of this zone can be accurately determined. As discussed above, the FO of $T$. bramlettei as determined here (e.g., Figs. 6-7) should be viewed with caution as a result of the uncertain identification of this species (see Appendix).

\section{CP8b Campylosphaera eodela Subzone}

Definition: Interval from the FOs of $C$. eodela and/or Rhombaster spp, to the FOs of $D$. diastypus and/or $T$. bramlettei

Age: late Paleocene

Hole 865B: Not applicable

Hole 865C: Not applicable

Comments: The FO of $C$. eodela is not only lower relative to other nannofossil events than has been determined previously (identification of this species is discussed in the Appendix), but it also lies below the FO of $D$. multiradiatus, which defines the base of Zone CP8. Therefore, this interval cannot 
Table 4. Meter levels of major biohorizons in other DSDP/ODP holes.

\begin{tabular}{|c|c|c|c|c|c|c|c|c|c|c|c|c|c|c|c|c|}
\hline \multirow[b]{2}{*}{ Biohorizon } & \multicolumn{2}{|c|}{ Pacific } & \multicolumn{5}{|c|}{ South Atlantic } & \multicolumn{5}{|c|}{ North Atlantic } & \multicolumn{2}{|c|}{ Indian } & \multicolumn{2}{|c|}{ Land } \\
\hline & $865 \mathrm{~B}$ & 577 & $516 \mathrm{~F}$ & $523 / 524$ & $690 \mathrm{~B}$ & $386 / 384$ & 405 & 549 & $553 \mathrm{~A}$ & 605 & 647 & 738 & 748 & $762 \mathrm{C}$ & Contessa & Califomia \\
\hline FAD E. subdisticha & 17.90 & & & & & 284.30 & & 203.19 & & & & & & 183.50 & & \\
\hline LAD D. barbadiensis & 18.70 & & 533.19 & 98.87 & & 286.30 & & & & & 288.88 & & & & & \\
\hline LAD $C$. grandis & 19.32 & & 617.45 & & 108.10 & 329.42 & & & & & 434.81 & & & 247.05 & 138.5 & \\
\hline FAD $H$. reticulata & 19.32 & & & & & 282.90 & & & & & & & & 259.49 & & \\
\hline FAD S, predistentus & 20.46 & & 533.19 & & & 284.30 & & & & & 451.32 & & & 190.00 & & \\
\hline FAD C. oamaruensis & 22.40 & & & 113.17 & & 289.40 & & 203.19 & & & 437.13 & & 36.50 & & & \\
\hline LAD $C$. dela & 26.19 & & & 139.54 & & 348.39 & & 206.00 & & & 440.81 & & & 257.99 & & \\
\hline FAD $R$. reticulata & 27.66 & & 733.29 & & 105.10 & & & 209.20 & & & $518.74^{\mathrm{a}}$ & & 82.50 & 273.50 & & \\
\hline FAD D. bisectus & 29.40 & & 673.05 & 120.50 & & 310.65 & & & & & 455.61 & & 33.00 & & 138.5 & \\
\hline LAD C. solitus & 29.40 & & 645.15 & 136.09 & & 329.42 & & & & & 454.12 & & 43.80 & 277.30 & & \\
\hline LAD $S$. furcatolithoides & 29.40 & & 692.12 & 136.09 & & 329.42 & & 206.00 & & 222.5 & 457.08 & & & 264.50 & & \\
\hline LAD $T$, inversus & 31.41 & & & 136.09 & & & & & & & & & & 285.00 & & \\
\hline FAD D. scrippsae & 33.07 & & & 134.11 & & 337.00 & & & & & & & & 262.49 & & \\
\hline FAD $S$. pseudoradians & 40.70 & & & $103.20^{\mathrm{a}}$ & & & & & & & & & & 199.34 & & \\
\hline LAD N. fulgens & 44.54 & & 766.88 & 154.74 & & 337.00 & & & & & 540.00 & & & & & \\
\hline FAD R. umbilicus & 47.31 & & 786.29 & 146.20 & 108.10 & 337.00 & & 275.16 & & 250.8 & & & 84.00 & 306.99 & 110.2 & \\
\hline LAD C. gigas & 48.73 & & & & & 348.39 & & 251.09 & & & & & & 292.50 & & \\
\hline FAD B. serraculoides & 59.69 & & 663.95 & $120.25^{\mathrm{a}}$ & & 329.42 & & & & & & & & 294.50 & & \\
\hline FAD S. furcatolithoides & 64.04 & & 786.29 & 183.30 & & 375.00 & & 256.22 & & 309.9 & 600.43 & & & 297.70 & & \\
\hline FAD C. gigas & 67.70 & & 824.10 & 167.40 & & 409.65 & & 268.16 & & 318.0 & & & & 297.70 & & \\
\hline LAD D. sublodoensis & 72.20 & & 854.63 & & 115.81 & 451.10 & & 270.00 & & 346.8 & & & 101.50 & 313.49 & & \\
\hline LAD $R$. inflata & 73.20 & & & & & 451.10 & 74.75 & 270.00 & & 351.0 & & & & & & \\
\hline FAD N. fulgens & 73.20 & & 848.81 & & & 475.00 & & & & 346.8 & & & & & 90.0 & \\
\hline FAD D. saipanensis & 74.00 & 67.00 & 786.29 & & & 475.00 & & $206.00^{\mathrm{a}}$ & & 425.1 & & & & 308.30 & 125.0 & 374.0 \\
\hline FAD $R$. inflata & 74.00 & & & & & 501.70 & 93.50 & 275.16 & & 386.7 & & & & & & 359.0 \\
\hline LAD D. lodoensis & 74.00 & 68.00 & 854.63 & & 127.78 & 451.00 & 71.30 & 277.60 & & 370.0 & & & 123.80 & 313.49 & & \\
\hline LAD $T$. gammation & 75.13 & 71.00 & & & & $348.39^{\mathrm{a}}$ & & & & 386.7 & & & & 319.49 & & \\
\hline LAD C. crassus & 76.13 & 68.50 & & & & 508.40 & & & & & & & & & 70.0 & \\
\hline FAD Cyclicargolithus sp. & 76.13 & & & & & 541.66 & & & 246.63 & & & & & 332.50 & 70.0 & \\
\hline FAD $T$. inversus & 77.50 & 72.00 & & & & & & 284.99 & & & & & & 330.50 & 53.0 & \\
\hline LAD L. nascens & 77.50 & & 897.02 & & & 577.76 & 138.70 & $\begin{array}{l}284.99 \\
304.77\end{array}$ & 253.12 & & & & & & & \\
\hline FAD C. grandis & 79.60 & 73.26 & $\begin{array}{l}897.02 \\
887.83\end{array}$ & & 131.41 & 513.67 & 94.19 & 277.60 & 245.48 & $\begin{array}{l}510.4 \\
437.7\end{array}$ & & & & 369.00 & 51.5 & $\begin{array}{l}358.0 \\
310.0\end{array}$ \\
\hline FAD D. sublodoensis & 79.60 & & $\begin{array}{l}887.83 \\
878.17\end{array}$ & & 129.91 & 527.40 & & 284.99 & 248.30 & $\begin{array}{l}437.7 \\
452.4\end{array}$ & & & 119.80 & 329.00 & 70.0 & 310.0 \\
\hline LAD $T$. orthostylus & 79.60 & 72.00 & & & & 527.40 & 93.50 & & & $\begin{array}{l}452.4 \\
538.8\end{array}$ & & & 188.20 & 335.50 & 60.0 & \\
\hline $\begin{array}{l}\text { FAD H. lophota } \\
\text { LAD T. callosus }\end{array}$ & $\begin{array}{l}80.50 \\
80.50\end{array}$ & & 875.21 & & 110.31 & & & 284.00 & & & & 226.26 & $84.00^{\mathrm{a}}$ & & & \\
\hline FAD $T$. gammation & 81.70 & 76.50 & 070.21 & & 100.01 & 556.69 & & 207,00 & & 529.2 & & 220.20 & & & 44.0 & \\
\hline FAD $H$. seminulum & 83.20 & & & & & 527.40 & 334.37 & & & 530.9 & & & & & & \\
\hline LAD T, eminens & 83.20 & & & & & 584.20 & 380.48 & 335.55 & & & & & & & 51.5 & \\
\hline FAD E. lajollaensis & $\begin{array}{l}83.60 \\
84.73\end{array}$ & & & & 131.41 & $\begin{array}{l}520.76 \\
577.76\end{array}$ & & & & & & & & 389.50 & 48.0 & \\
\hline $\begin{array}{l}\text { FAD C. cribellum } \\
\text { FAD E. macellus }\end{array}$ & $\begin{array}{l}84.73 \\
84.73\end{array}$ & 74.00 & 889.90 & & & $\begin{array}{l}577.76 \\
541.66\end{array}$ & & 303.49 & 259.93 & 510.4 & & & & & & \\
\hline FAD $R$. dictyoda & 87.22 & 67.00 & & & 137.41 & 537.86 & & & 248.30 & 442.8 & & & 178.00 & 392.50 & & \\
\hline LAD D. multiradiatus & 88.10 & 73.50 & 901.56 & & 137.41 & 577.20 & & 331.50 & & 500.4 & & 274.46 & & 381.20 & $70.0^{\mathrm{a}}$ & \\
\hline FAD D. lodoensis & 89.60 & 74.60 & 898.23 & & 134.41 & 565.20 & 403.80 & 299.50 & 254.50 & 538.8 & & 264.10 & & 369.00 & 48.0 & \\
\hline FAD $E$. formosa & 89.60 & 72.91 & 897.03 & & 137.80 & $617.70^{\mathrm{a}}$ & 399.37 & 296.95 & & 510.4 & & 273.80 & & & 48.0 & \\
\hline FAD N. dubius & 90.20 & & 898.23 & & $174.59^{\mathrm{a}}$ & 579.02 & & 335.00 & & 510.4 & & $293.00^{2}$ & & 331.40 & & 362.0 \\
\hline FAD $S$, radians & 90.54 & 79.50 & & & & $409.65^{a}$ & & & & 551.4 & & & & 392.50 & 31.0 & \\
\hline LAD T. conortus (?) & 91.64 & 79.50 & & & & & & & & & & & & & & \\
\hline FAD T. orthostylus & 93.50 & 80.00 & 898.23 & & 137.80 & 578.66 & & 330.89 & 259.93 & 551.4 & & & & & 39.0 & \\
\hline $\begin{array}{l}\text { FAD } S \text {. editus } \\
\text { LAD } P \text { sigmoides }\end{array}$ & 94.20 & & & & 137.41 & & & & & 552.9 & & & & & & \\
\hline $\begin{array}{l}\text { LAD } P \text {. sigmoides } \\
\text { FAD D barbadiensis (?) }\end{array}$ & $\begin{array}{l}94.70 \\
95.29\end{array}$ & 81.00 & 901.56 & & & 584.20 & & 353.88 & & & & & & 406.49 & 31.0 & 358.0 \\
\hline $\begin{array}{l}\text { FAD D. barbadiensis (?) } \\
\text { FAD } T \text {. callosus }\end{array}$ & $\begin{array}{l}95.29 \\
95.29\end{array}$ & 80.75 & $\begin{array}{l}898.23 \\
910.34\end{array}$ & & $186.99^{a}$ & 579.02 & & $\begin{array}{l}304.77^{\mathrm{a}} \\
335.00\end{array}$ & 254.25 & 558.0 & & $\begin{array}{l}275.96 \\
293.00\end{array}$ & & 335.50 & 39.0 & \\
\hline $\begin{array}{l}\text { FAD T. callosus } \\
\text { FAD T. bramlettei }\end{array}$ & 102.20 & & 910.34 & & 149.29 & 606.37 & & 335.00 & & 558.0 & & & & & & \\
\hline LAD Fasciculithus spp. & 102.20 & 82.10 & 901.56 & 48.50 & 147.79 & 579.02 & & & & 550.5 & & 283.40 & & 394.00 & 38.0 & 1045.0 \\
\hline FAD Z. bijugatus & 102.50 & 82.28 & 901.56 & 33.50 & $191.49^{\mathrm{a}}$ & 577.76 & & & & 558.0 & & 293.00 & & 422.50 & 38.0 & \\
\hline LAD C. tenuis & 103.54 & 90.00 & 906.91 & 88.00 & & & & & & & & & & 414.00 & $21.0^{\mathrm{a}}$ & \\
\hline LAD D. mohleri & 103.54 & 83.00 & 908.61 & 48.50 & $137.80^{\mathrm{a}}$ & 607.98 & & & & & & & & & 39.0 & 647.0 \\
\hline $\begin{array}{l}\text { LAD E. robusta } \\
\text { FAD L. nascens }\end{array}$ & $\begin{array}{l}105.20 \\
111.20\end{array}$ & & & 57.65 & & 584.20 & & & & & & & & & & \\
\hline FAD D. multiradiatus & 116.21 & 86.00 & 913.62 & 63.65 & 185.49 & 612.70 & & & & & & & & 414.00 & 30.0 & 725.0 \\
\hline FAD D. nobilis & 120.00 & 88.50 & & & & 116.60 & & & & & & & & & & 483.0 \\
\hline LAD H. kleinpellii & 122.70 & 92.10 & 804.51 & 71.00 & 205.99 & 117.30 & & & & & & & & 436.60 & 23.5 & 491.0 \\
\hline FAD D. mohleri & 125.75 & 95.64 & 921.45 & 71.00 & 204.49 & 122.30 & & & & & & & & 436.60 & 23.5 & 455.0 \\
\hline FAD $N$. distentus & 127.23 & & & & & & & & & & & & & & & 483.0 \\
\hline LAD F. pileatus & 128.72 & 96.00 & & & & 132.53 & & & & & & & & & 21.0 & \\
\hline FAD $T$. eminens & 128.72 & 100.20 & & 93.70 & 217.16 & 132.53 & & & & & & & & 462.09 & & \\
\hline FAD $H$. kleinpellii & 129.70 & 95.64 & 929.62 & 78.70 & 213.40 & 126.60 & & & & & & & & 453.80 & 21.0 & 400.0 \\
\hline FAD F. tympaniformis & 132.20 & 98.00 & 940.10 & 109.83 & 229.40 & 141.56 & & & & & & & & 479.49 & 16.0 & \\
\hline FAD F. pileatus & 134.70 & 101.50 & & & & 150.70 & & & & & & & & 481.70 & 15.0 & \\
\hline
\end{tabular}

a Omitted from Figure 12.

Note: $\mathrm{FAD}=$ first appearance datum, and $\mathrm{LAD}=$ last appearance datum.

be defined at Site 865 . Rhombaster spp. has not been positively identified at Site 865 .

\section{CP8a Chiasmolithus bidens Subzone}

Definition: Interval from the FO of D. multiradiatus to the FOs of $C$. eodela and/or Rhombaster spp.

Age: late Paleocene

Comments: See comments for above subzone.

\section{CP7 Discoaster nobilis Zone}

Definition: Interval from the FO of $D$. nobilis to the FO of $D$. multiradiatus Age: late Paleocene

Hole 865B: $143-865 \mathrm{~B}-13 \mathrm{H}-5,100 \mathrm{~cm}$, to $-13 \mathrm{H}-3,21 \mathrm{~cm}$

Hole 865C: $143-865 \mathrm{C}-14 \mathrm{H}-1,10 \mathrm{~cm}$, to $-13 \mathrm{H}-5,80 \mathrm{~cm}$

Comments: Discoaster nobilis can be difficult to identify when assemblages are both overgrown and etched, as they are at the base of this zone at Site 865. See Appendix for full discussion. This is a relatively thin zone. 


\section{CP6 Discoaster mohleri Zone}

Definition: Interval from the FO of D. mohleri to the FO of D. nobilis Age: late Paleocene

Hole 865B: $143-865 \mathrm{~B}-14 \mathrm{H}-3,25 \mathrm{~cm}$, to $-13 \mathrm{H}-5,100 \mathrm{~cm}$

Hole 865C: $143-865 \mathrm{C}-14 \mathrm{H}-\mathrm{CC}$ to $-14 \mathrm{H}-1,10 \mathrm{~cm}$

Comments: At the base of this zone, specimens of $D$. mohleri are different from the typical morphology of this species. See Appendix for discussion.

\section{CP5 Heliolithus kleinpellii Zone}

Definition: Interval from the FO of $H$. kleinpellii to the FO of $D$. mohleri Age: late Paleocene

Hole 865B: $143-865 \mathrm{~B}-14 \mathrm{H}-5,120 \mathrm{~cm}$, to $-14 \mathrm{H}-3,25 \mathrm{~cm}$

Hole 865C: In coring gap

Comments: This zone can be precisely determined in Hole $865 \mathrm{~B}$, but it lies largely within a coring gap in Hole $865 \mathrm{C}$. This correlation does not show in Figure 8 because depths of the relevant biohorizons appear to be different in Holes $865 \mathrm{~B}$ and $865 \mathrm{C}$

\section{CP4 Fasciculithus tympaniformis Zone}

Definition: Interval from the FO of $F$. tympaniformis to the FO of $H$. kleinpellii Age: late Paleocene

Hole 865B: $143-865 \mathrm{~B}-15 \mathrm{X}-1,20 \mathrm{~cm}$, to $-14 \mathrm{H}-5,120 \mathrm{~cm}$

Hole 865C: $143-865 \mathrm{C}-15 \mathrm{H}-3,10 \mathrm{~cm}$, to $-14 \mathrm{H}-\mathrm{CC}$

Comments: This zone can be precisely determined in Hole $865 \mathrm{~B}$, but the upper part lies within the coring gap in Hole $865 \mathrm{C}$. See comments for Zone CP5.

\section{CP3 Ellipsolithus macellus Zone}

Definition: Interval from the $\mathrm{FO}$ of $E$. macellus to the $\mathrm{FO}$ of $F$.tympaniformis Age: early-late Paleocene

Hole 865B: Base of Cenozoic section to 143-865B-15X-1, $20 \mathrm{~cm}$

Hole 865C: Base of section to 143-865C-15H-3, $10 \mathrm{~cm}$

Comments: The base of this zone cannot be defined because the FO of the nominate taxon lies much higher in the section in both holes (Table 3 ). The FO of E. macellus is a highly diachronous event. This issue was discussed in detail by Backman (1986), who found that this event at Site 577 lay in an unconformity separating at least part of Zones NP6 and NP7. Our results (Table 3 and Fig. 8) concur with this. The FO of E. macellus lies in the middle of the range of Heliolithus kleinpellii in Hole 865B, below the FO of Discoaster mohleri (i.e., within Zone NP6). In Hole 865C, this event lies within a coring gap; the relative timing of this event, therefore, cannot be determined accurately. Nonetheless, as suggested by Backman (1986), the base of Zone NP4 (CP3) should be defined by alternative markers in the tropical Pacific, probably the FO of Sphenolithus, which lies close to this event in other sites (e.g., DSDP Site 577). Thus, we assume that the lowermost interval lies in Zone CP3, because of the presence of Sphenolithus moriformis throughout the lowermost interval of both holes.

\section{Application of the Martini (1971) Zonation}

Several of Martini's (1971; M71) zones have similar definitions for their upper or lower boundaries (Figs. 4-8 and Table 3); hence, the observations and comments listed above pertain to these zones too. This is particularly true for Paleocene and early Eocene zones. The M71 zones, which cannot be defined at Site 865 , are discussed in the following.

The base of the Heliolithus riedelii Zone (NP8) cannot be defined, as only one or two specimens of the nominate taxon were observed in sediments at Site 865 . We have identified a more common form of Heliolithus, which we have classified as $H$. cantabriae (see Appendix).

We used the FO of Nannotetrina fulgens to define the base of the Chiphragmalithus alatus Zone, which was defined in M71 by the FO of the nominate taxon ( $N$. alata). A complete discussion of this topic is given above under the Nannotetrina quadrata Zone (CP13), the base of which has a similar definition.

The base of the Discoaster tanii nodifer Zone (NP16) is defined by the FO of Rhabdosphaera gladius, a species that was not observed in sediments from Site 865.

Several zones of M71 differ from those of OB80 in one or more of their boundary definitions. The Discoaster lodoensis Zone (NP13), the top and base of which are defined by the FO of $D$. sublodoensis and the LO of $T$. orthostylus, respectively, appears to be missing as these events coincide in both holes (Table 3 and Fig. 5).

Chiasmolithus oamaruensis, the FO of which defines the base of its nominate zone (NP18), has a short range in Holes $865 \mathrm{~B}$ and $865 \mathrm{C}$; hence, the determination of the base of this zone is probably fairly precise. The base of the Isthmolithus recurvus Zone (NP19), defined by the FO of the nominate species, which does not occur in tropical locations, cannot be defined. Finally, the base of the Sphenolithus pseudoradians Zone (NP20), also defined by the FO of the nominate taxon, is problematic as this level lies considerably lower than that proposed by M71 (e.g., Perch-Nielsen, 1985).

Therefore, in conclusion, one of the M71 zones (NP20) and one of the OB80 subzones (CP8b) cannot be applied, as the basal markers appear well within underlying zones at Site 865. Future application of these zones needs to be tested in other sequences.

\section{DISCUSSION Application of Secondary Calcareous Nannofossil Biohorizons}

Routinely applied Paleogene calcareous nannofossil zonations, M71 and OB80, have been in existence for a number of years. Both of these schemes were derived on the basis of biostratigraphic data from sites distributed over a wide geographic range. Thus, both schemes have proven to be widely applicable in subdividing sequences of this age. OB80 was derived largely on the results of low-latitude areas (Bukry, 1973, 1975a, 1975b; Okada and Bukry, 1980), whereas M71 had more of a latitudinal range, including sites in temperate regions. Recently, however, recovery of Paleogene sequences in high latitudes, from where no information was available at the time the original zonations were derived, showed that they could not be applied in particular time intervals (e.g., Wise and Wind, 1977; Pospichal and Wise, 1990; Aubry, 1992b). For this reason, new zonal units were proposed (e.g., Wise, 1983; Wei and Pospichal, 1991). As discussed above, Site 865 is the first known low-latitude section in which several of the OB80 and M71 zonal units could not be applied. For example, as a result of the sparsity or absence of certain species of Discoaster and Rhabdosphaera (e.g., D. diastypus and $R$. gladius), particular lower and middle Eocene zones in both schemes could not be reliably delineated. Reasons for the absence of certain markers are discussed in the following section. We postulate that definition of new zonal units to fit the biostratigraphy of Site 865 is not a good solution for this problem for several reasons. For one, this is a single site, and realistically several sites are required before new zonation schemes can be defined. Furthermore, even if several sites were available to define a new scheme, this would lead to a large amount of confusion in the literature, as the two standard Paleogene schemes have been successfully applied in a range of sites for a number of years.

An alternative to defining new zonal units is to subdivide previous zonal units into formally or informally defined subzones. This rationale has been used in the Cretaceous (e.g., Bralower et al., 1993). Several of the zonal units in the OB 80 scheme have already been divided into such units. Division of zonal units into subzones is a preferable alternative to defining new zones, as it is possible to maintain internal consistency among widely used zonal units. However, once again, we do not think that such formal stratigraphic units should be defined based on the results of one site. It is far more important at this time to evaluate the biostratigraphic merits of particular biohorizons, to deduce the relative order of all events, and to attempt to determine whether they are closely synchronous or diachronous among sites distributed over a range of latitudes and representing a variety of oceanographic settings. One of the major reasons for attempting such an ordering of available biohorizons is to increase biostratigraphic resolution. This is particularly important, in sections such as those recovered at Site 865 , in which a detailed magnetostratigraphy is unavailable. Current resolution using Paleogene nannofossil biostratigraphy 
is fairly poor: 1 to 3 m.y. per zone (Moore and Romine, 1981). Yet, there are intervals in which rates of evolution and extinction are high (e.g., Haq, 1973) and a large number of events are available for consideration (Table 3). Figure 9 shows a plot of the sub-bottom depth of 134 events determined precisely in both Holes 865B and 865C (i.e., excluding other events that have been affected by gaps in coring in one or both holes). This plot illustrates the consistency between the order of all but three events: the LOs of Ellipsolithus distichus, Neochiastozygus perfectus, and Neocrepidolithus sp. The Spearman correlation coefficient between these datums in the two holes is 0.999 . The results of our study of Site 865 , therefore, provide a basis with which to compare the order of zonal and nonzonal Paleogene biohorizons.

A previous attempt to order numerous secondary marker taxa was made by Hay and Steinmetz (1973) on the basis of the biostratigraphies of 13 upper Paleocene-lower Eocene sequences in California. Highly variable sequences of events were found; however, 11 FOs and 9 LOs were ordered reasonably consistently. Application of this scheme is diminished by significant changes in taxonomic concepts in the last two decades.

The approach of Hay and Steinmetz (1973) was applied to the biostratigraphic results of a single region. In this section, we go one step farther, comparing the order of events at Site 865 with those from other deep-sea sections from a variety of different latitudes. The variability between the order of events will likely increase as sections from a host of regions are considered and as more events are included. To reduce the amount of the latter type of variability, we have analyzed factors that might affect this variability in all available events in our sections, including the following: abundance in Paleogene material in broad terms, taxonomic distinctiveness (i.e., how significantly does that form differ from others), taxonomic uniformity between different workers (i.e., the variability of species concepts between different workers in the field), resistance to dissolution, paleobiogeographic distribution, and known diachroneity between sequences. These factors are compiled for all of the potential biohorizons in Table 5. Based on these factors, we have selected 72 zonal and nonzonal events that we feel offer the most potential for correlation of distant sites.

The most precise method of determining the synchroneity or diachroneity of biostratigraphic events over broad areas is to use the sequence of magnetostratigraphic polarity zones within sedimentary sequences. This technique is dependent on the ability to identify clearly and correlate the sequence of polarity zones regardless of their biostratigraphic correlations; if biostratigraphic events are required to identify polarity zones in particular sections, this technique can be invalidated by "circular reasoning." The synchroneity/diachroneity of a number of Paleogene nannofossil events has been addressed in this fashion by Wei and Wise (1989) and Wei (1992), and we refer to the results of these studies in the following.

Where magnetostratigraphy is unavailable, as at Site 865 , other approaches have to be used to assess the synchroneity/diachroneity of fossil datums. One such approach is an application of the technique of Shaw (1964), in which $x$ - $y$ plots of various types of events in two different sequences are used to analyze the sedimentation histories of these two sections. This technique has been widely applied in biostratigraphy. The disadvantage of this technique is that it only indirectly implies synchroneity/diachroneity, whereas magnetostratigraphy provides a more direct line of evidence. An advantage is that this technique also provides evidence about the relative completeness of sedimentary sequences, as it was established to do (Shaw, 1964). Therefore, in the following, we discuss not only the relative order of nannofossil events in different sequences, but also the implication of the spacing of events on the relative completeness of different sections, especially at Site 865 .

A comparison of the meter levels of 72 events with those in 16 other sequences is shown in Table 4. For this analysis, we have chosen other deep-sea and continental-margin sites in which a detailed calcareous nannofossil biostratigraphy has been conducted and for which range charts including relative abundance data have been compiled. Only one other site in the Pacific was included: DSDP Site 577 on the

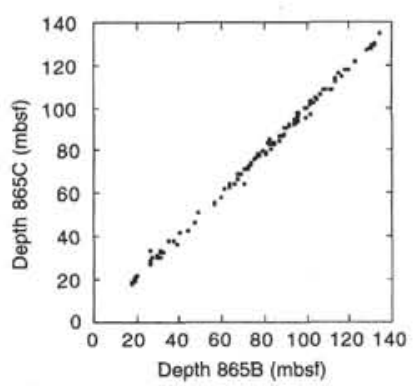

Figure 9. Meter level of more reliable Paleogene nannofossil biohorizons in Hole $865 \mathrm{~B}$ vs. Hole $865 \mathrm{C}$. See text for more detailed discussion.

Shatsky Rise (Monechi, 1985; Backman, 1987). Four sites in the South Atlantic were considered: DSDP Sites 516 on the Rio Grande Rise (Wei and Wise, 1989), 523 on the mid-Atlantic Ridge, and 524 on the Walvis Ridge (Percival, 1983); and ODP Site 690 on the Maud Rise in the Weddell Sea (Pospichal and Wise, 1990; Wei and Wise, 1990). Seven North Atlantic sites were included: DSDP Sites 384 (J-Anomaly Ridge) and 386 (Bermuda Rise) (Okada and Thierstein, 1979); DSDP Sites 405 and 553 on the Rockall Plateau (Müller, 1979; Backman, 1984), DSDP Site 549 on the Goban Spur (Müller, 1985), DSDP Site 605 on the continental margin of the United States off the coast of New Jersey (Applegate and Wise, 1987), and ODP Site 647 in the Labrador Sea (Firth, 1989). Data from three Indian Ocean sites were compiled: ODP Sites 738 and 748 on the Kerguelen Plateau (Wei and Thierstein, 1991; Aubry, 1992b), and ODP Site 762 on the Exmouth Plateau (Siesser and Bralower, 1992). We have also included two "classic" land sections: the Contessa section in the Umbrian Apennines of Italy (Monechi and Thierstein, 1985), and a composite section from the California Coast Ranges (Filewicz and Hill, 1983). These latter sections were the subject of the pioneering study of Bramlette and Sullivan (1961); however, using the original references proved to be difficult because of differences in the taxonomic concepts applied in 1961 with those currently used. In all of the sections analyzed, we have excluded events that are (1) based on two or fewer occurrences and (2) clearly out of sequence as a result of taxonomic differences among authors. The sub-bottom depths of the remaining events in the other sites are compared with those in Hole 865B in $x-y$ plots (Fig. 10).

Differences in order among sections may result from a number of factors. These include inaccuracy when determining an event, differences in taxonomic concepts among various workers, and diachroneity of an event in different parts of the ocean. For most sections, including Sites $384,386,516,523,524,549,553,577,605,647,690$, 762 , and the Contessa section, we observed that numerous similarities exist; however, we noted several striking differences in the order of the selected events at Site 865 . Other sections, including Sites 405 , 738,748 , and the California sections, have a larger proportion of dissimilarities in order. We do not think that an intrinsic difference exists between the two groups of sections; rather, we feel that the latter group represents shorter intervals of the Paleogene in which variability in order is no greater than in intervals within the longer sections. In several cases in both groups, the variability is so great that it is not possible to determine those datums that are consistent with the proposed order at Site 865 and those datums that are not. In other cases, however, the anomalous datums are clearer. In the following, we consider the most likely reasons for these anomalies. The position relative to the proposed correlation line, whether too low (i.e., too old) at the other site or too high (i.e., too young), is indicated.

In seven sections, the most consistent order of events is straightforward. At DSDP Site 577, the relative order of 25 out of 32 (78\%) events is similar to Site 865 (Fig. 10A). Major departures in order include the FOs of Toweius eminens (too low at Site 577), Chiasmolithus grandis (low), and Reticulofenestra dictyoda (too high at Site 

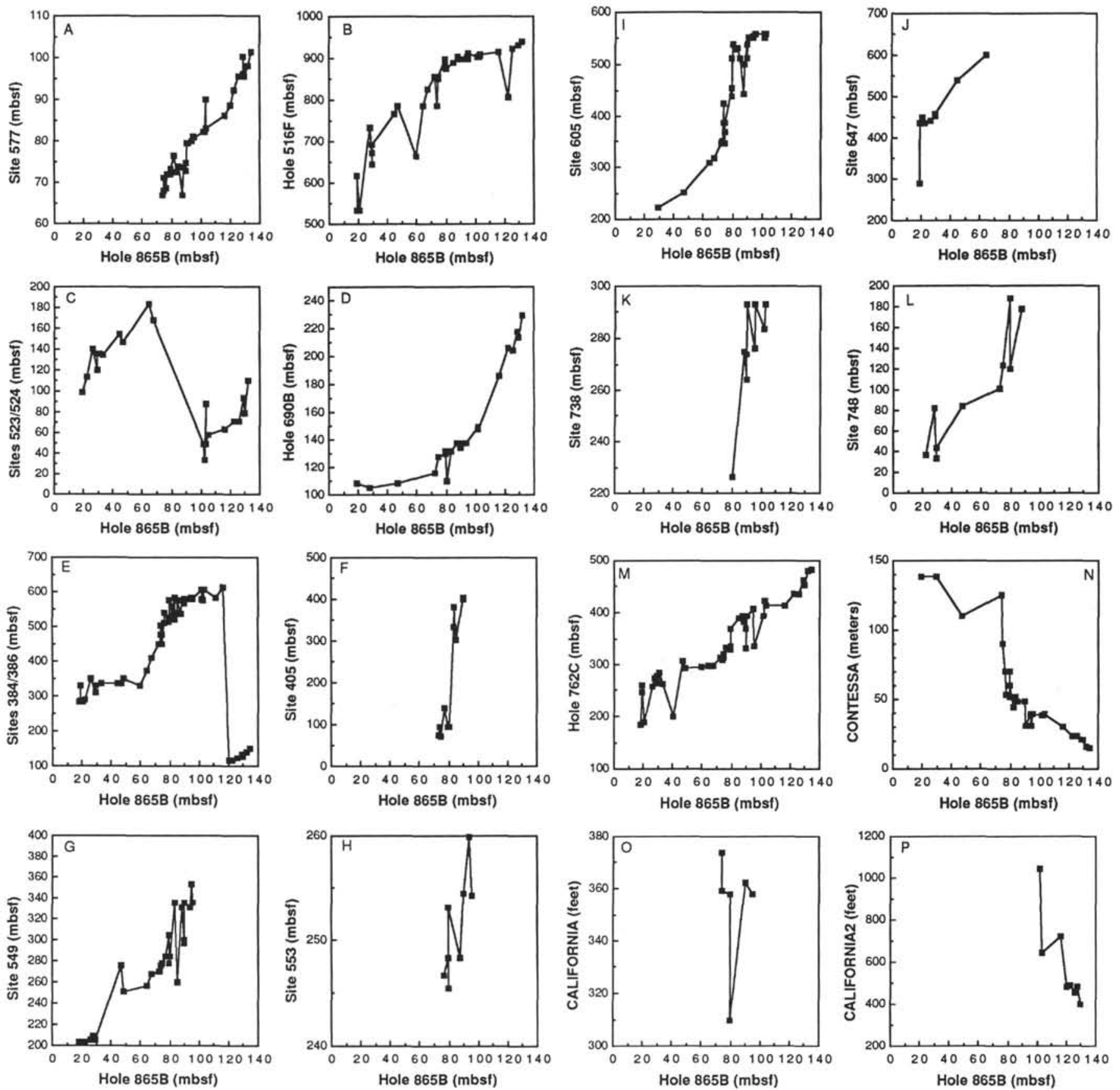

Figure 10. Meter level of more reliable Paleogene nannofossil biohorizons in Hole 865B vs. other DSDP/ODP sequences. Data are tabulated in Table 4. See text for more detailed discussion. Vertical lines in Figures $10 \mathrm{C}$ and $10 \mathrm{E}$ result from combination of two sections with different meter intervals.

577); the LO of Cruciplacolithus tenuis (low); and the FO and LO of T. gammation (low). In DSDP Hole 516F, the relative order of 29 of $38(76 \%)$ events agrees with that in Site 865 , assuming the correlation shown (Fig. 10B). Those events that differ significantly from this correlation include the LO of Heliolithus kleinpellii (high), the FO and LO of $C$. grandis (both low), the FOs of Discoaster saipanensis (high) and Bramletteius serraculoides (high), the LO of Sphenolithus furcatolithoides (low), and the FO of Reticulofenestra reticulata (low). At DSDP Sites 523 and 524, 19 out of 25 events (76\%) are consistent in order (Fig. 10C). Disparities include the LOs of Campylosphaera dela, Nannotetrina fulgens, and C. tenuis (all low). In ODP Hole 647 , the order of eight out of nine events ( $89 \%$ ) is consistent with that at Site 865 , with only the FO of Sphenolithus predistentus (low) differing. In ODP Hole 690B (Fig. 10D), the relative order of 20 out of 25 events $(80 \%)$ is similar to that at Site 865 . The three events differing most significantly with the correlation proposed include the FO of Reticulofenestra reticulata (high) and the LO of Toweius callosus (too high). Finally, in the Contessa section (Fig. $10 N), 21$ out of 32 events ( $66 \%$ ) are similar in order to that at Site 865 . Obvious disparities include the FOs of $D$. saipanensis and $D$. sublodoensis (too high), and the FO of $T$. gammation (low). All other sections, including those at Sites 386 (Fig. 10E), 549 (Fig. 10G), and 762 (Fig. 10M) possess intervals in which events are so scattered that it is not possible to determine the most consistent order. In these sections, however, several events clearly differ from the most consistent order. These include the FOs of D. saipanensis (Site 605: too low) and $C$. grandis (Sites 386, 605, and 762: all too low); the FO of Rhabdosphaera inflata (Site 386: too low); the FOs of $R$. dictyoda (Site 762: too low) and R. umbilicus (Site 549: too low); and the FO of Z. bijugatus (Site 762: too low). 
Several datums are disparate at more than one site. The level of the FO of $R$. dictyoda may differ significantly, according to the variable taxonomic concepts applied to this species (see Appendix). Determination of the level of $Z$. bijugatus may also vary as a result of taxonomic factors. Precursor holococcoliths not observed at Site 865 have been included in this species at Site 690 (J. Pospichal, pers. comm., 1993), for example. Other individual events that are thought to vary as a result of taxonomic disparities include the FOs of $B$. serraculoides, D. saipanensis, D. lodoensis, and $T$. gammation. Discussions of the suspected taxonomic differences are given in the Appendix. Further examination with uniform taxonomic concepts should resolve these disparities.

The significant difference in the relative position of the FO and LO of $C$. grandis and $R$. reticulata in Site 865 from that at other sections is not the result of taxonomic factors, but more likely the result of diachroneity caused by paleobiogeographic factors in these events. The former event is known to be diachronous by up to $1.5 \mathrm{~m} . \mathrm{y}$. in low-latitude and temperate sites (Wei and Wise, 1989). The latter event is thought to be a synchronous marker at mid-latitude sites (Wei and Wise, 1989), but the evidence presented here suggests that it may be diachronous between mid and low latitudes.

Our analysis indicated several interesting conclusions. The first is that correlation among different Paleogene sequences appears to be limited as much by taxonomic as by paleobiogeographic factors. The major departures from predicted order are dominantly FOs and LOs of species with taxonomic problems. On the other hand, consistency in the order of numerous events between Sites 865 and 690 suggests that many datums have the potential for correlation between low and high latitudes. An in-depth discussion of individual middle EoceneOligocene markers is presented in Wei and Wise (1992).

An important conclusion can be made regarding the stratigraphy of the section recovered at Site 865. The plots illustrated in Figure 10 show that the sedimentary sequence at Site 865 is as complete, if not more so, than any other section included in this analysis. In other words, the spread of the 72 datums representing approximately 25 m.y. through $130 \mathrm{~m}$ at Site 865 indicates that sedimentation was fairly continuous through time. As discussed previously, an exception to this is the unconformity correlating to Zone NP13 between 79 and 80 mbsf in both holes. This unconformity cannot be detected in Figure 10 because of the scale of the plots. However, we note that most other sequences are far more expanded in the interval correlating to $65-85$ mbsf in Hole 865B. The concentration of datums at particular levels in other sections indicates that they are characterized by significant condensed intervals and/or unconformities. Examples include the 72-74 mbsf interval at Site 577 (Fig. 10A: lower Eocene), the 900-910 mbsf interval in Hole 516F (Fig 10B: upper Paleocenelower Eocene), the 134-137 mbsf interval in Hole 690B (Fig. 10D: lower Eocene), the 577-579 mbsf interval at Site 386 (Fig 10E: upper Paleocene-lower Eocene), the 550-560 mbsf interval at Site 605 (Fig. 10I: upper Paleocene), the 292-297 mbsf interval in Hole $762 \mathrm{C}$ (Fig. 10M: middle Eocene), and the 38-39 meter interval at Contessa (Fig. 10N: upper Paleocene-lower Eocene). The absence of clustering of any group of datums at Site 865 relative to other sections (Fig. 10) suggests that no significant condensed intervals or unconformities occur in this section, even though the sedimentation rates are modest by comparison with those at several of the other sites (e.g., Sites 516 and 605). We have already discussed evidence for minor unconformities in Hole $865 \mathrm{~B}$ in the uppermost lower Eocene and at the Eocene/Oligocene boundary. We present data suggesting a possible minor unconformity in the uppermost Paleocene below.

The application of many of these previously unapplied secondary nannofossil biohorizons to Paleogene biostratigraphy and biochronology is promising. Using the scheme derived here, significantly higher resolution biostratigraphy is feasible; however, the order of events needs to be tested in other sequences. The main disadvantage of this approach is that precise determination of many of the events is time consuming.

\section{Detection of Reworking in Site 865}

The sedimentology of the Paleogene sequence at Site 865 indicates that winnowing of sediments on the seafloor is likely. The high relative abundance of planktonic foraminifers relative to finer particles, such as nannofossils and clay, suggests enrichment of coarse particles by bottom currents as lag deposits and removal of the fine fraction. The question is whether any reworking can be observed in the calcareous nannofossil biostratigraphy. Indeed, one classic Paleogene section at Site 690 on the Maud Rise has noticeable reworking of Paleocene fasciculiths into the Eocene sediments (Pospichal and Wise, 1990). This reworking also was observed at Site 762 (Siesser and Bralower, 1992).

To determine confidently the presence of reworking, the occurrence of a taxon outside of its true range must be established. This is not a simple problem. One method is to tabulate the range of all species (e.g., Table 3 ) and to observe differences in the order of events from those in other sites. As discussed in detail above, this is not a straightforward approach, as the order of many Paleogene events has not been determined conclusively. In general, it appears that the most significant departures in the order of the events determined at Site 865 from that compiled elsewhere (e.g., Perch-Nielsen, 1985; see Table 5) result from disparities in taxonomic concepts.

A second method for establishing reworking is to observe the distribution of a group of common nannofossils in the section above their true extinction level, as established by Pospichal and Wise (1990) in the Eocene section at Site 690. Interestingly, we observed almost no obvious evidence of such reworking in the Paleogene section at Site 865. We observed only one or two specimens of Fasciculithus in the lower Eocene section in both holes, and no cases of Toweius spp., Prinsius spp., or of such common species as Discoaster multiradiatus above their ranges. Possible exceptions are the few specimens of Chiasmolithus grandis and Nannotetrina fulgens observed in upper Eocene and lower Oligocene sediments (Zones CP15 and 16 ) in Hole $865 \mathrm{C}$ (Sections $143-865 \mathrm{C}-3 \mathrm{H}-4$ to $-4 \mathrm{H}-1$ ) several meters above their LO levels. However, in the cases of $C$. grandis, $N$. fulgens, and Fasciculithus, the number of specimens was so low that these occurrences could just as likely have resulted from contamination during sample handling as from reworking. More noticeable reworking has been observed in the planktonic foraminifer biostratigraphy of Hole 865B (I. Premoli Silva and W. Sliter, pers. comm., 1993).

We observed far more common evidence of downhole contamination compared to documented evidence of reworking, which we infer to have taken place during handling of the cores. Treatment of the cores during splitting was difficult as a result of their high water content, and it is possible that the saw blade contributed to some downhole contamination. To avoid this, we cleaned the top of all plug samples with a toothpick; however, in a handful of samples in each hole, we still observed an unmistakable, but infinitesimally small fraction (one or two specimens per slide), of nannofossils from higher up in the hole. The most noticeable cases of this contamination are specimens of Chiasmolithus grandis, Discoaster tanii, Sphenolithus furcatolithoides, Reticulofenestra dictyoda, and Triquetrorhabdulus inversus in lower Eocene sediments several tens of meters below their true FOs. Such downhole contamination is particularly noticeable at the tops of cores, particularly in Sections 143-865B-10H-1 and -12H1. We suggest that the tops of cores had higher water contents when recovered and that some downhole fluid flow may have transported these younger nannofossils. Evidence for the mechanism of contamination is that more out-of-place specimens were observed in samples prepared using toothpicks. We postulate that these samples were taken closer to the surface of the section where downhole contamination by the saw blade was greater. Even so, the number of the nannofossils suggests that this mechanism is insignificant.

Another enigma that continues to fascinate us is the differential preservation of calcareous nannofossils and planktonic foraminifers. In most pelagic sedimentary rocks of this age, planktonic foramini- 
Table 5. Comparison of nannofossil biohorizons.

\begin{tabular}{|c|c|c|c|c|c|c|c|c|}
\hline & & & & & Taxonc & & Paleo o & aphy \\
\hline Event & OB80 & M71 & PN85 & UN & DS & RS & Abun. & Geog. \\
\hline FAD E, subdisticha & & & NP20 & 1 & 1 & 2 & $\mathbf{R}$ & \\
\hline LAD R. reticulata & & & - & 2 & 2 & 2 & $\mathrm{R}$ & \\
\hline LAD $S$. spiniger & & & NP15T & 1 & 2 & 1 & $\mathbf{R}$ & \\
\hline LAD C. protoannulus & & & $\overline{10}$ & 2 & 2 & i & $\mathrm{F}$ & \\
\hline LAD D. barbadiensis & CP16B & NP21B & NP21B & $i$ & 1 & 1 & F & \\
\hline LAD D. saipanensis & CP16B & NP21B & NP21B & 1 & 1 & 2 & $\mathrm{R}$ & \\
\hline $\begin{array}{l}\text { LAD } S \text {, radians } \\
\text { FAD } H \text {. reticulata }\end{array}$ & & & NP19* & 2 & 2 & 1 & $\mathrm{R}$ & \\
\hline FAD $H$. reticulata & & & NP18 & 1 & 1 & 2 & $\mathrm{R}$ & \\
\hline $\begin{array}{l}\text { LAD C. grandis } \\
\text { FAD S, predistentus }\end{array}$ & CP15B & & NP17T & i & i & 2 & F & \\
\hline FAD S. predistentus & CA & & NP17 & 1 & i & 1 & $\mathrm{R}$ & \\
\hline FAD C. oamaruensis & & NP18B & NP18B & 1 & i & 2 & $\mathrm{R}$ & $\mathrm{H}$ \\
\hline LAD C. dela & & & NP16 & 1 & 1 & 2 & $\mathrm{~F}$ & \\
\hline FAD $R$. hillae & & & NP17 & 2 & 2 & 1 & $\mathrm{R}$ & \\
\hline $\begin{array}{l}\text { FAD } D \text {, nodifer } \\
\text { FAD } R \text {, reticulata }\end{array}$ & & & - & 2 & 2 & 1 & $\mathrm{R}$ & \\
\hline $\begin{array}{l}\text { FAD } R \text {. reticulata } \\
\text { FAD D bisectus }\end{array}$ & & & NP16 & 2 & 2 & 2 & $\mathrm{R}$ & \\
\hline FAD D. bisectus & & & NP16 & 2 & 2 & 1 & $\mathrm{~F}$ & \\
\hline LAD C. solitus & CP14bB & NP17B & NP17B & 1 & 1 & 2 & $\mathrm{R}$ & \\
\hline LAD S. obtusus & & & NP18 & 1 & 1 & 2 & $\mathrm{R}$ & \\
\hline LAD S. furcatolithoides & & & NP16 & 1 & 1 & 2 & F & \\
\hline LADC. nitidus & & & NP16 & i & 1 & 2 & $\mathrm{R}$ & \\
\hline LAD S. orphanknollensis & & & NP15 & i & 2 & 2 & $\mathrm{R}$ & \\
\hline LAD T. inversus & & & & 1 & 1 & 1 & C & \\
\hline FAD D. scrippsae & & & NP15 & 2 & 2 & 1 & C & \\
\hline FAD S. obtusus & & & NP16 & 1 & 1 & 2 & $\mathrm{R}$ & \\
\hline LAD C. medius & & & NP15 & 1 & 1 & 2 & $\mathrm{R}$ & \\
\hline LAD C. vanheckii & & & NP16 & 2 & 2 & 2 & $\ddot{R}$ & \\
\hline FAD S pseudoradians & & NP20B & NP15* & 2 & 2 & 1 & $\mathrm{R}$ & \\
\hline FAD $H$. heezenii & & & NP15 & 2 & 2 & 2 & $\mathrm{R}$ & \\
\hline LAD N. fulgens & & & NP15 & 2 & 2 & 2 & $\mathrm{R}$ & $\mathrm{N}$ \\
\hline FAD R. umbilicus & CP14aB & & NP15 & 2 & 2 & 1 & $\mathrm{~F}$ & \\
\hline LAD C. gigas & CP13cB & & NP15 & 1 & 1 & 2 & F & \\
\hline LAD L. rotundus & & & NP15 & 1 & 2 & 2 & R & \\
\hline FAD $H$. dinesenii & & & NP15 & 2 & 2 & 2 & $\hat{R}$ & \\
\hline FAD B. serraculoides & & & NP15 & 2 & 2 & 2 & $\mathrm{~F}$ & \\
\hline FAD $C$. medius & & & NP15 & $i$ & 1 & 2 & $\mathrm{R}$ & \\
\hline LAD L. mochloporus & & & NP15 & 2 & 2 & 2 & $\hat{R}$ & \\
\hline LAD S. stellatus & & & - & : & 1 & 2 & $\mathbf{R}$ & \\
\hline FAD S. furcatolithoides & & & NP15 & 1 & i & 2 & $\mathrm{~F}$ & \\
\hline LAD C. cribellum & & & NP11 & 2 & 2 & 2 & $\mathrm{R}$ & \\
\hline FAD C. gigas & CP13bB & & NP15 & 1 & 2 & 2 & $\mathrm{~F}$ & \\
\hline $\mathrm{LAD}$ E. lajollaensis & & & - & 1 & 1 & 2 & $\mathrm{R}$ & \\
\hline FAD D. "prenodifer" & & & NP15* & 2 & 2 & 2 & $\mathrm{~F}$ & \\
\hline FAD C. vanheckii & & & NP15 & 2 & 2 & 2 & $\mathrm{R}$ & \\
\hline LAD Neocrepidolithus sp. & & & - & 1 & 1 & 2 & $\mathrm{R}$ & \\
\hline FAD $L$. rotundus & & & NP15 & 2 & 2 & 2 & $\mathrm{R}$ & \\
\hline LAD S. editus & & & NP12 & 1 & 2 & $i$ & $\ddot{R}$ & \\
\hline LAD D. sublodoensis & & & NP15 & 2 & 1 & 2 & $\mathrm{~F}$ & \\
\hline FAD S, orphanknollensis & & & NP13 & 1 & 2 & 2 & $\mathrm{R}$ & \\
\hline FAD S. spiniger & & & NP14 & 1 & 2 & 1 & $\mathrm{R}$ & \\
\hline LAD $R$, inflata & CP13aB & & NP14 & i & 1 & 2 & $\mathbf{R}$ & $\mathrm{N}$ \\
\hline FAD $N$. fulgens & CP13aB & NP15B & NP15B & 2 & 2 & 2 & $\mathrm{R}$ & $\mathrm{N}$ \\
\hline FAD S. stellatus & & עס & & . & $i$ & 2 & $\ddot{R}$ & \\
\hline FAD D. saipanensis & & & NP15 & 1 & 2 & 2 & $\mathrm{~F}$ & \\
\hline FAD $R$. inflata & CP12bB & & NP14 & 1 & 1 & 2 & $\mathrm{R}$ & $\mathrm{N}$ \\
\hline LAD D. lodoensis & & & NP14 & 2 & 2 & 2 & $\hat{\mathrm{F}}$ & \\
\hline LAD T. gammation & & & NP15 & $i$ & 1 & 2 & $\mathrm{R}$ & \\
\hline LAD C. crassus & & & - & 2 & 2 & $i$ & R & \\
\hline FAD Cyclicargolithus sp. & & & - & 3 & 3 & 1 & $\mathrm{~F}$ & \\
\hline FAD E. insolita & & & - & : & 2 & 2 & $\mathrm{R}$ & \\
\hline LAD L. nascens & & & NP15 & 2 & 2 & 2 & $\mathrm{R}$ & \\
\hline FAD $T$. inversus & & & - & $i$ & 1 & 1 & $\mathrm{C}$ & \\
\hline FAD $C$. grandis & & & NP11* & $i$ & 1 & 1 & F & \\
\hline FAD D. sublodoensis & CP12B & NP14B & NP14B & 1 & 2 & 2 & $\mathrm{~F}$ & \\
\hline LAD $T$. orthostylus & & NP13B & NP13B & 1 & 2 & 1 & $\mathrm{R}$ & $\mathrm{N}$ \\
\hline LAD S conspicuus & & & NP12 & 1 & 2 & 2 & $\mathrm{R}$ & \\
\hline FAD H. lophota & & & NP12 & 1 & 1 & 2 & $\mathrm{R}$ & \\
\hline LAD T. callosus & & & NP15 & 1 & 2 & 2 & $\mathrm{~F}$ & \\
\hline FAD Nannotetrina sp. & & & - & : & 2 & 2 & $\mathrm{R}$ & $\mathrm{N}$ \\
\hline FAD $T$. gammation & & & NP11 & 1 & 1 & 2 & $\mathrm{R}$ & \\
\hline FAD D. deflandrei & & & NP11* & 1 & 2 & 1 & $\mathrm{R}$ & \\
\hline LAD C. eodela & & & NP10 & 2 & 3 & 2 & $\hat{R}$ & \\
\hline FAD C. nitidus & & & NP15 & 1 & 1 & 2 & $\hat{\mathrm{R}}$ & \\
\hline LAD T. eminens & & & NP10 & 2 & 2 & 2 & $\mathrm{~F}$ & \\
\hline FAD H. seminulum & & & NP12 & 1 & 1 & 2 & $\mathrm{R}$ & \\
\hline LAD T pertusus & & & NP12 & 2 & 2 & 2 & $\hat{R}$ & \\
\hline FAD L mochloporus & & & NP13 & 2 & 2 & 2 & $\hat{R}$ & \\
\hline FAD C. crassus & CP11B & & NP13 & 2 & 2 & 1 & $\hat{R}$ & \\
\hline FAD E. lajollaensis & & & - & 1 & 2 & 2 & $\hat{\mathrm{R}}$ & \\
\hline LAD N. protenus & & & NP12 & 2 & 2 & 2 & $\hat{R}$ & \\
\hline LAD E. macellus & & & NP12 & $i$ & $i$ & 2 & $\mathrm{R}$ & \\
\hline FAD C, cribellum & & & NP9 & 1 & 1 & 2 & $\hat{R}$ & \\
\hline FAD $R$. dictyoda & & & NP13 & 2 & 3 & 1 & $\mathrm{~F}$ & \\
\hline LAD S. anarrhopus & & & NP11* & 2 & 2 & 1 & $\mathrm{R}$ & \\
\hline LAD D multiradiatus & & & NP11 & $i$ & 2 & 1. & $\hat{R}$ & \\
\hline LAD Cruciplacolithus sp. & & & NP9 & 3 & 3 & 2 & $\mathrm{R}$ & \\
\hline FAD D. lodoensis & CP10B & NP12B & NP12B & 2 & 2 & 2 & $\mathrm{~F}$ & \\
\hline FAD $E$. formosa & & & NP12 & 2 & 3 & 1 & $\mathrm{~F}$ & \\
\hline FAD N. dubius & & & NP12 & 2 & 2 & 2 & $\mathrm{R}$ & \\
\hline
\end{tabular}


Table 5 (continued).

\begin{tabular}{|c|c|c|c|c|c|c|c|c|}
\hline \multirow[b]{2}{*}{ Event } & \multirow[b]{2}{*}{ OB80 } & \multirow[b]{2}{*}{ M71 } & \multirow[b]{2}{*}{ PN85 } & \multicolumn{3}{|c|}{ Taxonomy } & \multicolumn{2}{|c|}{ Paleogeography } \\
\hline & & & & UN & DS & RS & Abun. & Geog. \\
\hline FAD $S$. radians & & & NP11 & 1 & 2 & 1 & F & \\
\hline FAD C. protoannulus & & & - & 2 & 2 & 2 & $\mathrm{R}$ & \\
\hline LAD $T$, contortus(?) & $\mathrm{CP} 9 \mathrm{bB}$ & & NP10T & 1 & 3 & 2 & $\mathrm{R}$ & $\mathrm{N}$ \\
\hline FAD S. conspicuus & & & NP11 & 1 & 2 & 2 & $\hat{R}$ & \\
\hline FAD $T$. orthostylus & & & NP10 & 1 & 2 & 1 & $\mathrm{R}$ & $\mathrm{N}$ \\
\hline LAD $N$. junctus & & & NP10 & 2 & 2 & 2 & $\mathrm{R}$ & \\
\hline LAD T. bramlettei (?) & & & NP10 & $i$ & 3 & 2 & $\mathrm{R}$ & $\mathrm{N}$ \\
\hline FAD S. editus & & & NP11 & 1 & 2 & 1 & $\mathrm{~F}$ & \\
\hline LAD C. bidens & & & NP10 & 3 & 3 & 2 & $\mathrm{R}$ & \\
\hline LAD D. lenticularis & & & NP10 & 1 & 2 & 2 & $\hat{R}$ & \\
\hline LAD $P$. sigmoides & & & NP9 & 1 & 1 & 2 & $\mathrm{R}$ & \\
\hline LAD $C$, asymmetricus & & & - & 1 & i & 2 & $\ddot{R}$ & \\
\hline FAD D. barbadiensis & & & NP10 & 2 & 3 & 1 & $\mathrm{~F}$ & \\
\hline FAD T callosus & & & NP12 & 2 & 2 & 2 & $\mathrm{~F}$ & \\
\hline FAD T. contortus (?) & & & NP10 & 1 & 3 & 1 & $\mathrm{R}$ & \\
\hline LAD N. distentus & & & NP10 & i & 1 & 2 & $\hat{R}$ & \\
\hline LAD N. bukryi & & & NP9 & 1 & 1 & 2 & $\hat{R}$ & \\
\hline LAD N. perfectus & & & NP6 & 2 & 2 & 2 & $\hat{R}$ & \\
\hline LAD $P$. bisulcus & & & NP9 & $i$ & 2 & 1 & $\hat{R}$ & \\
\hline & & & - & i & 2 & 2 & $\hat{\mathrm{R}}$ & \\
\hline LAD $E$. distichus & & & - & 1 & 1 & 2 & $\mathrm{R}$ & \\
\hline FAD T. bramlettei (?) & CP9B & NP10B & NP10B & 1 & 3 & 2 & $\mathrm{R}$ & $\mathrm{N}$ \\
\hline LAD Fasciculithus spp. & & & NP9T & i & 1 & 1 & $\mathrm{R}$ & \\
\hline LAD F. tympaniformis & & & NP9T & 1 & 2 & 1 & $\vec{F}$ & \\
\hline FAD C. eograndis & & & NP10B & 1 & 2 & 2 & $\mathrm{R}$ & \\
\hline FAD Z. bijugatus & & & NP11 & 1 & 1 & 1 & $\hat{R}$ & \\
\hline LADC tenuis & & & NP9 & 1 & i & i & $\hat{R}$ & \\
\hline LAD D. mohleri & & & NP9 & 1 & 2 & i & $\mathrm{R}$ & \\
\hline FAD Ellipsolithus sp. & & & - & : & $=$ & 2 & $\mathrm{R}$ & \\
\hline LAD E. robusta & & & - & 2 & 2 & 2 & $\mathrm{~F}$ & \\
\hline FAD P. "prelarvalis" & & & - & ? & 1 & 2 & $\mathrm{R}$ & \\
\hline $\mathrm{LAD} C$. frequens & & & NP9 & 2 & 2 & 2 & $\mathrm{R}$ & \\
\hline FAD F. aubertae & & & NP9 & 2 & 3 & 2 & R & \\
\hline FAD L nascens & & & NP9 & 1 & 1 & 2 & $\hat{R}$ & \\
\hline FAD $C$, dela & & & NP10 & 2 & 2 & 2 & $\mathrm{R}$ & \\
\hline FAD D. lenticularis & & & NP9 & 1 & 2 & 2 & $\hat{R}$ & \\
\hline FAD $N$. junctus & & & NP7 & 2 & 2 & 2 & $\hat{R}$ & \\
\hline FAD $F$. lilianae & & & NP9 & 2 & 2 & 2 & $\hat{F}$ & \\
\hline FAD D, multiradiatus & CP8B & NP9B & NP9B & 1 & 1 & 1 & $\mathrm{~F}$ & \\
\hline LAD Prinsius spp. & & & NP4 & 2 & 1 & 2 & $\mathrm{~F}$ & \\
\hline FAD D, nobilis & СР7B & & NP8 & 2 & 2 & 1 & $\mathrm{~F}$ & \\
\hline LAD H. kleinpellii & & & NP9 & 1 & 1 & i & $\mathrm{R}$ & \\
\hline FAD C. eodela & CP8bB & & NP9 & 2 & 2 & 2 & $\hat{R}$ & \\
\hline FAD D. mohleri & CP6B & NP7B & NP7B & 2 & 2 & 1 & $\mathrm{R}$ & \\
\hline FAD E. macellus & CP3B & NP4B & NP4B & 1 & 1 & 2 & $\mathrm{R}$ & \\
\hline FAD $N$. distentus & & & NP8 & 1 & i & 2 & $\hat{\mathrm{R}}$ & \\
\hline LAD C. danicus & & & NP6 & 2 & 2 & 2 & $\mathbf{R}$ & \\
\hline FAD N. bukryi & & & NP8 & 1 & $i$ & 2 & $\mathrm{R}$ & \\
\hline FAD Neocrepidolithus sp. & & & - & 1 & 1 & 2 & $\ddot{R}$ & \\
\hline LAD F pileatus & & & NP5 & 1 & 2 & 1 & $\mathrm{R}$ & \\
\hline FAD $T$. eminens & & & NP7 & 2 & 2 & 2 & $\hat{F}$ & \\
\hline FAD C. asymmetricus & & & Nor & 1 & 1 & 2 & $\mathrm{R}$ & \\
\hline FAD H. kleinpellii & CP5B & NP6B & NP6B & $\mathrm{i}$ & 1 & 1 & $\mathrm{R}$ & \\
\hline FAD C. consuetus & & & NP5 & 2 & 1 & 2 & $\mathrm{R}$ & \\
\hline FAD C. nitescens & & & - & 2 & 2 & 2 & R & \\
\hline FAD S. anarrhopus & & & NP6 & 2 & 2 & 1 & $\mathrm{R}$ & \\
\hline FAD F. tympaniformis & CP4B & NP5B & NP5B & 1 & 1 & 1 & $\mathrm{~F}$ & \\
\hline FAD $F$, pileatus & & & NP4 & $i$ & 2 & 1 & $\mathrm{R}$ & \\
\hline
\end{tabular}

Notes: OB80 = Bukry $(1973,1975 \mathrm{a}, 1975 \mathrm{~b})$ and Okada and Bukry $(1980), \mathrm{M} 71=$ Martini $(1971)$, and PN85 = Perch-Nielsen (1985). B = event is zonal marker of base of zone, and $\mathrm{T}=$ event lies at top of zone. An asterisk $\left({ }^{*}\right)$ indicates sporadic distribution toward end of range. Under "Taxonomy" column, $\mathrm{UN}=$ uniformity of species concepts among different workers (from 1, strongly uniform, to 3 , strongly variable), DS = distinctiveness of taxon from similar forms (from 1, distinctive, to 3, gradational), and RS = resistance to dissolution (from 1, resistant, to 3, susceptible). Under "Paleogeography" column, Abun. = relative abundance toward end of range (same terms as Table 2 and Fig. 4), and Geog. = paleobiogeographic factors affecting ranges $(\mathrm{H}=$ high-latitude species, and $\mathrm{N}=$ neritic species).

fers and calcareous nannofossils have been affected by overgrowth and etching to a similar degree. Planktonic foraminifers are, if anything, slightly more susceptible to diagenetic alteration than are calcareous nannofossils (e.g., Schlanger and Douglas, 1974). In Paleogene sediments from Site 865 , however, nannofossils tended to be affected by a minor amount of etching and a significant amount of overgrowth, whereas planktonic foraminifers generally were in nearly pristine condition.

\section{Correlation with Planktonic Foraminifer Biostratigraphy}

Currently applied Paleogene planktonic foraminifer zonations are the culmination of several decades of study (e.g., Berggren, 1969; Blow, 1979; Berggren and Miller, 1988; Berggren et al., in press). Correlation between these zonations and those of calcareous nan- noplankton, however, are less well known. As discussed by Berggren et al. (1985), such correlations have been established only in a few sites. Many deep-sea sequences either are poorly recovered or are known to be incomplete. Shelf sections commonly suffer from the latter problem (e.g., Aubry et al., 1988). Some of the most complete sequences are in high-latitude areas, where standard markers of one or both groups are not present (e.g., Pospichal and Wise, 1990; Stott and Kennett, 1990; Aubry, 1992b). Several DSDP/ODP sections were subjected to only preliminary shipboard investigations and have not been subsequently studied in detail. Because the Paleogene sequence at Site 865 is largely complete, such correlations should be without the stratigraphic problems that affect these correlations in other sections, even though biostratigraphic problems do exist.

Preliminary planktonic foraminifer biostratigraphy has been conducted on Hole 865 B by I. Premoli Silva and W. Sliter (pers. comm., 


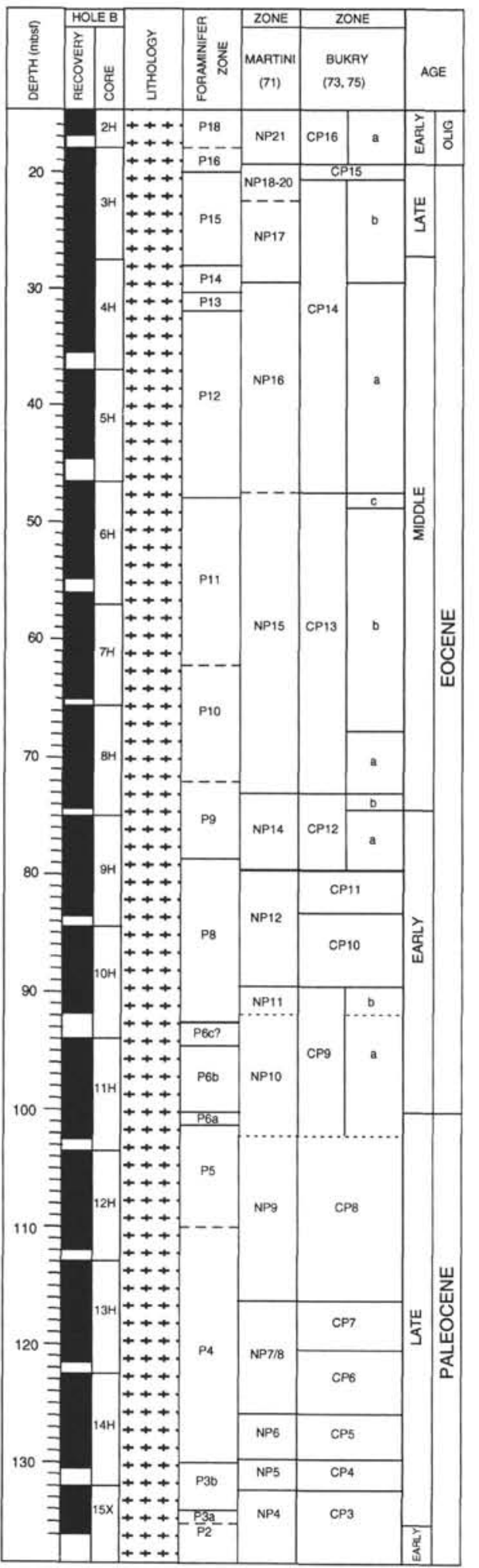

Figure 11. Correlation of calcareous nannofossil and planktonic foraminifer biostratigraphy of Hole 865B. Planktonic foraminifer biostratigraphy is after I. Premoli Silva and W. Sliter (pers. comm., 1993). Zonation applied is the scheme of Berggren and Miller (1988). Long dashed zonal boundaries show those determined indirectly using secondary markers; short boundaries are based upon tentative identifications of species of Tribrachiatus. Bold lines show positions of known unconformities.
1993). These authors paid close attention to zonal boundaries that were determined with precision (Fig. 11). Several upper Paleocene to middle Eocene planktonic foraminifer zones could not be determined directly, as boundary markers were rare or absent. The boundaries of these zones have been established using the ranges of secondary markers that have been correlated to the markers at other sites. The zones that have been identified based on secondary markers include the base of upper Paleocene Zone P4, the base of upper Paleocene Zone P5, the base of middle Eocene Zone P10, and the base of middle Eocene Zone P11.

In general, the correlation of both the Martini (1971) and Bukry $(1973,1975 b)$ nannofossil zones determined in this investigation with the planktonic foraminifer zones of Berggren and Miller (1988) in Hole 865B are similar to those shown in the Paleogene chronostratigraphy of Berggren et al. (1985) (Fig. 11). In this section, we discuss reasons for the differences, which are concentrated in the lower and middle Eocene. There are five disparities.

1. The base of nannofossil Subzone CP13b, which is based on the FO of $C$. gigas, correlates to foraminifer Zone P10 in Hole $865 \mathrm{~B}$, but to P11 in Berggren et al. (1985). Three possible explanations exist for this disparity: (1) we have included in $C$. gigas a morphotype that occurs in the early part of its range, and this morphotype, which bears a small cross, has not been previously described (see Appendix for discussion); hence, it is possible that the range given here for $C$. gigas is longer than that established in other sequences; (2) the FO of $C$. gigas is diachronous, as established by Wei and Wise (1989); and (3) the boundary between Zones P10 and P11 has been determined indirectly (i.e., not with the original zonal marker), and it is possible that the secondary marker does not provide a precise determination of this zonal boundary.

2. The bases of Zones CP13 and NP15 correlate with Zone P9 in Hole 865B, but with P10 in Berggren et al. (1985). We think that the correlation of Berggren et al. (1985) is probably more accurate, as the range of markers of these nannofossil zones may be different at Site 865 than it is elsewhere (see discussion of Nannotetrina fulgens and Rhabdosphaera inflata in Zones CP12 and CP13 above).

3. The base of Zones CP9 and NP10 correlates to Zone P5 in Hole $865 \mathrm{~B}$, but to the boundary between Subzones P6a and P6b (subzonal definitions of Berggren and Miller (1988) (Paleocene/Eocene boundary) in Berggren et al. (1985). A similar correlation to that established at Site 865 had been previously proposed by Aubry et al. (1988) and Berggren and Aubry (in press) (see discussion below).

4. The base of Zones CP5 and NP6, defined by the FO of Heliolithus kleinpellii, correlates to the lower part of Subzone P4 in Hole 865B, but just below this level in Subzone P3b in Berggren et al. (1985). This minor difference may result from incomplete recovery at the base of Core 143-865B-14H (Fig. 11) or the use of a secondary foraminifer marker. Alternatively, the FO of $\mathrm{H}$. kleinpellii is thought to be diachronous (Wei and Wise, 1989).

5. The base of Zones CP4 and NP5, defined by the FO of Fasciculithus tympaniformis, lies in Subzone P3b in Hole 865B, but between Subzones P3a and P3b in Berggren et al. (1985). We have no possible explanations for this minor discrepancy.

\section{Implications for Sedimentation History and Rate}

The most important stratigraphic questions to be addressed are

1. Is the Paleogene section recovered at Site 865 complete?

2. What were the sedimentation rates compared to other Paleogene sections that have been the subject of paleoceanographic investigations?

It is much more difficult to establish that a section is complete than it is to determine hiatuses in sedimentation. One method to compare both completeness and rates of sedimentation relative to other sites is 
to plot the meter levels of the same events in two sections, as described by Shaw (1964). Figure 10 shows plots of the meter levels of numerous events in Hole 865B and various other Paleogene sequences. The fact that few "clusters" of events correspond to significant stratigraphic intervals in these other sections suggests, in general, that the Paleogene section as a whole at Site 865 appears to be as complete as any other section yet recovered. An exception to this is the unconformity correlating to Zone NP13 in the uppermost lower Eocene (Fig. 5). It is clear that many other Paleogene sedimentary sequences, particularly those from continental margins, were characterized by far higher overall sedimentation rates.

To calculate sedimentation rates, we used the ages of nannofossil zonal events that were provided by Berggren et al. (1985) and updated by Wei and Wise (1989). A plot of sedimentation rate through the Paleogene in Hole 865B is illustrated in Figure 12. This shows that moderate rates $(3-8 \mathrm{~m} / \mathrm{m}$.y.) persisted throughout the late Paleocene and early Eocene. A brief interval in the late early Eocene and early middle Eocene (e.g., Zones NP13-NP14 or Zones CP11-CP12) was characterized by a hiatus or slower sedimentation rates $(0-1.5 \mathrm{~m} / \mathrm{m} . \mathrm{y}$.). Moderate sedimentation rates resumed in the middle and early part of the late Eocene. An interval of slow sedimentation $(0.2 \mathrm{~m} / \mathrm{m}$.y.) occurred in the late Eocene between 37 and $40 \mathrm{Ma}$.

\section{Calcareous Nannofossils and Paleocene/Eocene Boundary Events}

A great amount of attention has been directed at paleoceanographic events surrounding the Paleocene/Eocene boundary. This interval is associated with a rapid warming of high-latitude surface waters and deep waters from all different locations and extinction of a variety of different epifaunal benthic foraminifers accompanied by a marked excursion in the carbon isotopic record (e.g., Tjalsma and Lohmann, 1983; Shackleton, 1986; Kennett and Stott, 1991). All of these events have also been recognized in Holes 865B and 865C (Bralower et al., unpubl. data). Because of the considerable interest in this time period, it is essential to correlate biostratigraphic events, both nannofossil and planktonic foraminifer, in a number of different sections precisely.

The exact definition of the Paleocene/Eocene boundary has been somewhat controversial. This complicated issue has been discussed in detail by Aubry et al. (1986, 1988), Berggren et al. (1985, in press), and Berggren and Aubry (in press). In the deep sea, the Paleocene/Eocene boundary has traditionally been placed at the LO of the planktonic foraminifer Morozovella velascoensis, which defines the boundary between Subzones P6a and P6b (Berggren and Miller, 1988). In terms of nannofossil zones, this boundary has, until recently, been placed between Zones NP9 and NP10 (e.g., Martini, 1971). Based on combined lithostratigraphy/biostratigraphy in stratotype and parastratotype sequences in northwestern Europe, Aubry et al. (1988) suggested that the Paleocene/Eocene boundary be raised above its traditional placement to within Zone NP10.

In Site 865, the LO of M. velascoensis lies between Samples 143-865B-11H-5, 130-132 cm (101.30 mbsf), and - $11 \mathrm{H}-5,50-52 \mathrm{~cm}$ (100.50 mbsf), and between Samples 143-865C-12 H-1, 111-113 cm (99.42 mbsf), and $-11 \mathrm{H}-5,130-132 \mathrm{~cm}$ (96.10 mbsf) (Fig. 11; I. Premoli Silva and W. Sliter, pers. comm., 1993). The late Paleocene benthic extinction event lies several meters below this in most sites, including both Holes $865 \mathrm{~B}$ and $865 \mathrm{C}$ (between 103.5 and $103.6 \mathrm{mbsf}$ in Hole 865B, and between 102.9 and 103.0 mbsf in Hole 865C; Bralower et al., unpubl. data). As discussed previously, the most distinctive nannofossil event in this interval is the LO of a dominant group of Paleocene nannoliths, the fasciculiths. This group occurs in all of the apparently complete Paleocene/Eocene boundary sequences and is common to abundant, so its extinction is a recognizable event that can be precisely determined.

The sequence of nannofossil events close to the Paleocene/Eocene boundary is shown in Figure 7. A drastic reduction in abundance of the fasciculiths occurs between Samples 143-865B-12H-1, 4-6 cm

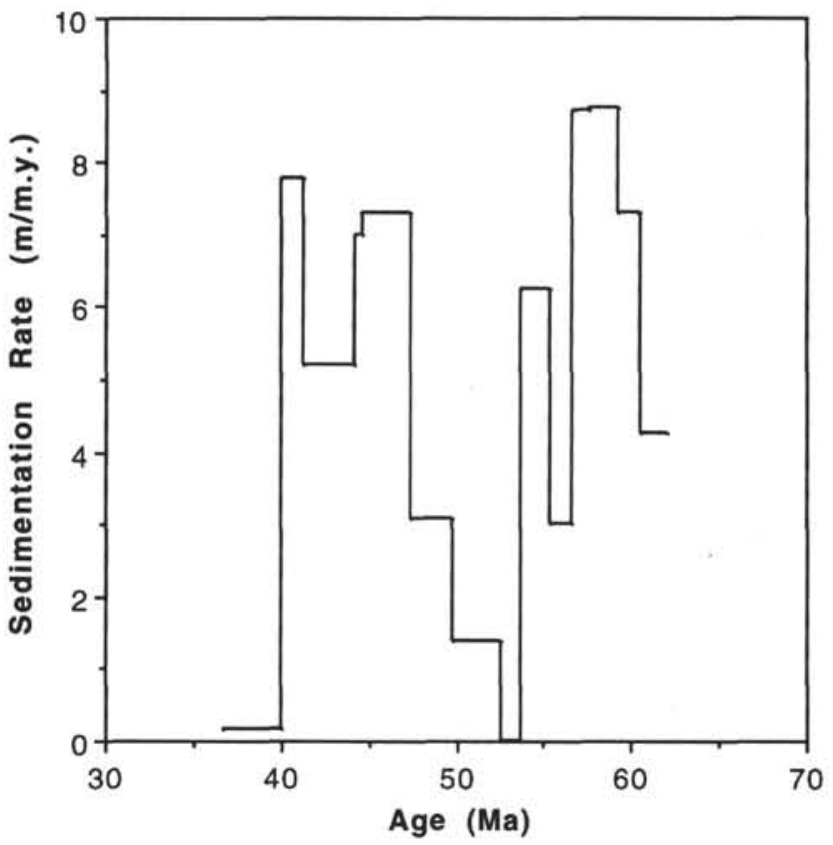

Figure 12. Plot of sedimentation rate through time in Hole $865 \mathrm{~B}$ as indicated by nannofossil biostratigraphy. Absolute ages of events are taken from Berggren et al. (1985) as updated by Wei and Wise (1989).

(103.54 mbsf), and $-11 \mathrm{H}-\mathrm{CC}, 2-3 \mathrm{~cm}$ (102.50 mbsf), and between $143-865 \mathrm{C}-12 \mathrm{H}-4,50-52 \mathrm{~cm}(103.30 \mathrm{mbsf})$, and $-12 \mathrm{H}-4,20-22 \mathrm{~cm}$ (102.90 mbsf). The final extinction of this species occurs in Samples $143-865 \mathrm{~B}-11 \mathrm{H}-6,70-72 \mathrm{~cm}$ (102.20 mbsf), and 143-865C-12H-2, $110-112 \mathrm{~cm}$ ( $100.90 \mathrm{mbsf})$, although occurrences above the dramatic reduction in abundance are possibly reworked. The dramatic reduction of this genus correlates almost exactly with the carbon isotopic excursion, a correlation that has not been previously recognized. Other nannofossil events in the boundary interval (Fig. 7) include the LOs of Cruciplacolithus tenuis and Discoaster mohleri and the FOs of Zygrhablithus bijugatus, Chiasmolithus eograndis, and possible specimens of Tribrachiatus bramlettei.

The nearest site with which to compare the order of these events is Site 577 . Here, the LO of M. velascoensis has been placed at Sample 577-9-6, $135 \mathrm{~cm}$ (82.25 mbsf) (D. Pak, pers. comm., 1993), which is consistent with the biostratigraphy of Miller et al. (1987). In this site, the reduction in the abundance of the fasciculiths occurs between Sample 577-10-1, 36-37 cm (83.16 mbsf), and 577-9-CC, 8-9 cm $(82.28 \mathrm{mbsf})$ with the final extinction of this group lying between $577-9-6,120-121 \mathrm{~cm}(82.10 \mathrm{mbsf})$, and 577-9-6, 92-94 cm (81.82 mbsf) (Monechi, 1985; and our own observations). Thus, in both Sites 577 and 865, the decrease in relative abundance of the fasciculiths occurs below the $\mathrm{LO}$ of $M$. velascoensis, but the relative position of the LO of the fasciculiths lies below this event in Site 865, but not in Site 577. We tentatively explain this difference as a result of minor reworking of the fine fraction in Site 577 . Because the boundary interval in this site is so condensed, the order of these events appears to have been reversed by minor reworking, or by normal bioturbation.

Identification of the Paleocene/Eocene boundary using calcareous nannofossil biostratigraphy is difficult. Originally, two events, the FOs of Discoaster diastypus and T. bramlettei, were used to locate this boundary (e.g., see discussion in Martini, 1971; Aubry, 1983; Perch-Nielsen, 1985). Considerable overgrowth prevents confident identification of $D$. diastypus and $T$. bramlettei in Site 865 material. The latter species has been tentatively identified (see Appendix for full discussion). If its range is accurate, then the original nannofossil definition of the Paleocene/Eocene boundary (e.g., Martini, 1971) lies somewhat below the foraminifer definition. The FO of the form 
that we have identified as $T$. bramlettei lies between 102.20 and $102.50 \mathrm{mbsf}$ in Hole 865B (between Sample 143-865B-11H-6, $70 \mathrm{~cm}$, and $-11 \mathrm{H}-\mathrm{CC}, 2 \mathrm{~cm}$ ) and between 102.68 and $103.00 \mathrm{mbsf}$ in Hole $865 \mathrm{C}$ (between Sample 143-865C-12H-3, $138 \mathrm{~cm}$, and - $12 \mathrm{H}-4,20$ $\mathrm{cm}$ ). The LO of $M$. velascoensis (boundary between planktonic foraminifer Subzones P6a and P6b of Berggren and Miller [1988]) lies between 101.30 and 100.50 mbsf in Hole $865 \mathrm{~B}$ and between 99.42 and 96.10 mbsf in Hole $865 \mathrm{C}$. Therefore, placement of the Paleocene/Eocene boundary within nannofossil Zone NP10 at Site 865 (Fig. 11) is consistent with the conclusion of Aubry et al. (1988).

Few other sections exist with which to compare this order. Morozovella velascoensis is a low-latitude taxon that has only rarely been observed in high-latitude sites (e.g., Stott and Kennett, 1990). Conversely, where the range of this foraminifer has been established, that of $T$. bramlette i is often restricted. At Site 577, for example, T. bramlettei was not positively identified (Monechi, 1985). At this latter site, however, the FO of common $D$. diastypus lies over $1 \mathrm{~m}$ above the LO of $M$. velascoensis (Monechi, 1985; Backman, 1986; Miller et al., 1987). At Site 690, the FO of T. bramlettei and the LO of the fasciculiths lie 21 and 23 meters above the level of the benthic extinction and carbon isotopic shift, respectively (Pospichal and Wise, 1990; Thomas, 1990; Kennett and Stott, 1991). At Site 865, however, these events almost overlap. Although the potential for reworking is present at Site 690 (e.g., Pospichal and Wise, 1990), which could have raised the level of the LO of the fasciculiths, this cannot explain the 21 -m gap between the FO of $T$. bramlettei and the benthic extinction. These events apparently lie within $1 \mathrm{~m}$ at Site 865 , indicating the possibility of a minor unconformity right above the benthic extinction level. Alternatively, the possibility exists that major differences occur in the relative ranges of taxa between high and low latitudes. This topic will need further rigorous investigation.

Obviously, our knowledge of the biostratigraphy of the Paleocene/ Eocene boundary interval in the deep sea will benefit greatly from the recovery of additional sequences that possess standard nannofossil and planktonic foraminifer marker taxa.

\section{CONCLUSIONS}

A relatively expanded and largely complete upper Paleocene to lower Oligocene sequence was recovered from the pelagic cap overlying Allison Guyot, Mid-Pacific Mountains. Calcareous nannofossils are moderately well preserved and diverse throughout the sequence recovered, which extends from nannofossil Zones CP3 to CP16. Most traditional zonal markers are present; however, the rarity of several of them, particularly discoasters, and the overgrowth of others, including species of Tribrachiatus, in the uppermost Paleocene and lower Eocene sections makes zonal subdivision of part of this sequence difficult. Currently, unobserved gradational forms in nannofossil lineages indicate that parts of this sequence are more expanded than any other yet recovered.

Considerable attention has been paid to establishing the precise range of nonzonal biohorizons that can be determined in this section. About 142 zonal and nonzonal events were determined in the Paleogene section. Although these events are spread out fairly evenly throughout the section, some of the most dramatic turnovers can be observed in the boundary and early Eocene interval. Establishment of these biohorizons provides promise for future high-resolution Paleogene biostratigraphic studies.

Comparison with other sites suggests that sedimentation was continuous throughout the Paleogene at Site 865; however, sedimentation rate calculations indicate an interval of nondeposition interspersed with slow sedimentation in the late early and early middle Eocene. Identification of the Paleocene/Eocene boundary using nannofossil biostratigraphy proved to be impossible as no distinctive nannofossil events correlate with the LO of the planktonic foraminifer, Morozovella velascoensis, which has been used commonly to define this boundary in the deep sea. This boundary appears to lie within nannofossil Zone NP10 as suggested by Aubry et al. (1988).

\section{ACKNOWLEDGMENTS}

The authors gratefully acknowledge the significant contribution of John Firth in discussions of species concepts and microscope identifications, and Paleogene stratigraphic problems during Leg 143. We thank Marie-Pierre Aubry, Jan Backman, Jim Pospichal, and Bill Siesser for similar shore-based assistance, and Isabella Premoli Silva and Bill Sliter for sharing their unpublished planktonic foraminifer biostratigraphic data. We are grateful to Jan Backman, John Firth, Giuliana Villa, and Jerry Winterer for thorough reviews of the original manuscript. This study would not have been possible without the excellent compilations of Paleogene nannofossils published by MariePierre Aubry and Katharina von Salis Perch-Nielsen. We are grateful to both of them. We acknowledge the assistance of Matthew Parrow and Sarah Mock with smear-slide preparation. Lastly, we are extremely grateful to Co-Chiefs Will Sager and Jerry Winterer for yielding to our pressure and drilling the second APC section at Site 865. This research was funded by JOI-USSAC.

\section{REFERENCES}

Applegate, J.L., and Wise, S.W., Jr., 1987. Eocene calcareous nannofossils, Deep Sea Drilling Project Site 605, upper continental rise off New Jersey U.S.A. In van Hinte, J.E., Wise, S.W., Jr., et al., Init. Repts. DSDP, 93: Washington (U.S. Govt. Printing Office), 685-698.

Aubry, M.-P., 1983. Corrélations biostratigraphiques entre les formations paléogènes épicontinentales de l'Europe du Nord-Ouest, basées sur la nannoplankton calcaire [Thése]. Univ. Pierre et Marie Curie.

1984. Handbook of Cenozoic Calcareous Nannoplankton. Book I Ortholithae (Discoasters): New York (Micropaleontology Press, American Museum of Natural History).

1986. Paleogene calcareous nannoplankton biochronology of Northwestern Europe. Palaeogeogr., Palaeoclimatol., Palaeoecol., $55: 267-334$.

1988. Handbook of Cenozoic Calcareous Nannoplankton (Book 2): Ortholithae (Holococcoliths, Ceratoliths, Ortholiths and Others): New York (Micropaleontology Press, American Museum of Natural History). 1989. Handbook of Cenozoic Calcareous Nannoplankton (Book 3): Ortholithae (Pentaliths and Others). Heliolithae (Fasciculiths, Sphenoliths, and Others): New York (Micropaleontology Press).

, 1990. Handbook of Cenozoic Calcareous Nannoplankton (Book 4): Heliolithae (Helicoliths, Cribriliths, Lopadoliths, and Others): New York (Micropaleontology Press, American Museum of Natural History). , 1992a. Late Paleogene calcareous nannoplankton evolution: a tale of climatic deterioration. In Prothero, D.R., and Berggren, W.A. (Eds.), Eocene-Oligocene Climatic and Biotic Evolution: Princeton, NJ (Princeton University Press), 272-309.

, 1992b. Paleogene calcareous nannofossils from the Kerguelen Plateau, Leg 120. In Wise, S.W., Jr., Schlich, R., et al., Proc. ODP, Sci. Results, 120: College Station, TX (Ocean Drilling Program), 471-491.

Aubry, M.-P., Berggren, W.A., Kent, D.V., Flynn, J.J., Klitgord, K.D., Obradovich, J.D., and Prothero, D.R., 1988. Paleogene geochronology: an integrated approach. Paleoceanography, 3:707-742.

Aubry, M.-P., Hailwood, E.A., and Townsend, H.A., 1986. Magnetic and calcareous nannofossil stratigraphy of the lower Paleogene formations of the Hampshire and London Basins. J. Geol. Soc. London, 143:729-735.

Backman, J., 1984. Cenozoic calcareous nannofossil biostratigraphy from the northeastern Atlantic Ocean-Deep Sea Drilling Project Leg 81. In Roberts, D.G., and Schnitker, D., et al., Init. Repts. DSDP, 81: Washington (U.S. Govt. Printing Office), 403-428.

1986. Late Paleocene to middle Eocene calcareous nannofossil biochronology from the Shatsky Rise, Walvis Ridge and Italy. Palaeogeogr., Palaeoclimatol., Palaeoecol., 57:43-59.

\footnotetext{
Abbreviations for names of organizations and publications in ODP reference lists follow the style given in Chemical Abstracts Service Source Index (published by American Chemical Society).
} 
1987. Quantitative calcareous nannofossil biochronology of middle Eocene through early Oligocene sediment from DSDP Sites 522 and 523. Abh. Geol. Bundesanst. (Austria), 39:21-31.

Backman, J., and Hermelin, J.O.R., 1986. Morphometry of the Eocene nannofossil Reticulofenestra umbilicus lineage and its biochronological consequences. Palaeogeogr., Palaeoclimatol., Palaeoecol., 57:103-116.

Berggren, W.A., 1969. Rates of evolution in some Cenozoic planktonic foraminifera. Micropaleontology, 15:351-365.

Berggren, W.A., and Aubry, M.-P., in press. A late Paleocene-early Eocene NW European and North Sea magnetobiostratigraphic correlation network: a sequence stratigraphic approach.

Berggren, W.A., Kent, D.V., and Flynn, J.J., 1985. Jurassic to Paleogene: Part 2. Paleogene geochronology and chronostratigraphy. In Snelling, N.J. (Ed.), The Chronology of the Geological Record. Geol. Soc. London Mem. 10:141-195.

Berggren, W.A., Kent, D.V., Swisher, C.C., III, and Miller, K.G., in press. A revised Paleogene geochronology and chronostratigraphy. In Berggren, W.A., Kent, D.V., and Hardenbol, J. (Eds.), Soc. Econ. Paleontol. Mineral.

Berggren, W.A., and Miller, K.G., 1988. Paleogene tropical planktonic foraminiferal biostratigraphy and magnetobiochronology. Micropaleontology, $34: 362-380$

Blow, W.H., 1969. Late middle Eocene to Recent planktonic foraminiferal biostratigraphy. In Brönniman, P., and Renz, H.H. (Eds.), Proc. First Int. Conf. Planktonic Microfossils, Geneva, 1967: Leiden (E.J. Brill), 1:199-422. , 1979. The Cainozoic Globigerinida: Leiden (E.J. Brill).

Bralower, T.J., Sliter, W.V., Arthur, M.A., Leckie, R.M., Allard, D.J., and Schlanger, S.O., 1993. Dysoxic/anoxic episodes in the Aptian-Albian (Early Cretaceous). In Pringle, M.S., Sager, W.W., Sliter, M.V., and Stein, S. (Eds.), The Mesozoic Pacific: Geology, Tectonics, and Volcanism. Am. Geophys. Union, Geophys. Monogr., 77:5-37.

Bramlette, M.N., and Sullivan, F.R., 1961. Coccolithophorids and related nannoplankton of the early Tertiary in California. Micropaleontology: 7:129-188.

Bukry, D., 1973. Low-latitude coccolith biostratigraphic zonation. In Edgar, N.T., Saunders, J.B., et al., Init. Repts. DSDP, 15: Washington (U.S. Govt. Printing Office), 685-703.

_ 1975a. Biostratigraphy of Cenozoic marine sediment by calcareous nannofossils. Micropaleontology, 24:44-60.

1975b. Coccolith and silicoflagellate stratigraphy, northwestern Pacific Ocean, Deep Sea Drilling Project Leg 32. In Larson, R.L., Moberly, R., et al., Init. Repts. DSDP, 32: Washington (U.S. Govt. Printing Office), $677-701$.

Filewicz, M.V., and Hill, M.E., 1983. Calcareous nannofossil biostratigraphy of the Santa Susana and Llajas Formations, north side Simi Valley. In Squires, R.L., Filewicz, M.V. (Eds.), Cenozoic Geology of the Simi Valley Area, United States. Pac. Sect., Soc. Econ. Paleontol. Mineral., Fieldtrip Guidebook, 45-60.

Firth, J.V., 1989. Eocene and Oligocene calcareous nannofossils from the Labrador Sea, ODP Leg 105. In Srivastava, S. P., Arthur, M.A., Clement, B.,et al., Proc. ODP, Sci. Results, 105: College Station, TX (Ocean Drilling Program), 263-286.

Gartner, S., Jr., 1970. Phylogenetic lineages in the Lower Tertiary coccolith genus Chiasmolithus. Proc. North Am. Paleontol. Conv., Sept. 1969, G: 930-957.

- Jr., 1971. Calcareous nannofossils from the JOIDES Blake Plateau cores, and revision of Paleogene nannofossil zonation. Tulane Stud. Geol. Paleontol., 8:101-121.

Haq, B.U., 1973. Transgressions, climatic change and the diversity of calcareous nannoplankton. Mar. Geol., 15:25-30.

Haq, B.U., and Lohmann, G.P., 1976. Early Cenozoic calcareous nannoplankton biogeography of the Atlantic Ocean. Mar. Micropaleontol., 1:119-194.

Hay, W.W., and Mohler, H.P., 1967. Calcareous nannoplankton from early Tertiary rocks at Pont Labau, France, and Paleocene-Eocene correlations. J. Paleontol., 41:1505-1541.

Hay, W.W., Mohler, H.P., Roth, P.H., Schmidt, R.R., Boudreaux, J.E., 1967. Calcareous nannoplankton zonation of the Cenozoic of the Gulf Coast and Caribbean-Antillean area, and transoceanic correlation. Trans. Gulf Coast Assoc. Geol. Soc., 17:428-480.

Hay, W.W., and Steinmetz, J.C., 1973. Probabilistic analysis of distribution of late Paleocene-early Eocene calcareous nannofossils. Proc. Soc. Econ. Paleontol. Mineral. Calcareous Nannofossil Symp., 58-70.

Heath, G.R., Burckle, L.H., et al., 1985. Init. Repts. DSDP, 86: Washington (U.S. Govt. Printing Office).
Hekel, H., 1968. Nannoplanktonhorizonte und tektonische Strukturen in der Flyschzone nördlich von Wien (Bisambergzug). Jb. Geol. Bundesanst. Austria, 3: 293-337.

Kennett, J.P., and Stott, L.D., 1991. Abrupt deep-sea warming, paleoceanographic changes and benthic extinctions at the end of the Palaeocene. Nature, 353:225-229.

Lonsdale, P., Normark, W.R., and Newman, W.A., 1972. Sedimentation and erosion on Horizon Guyot. Geol. Soc. Am. Bull., 83: 289-315.

Martini, E., 1971. Standard Tertiary and Quaternary calcareous nannoplankton zonation. In Farinacci, A. (Ed.), Proc. 2nd Int. Conf. Planktonic Microfossils Roma: Rome (Ed. Tecnosci.), 2:739-785.

Miller, K.G., Janecek, T.R., Katz, M.E., and Keil, D.J., 1987. Abyssal circulation and benthic foraminiferal changes near the Paleocene/Eocene boundary. Paleoceanography, 2:741-761.

Monechi, S., 1985. Campanian to Pleistocene calcareous nannofossil stratigraphy from the northwest Pacific Ocean, Deep Sea Drilling Project Leg 86. In Heath, G.R., Burckle, L.H., et al., Init. Repts. DSDP, 86: Washington (U.S. Govt. Printing Office), 301-336.

Monechi, S., and Thierstein, H.R., 1985. Late Cretaceous-Eocene nannofossil and magnetostratigraphic correlations near Gubbio, Italy. Mar. Micropaleontol. 9:419-440.

Moore, T.C., Jr., and Romine, K., 1981. In search of biostratigraphic resolution. In Warme, J.E., Douglas, R.G., and Winterer, E.L. (Eds.), The Deep Sea Drilling Project: a Decade of Progress. Spec. Publ.-Soc. Econ. Paleontol. Mineral., 32: 317-334.

Müller, C., 1979. Calcareous nannofossils from the North Atlantic (Leg 48). In Montadert, L., Roberts, D.G., et al., Init. Repts. DSDP, 48: Washington (U.S. Govt. Printing Office), 589-639.

, 1985. Biostratigraphic and paleoenvironmental interpretation of the Goban Spur region based on a study of calcareous nannoplankton. In de Graciansky, P.C., Poag, C.W., et al., Init. Repts. DSDP, 80: Washington (U.S. Govt. Printing Office), 573-599.

Okada, H., and Bukry, D., 1980. Supplementary modification and introduction of code numbers to the low-latitude coccolith biostratigraphic zonation (Bukry, 1973; 1975). Mar. Micropaleontol., 5:321-325.

Okada, H., and Thierstein, H.R., 1979. Calcareous nannoplankton-Leg 43, Deep Sea Drilling Project, In Tucholke, B.E., Vogt, P.R., et al., Init. Repts. DSDP, 43: Washington (U.S. Govt. Printing Office), 507-573.

Pak, D.K., and Miller, K.G., 1992. Paleocene to Eocene benthic foraminiferal isotopes and assemblages: implications for deepwater circulation. Paleoceanography, 7:405-422.

Perch-Nielsen, K., 1977. Albian to Pleistocene calcareous nannofossils from the western South Atlantic, DSDP Leg 39. In Supko, P.R., Perch-Nielsen, K., et al., Init. Repts. DSDP, 39: Washington (U.S. Govt. Printing Office), 699-823.

1985. Cenozoic calcareous nannofossils. In Bolli, H.M., Saunders, J.B., and Perch-Nielsen, K. (Eds.), Plankton Stratigraphy: Cambridge (Cambridge Univ. Press), 427-554.

Percival, S.F., 1983. Late Cretaceous to Pleistocene calcareous nannofossils from the South Atlantic, Deep Sea Drilling Project Leg 73. In Hsü, K.J., La Brecque, J.L. et al., Init. Repts. DSDP, 73: Washington (U.S. Govt. Printing Office), $391-424$.

Pisciotto, K.A., 1981. Distribution, thermal histories, isotopic compositions, and reflection characteristics of siliceous rocks recovered by the Deep Sea Drilling Project. In Warme, J.E., Douglas, R.G., and Winterer, E.L. (Eds.), The Deep Sea Drilling Project: A Decade of Progress. Spec. Publ.-Soc. Econ. Paleontol. Mineral., 32:129-148.

Pospichal, J.J., and Wise, S.W., Jr., 1990. Paleocene to middle Eocene calcareous nannofossils of ODP Sites 689 and 690, Maud Rise, Weddell Sea. In Barker, P.F., Kennett, J.P., et al., Proc. ODP. Sci. Results, 113: College Station, TX (Ocean Drilling Program), 613-638.

Prothero, D.R., and Berggren, W.A., 1992. Eocene-Oligocene Climatic and Biotic Evolution. Princeton, NJ (Princeton Univ. Press).

Proto Decima, F., Roth, P.H., and Todesco, L., 1975. Nannoplancton calcareo del Paleocene e dell'Eocene della Sezione di possagno. Schweiz Palaontol. Abh., 97:35-55.

Romein, A.J.T., 1979. Lineages in early Paleogene calcareous nannoplankton. Utrecht Micropaleontol. Bull., 22:1-231.

Roth, P.H., 1978. Cretaceous nannoplankton biostratigraphy and oceanography of the northwestern Atlantic Ocean. In Benson, W.E., Sheridan, R.E., et al., Init. Repts. DSDP, 44: Washington (U.S. Govt. Printing Office), 731-759.

Sager, W.W., Winterer, E.L., Firth, J.V., et al., 1993. Proc. ODP, Init. Repts., 143: College Station, TX (Ocean Drilling Program). 
Savin, S.M., 1977. The history of the Earth's surface temperature during the past 100 hundred million years. Annu. Rev. Earth. Planet Sci., 5:319-355.

Schlanger, S.O., and Douglas, R.G., 1974. The pelagic ooze-chalk-limestone transition and its implications for marine stratigraphy. In Hsü, K.J., and Jenkyns, H.C. (Eds.), Pelagic Sediments: On Land and Under the Sea. Spec. Publ. Int. Assoc. Sedimentol., 1:117-148.

Shackleton, N.J., 1986. Paleogene stable isotope events. Palaeogeogr., Palaeoclimatol., Palaeoecol., 57:91-102.

Shackleton, N.J., and Kennett, J.P., 1974. Paleotemperature history of the Cenozoic and the initiation of Antarctic glaciation: oxygen and carbon isotope analyses in DSDP Sites 277, 279, and 281. In Kennett, J.P., Houtz, R.E., et al., Init. Repts. DSDP, 29: Washington (U.S. Govt. Printing Office), 743-755.

Shaw, A.B., 1964. Time in Stratigraphy: New York (McGraw-Hill).

Siesser, W.G., and Bralower, T.J., 1992. Cenozoic calcareous nannofossil biostratigraphy on the Exmouth Plateau, Eastern Indian Ocean. In von Rad, U., Haq, B.U., et al., Proc. ODP, Sci. Results, 122: College Station, TX (Ocean Drilling Program), 601-631.

Stott, L.D., and Kennett, J.P., 1990. Antarctic Paleogene planktonic foraminifer biostratigraphy: ODP Leg 113, Sites 689 and 690. In Barker, P.F., Kennett, J.P., et al., Proc. ODP, Sci. Results, 113: College Station, TX (Ocean Drilling Program), 549-569.

Stott, L.D., and Zachos, J.C., 1991. Paleogene Paleoceanography Workshop Report, JOI-USSAC.

Thomas, E., 1990. Late Cretaceous through Neogene deep-sea benthic foraminifers (Maud Rise, Weddell Sea, Antarctica). In Barker, P.F., Kennett, J.P., et al., Proc. ODP, Sci. Results, 113: College Station, TX (Ocean Drilling Program), 571-594.

Tjalsma, R.C., and Lohmann, G.P., 1983. Paleocene-Eocene bathyal and abyssal benthic foraminifera from the Atlantic Ocean. Micropaleontology: Spec. Publ., 4.

van Heck, S.E., and Prins, B., 1987. A refined nannoplankton zonation for the Danian of the Central North Sea. Abh. Geol. Bundensanst. (Austria), 39:285-303.

Wei, W., 1992. Paleogene chronology of southern Ocean Drill Holes: an update. The Antarctic Paleoenvironment: A Perspective on Global Change. Antarct. Res. Ser., 56:75-96.

1993. Clarification of Coccolithus crassus Bramlette and Sullivan, an index fossil of Coccolithophoridae. J. Paleontol., 67:135-138.

Wei, W., and Pospichal, J.J., 1991. Danian calcareous nannofossil succession at Site 738 in the southern Indian Ocean. In Barron, J., Larsen, B., et al., Proc. ODP, Sci. Results, 119: College Station, TX (Ocean Drilling Program), 495-512.

Wei, W., and Thierstein, H.R., 1991. Upper Cretaceous and Cenozoic calcareous nannofossils of the Kerguelen Plateau (southern Indian Ocean) and Prydz Bay (East Antarctica). In Barron, J., Larsen, B., et al., Proc. ODP, Sci. Results, 119: College Station, TX (Ocean Drilling Program), 467-494.

Wei, W., and Wise, S.W., Jr., 1989. Paleogene calcareous nannofossil magnetobiochronology: results from South Atlantic DSDP Site 516. Mar: Micropaleontol., 14:119-152.

1990. Middle Eocene to Pleistocene calcareous nannofossils recovered by Ocean Drilling Program Leg 113 in the Weddell Sea. In Barker, P.F., Kennett, J.P., et al., Proc. ODP, Sci. Results, 113: College Station, TX (Ocean Drilling Program), 639-666.

, 1992. Eocene-Oligocene calcareous nannofossil magnetobiochronology of the Southern Ocean. Newsl. Stratigr., 26:119-132.

Wise, S.W., Jr., 1983. Mesozoic and Cenozoic calcareous nannofossils recovered by Deep Sea Drilling Project Leg 71 in the Falkland Plateau region, Southwest Atlantic Ocean. In Ludwig, W.J., Krasheninnikov, V.A., et al., Init. Repts. DSDP, 71 (Pt. 2): Washington (U.S. Govt. Printing Office), 481-550.

Wise, S.W., Jr., and Wind, F.H., 1977. Mesozoic and Cenozoic calcareous nannofossils recovered by DSDP Leg 36 drilling on the Falkland Plateau, Southwest Atlantic sector of the Southern Ocean. In Barker, P.F., Dalziel, I.W.D., et al., Init. Repts. DSDP, 36: Washington (U.S. Govt. Printing Office), 269-492.

Zachos, J.C., Lohmann, K.C., Walker, J.C.G., and Wise, S.W., Jr., 1993. Abrupt climate change and transient climates during the Paleogene: a marine perspective. J. Geol., 101:191-213.

\footnotetext{
Date of initial receipt: 1 December 1993

Date of acceptance: 24 May 1994

Ms 143SR-204
}

\section{APPENDIX}

\section{Calcareous Nannofossil Taxonomy}

Birkelundia staurion (Bramlette and Sullivan, 1961) Perch-Nielsen, 1971 (Pl. 1, Figs. 13-14)

Braarudosphaera bigelowii (Gran and Braarud, 1935) Deflandre, 1954 Bramletteius serraculoides Gartner, 1969

(Pl. 3, Figs. 11-12)

Remarks. We have observed specimens resembling $B$. serraculoides at the top of Cores 143-865B-8H and 143-865C-8H. The holotype of this species, a side view of a coccolith that possesses a characteristic flange of low birefringence, has an irregular three-faceted face at the end away from the coccolith. These early specimens differ from the holotype specimen in having a one- or two-faceted face and are not included in the definition of this species.

Calcidiscus protoannulus (Gartner, 1971) Loeblich and Tappan, 1978 (Pl. 4, Figs. 25-28)

Remarks. See comments for Coronocyclus nitiscens.

\section{Campylosphaera}

Remarks. The diagnostic shield structure of this genus can be distinguished even when the delicate cross has been removed by etching. We have extended the ranges of both species downward based on observations of cross-less specimens. Accurate biostratigraphic use of these species, however, will only be achieved once differential diagnoses have been established through detailed biometric study. We have seen numerous irregular specimens with one flat and one curved edge (PI. 13, Fig. 2). These have been left unclassified.

Campylosphaera dela (Bramlette and Sullivan, 1961) Hay and Mohler, 1967 (Pl. 1, Figs. 27-28; Pl. 13, Figs. 3-4)

Remarks. We observed specimens of this species below its previously reported range in Zones CP8 or NP9 (e.g., Berggren and Aubry, in press) (Tables 1-3). The earliest specimens are small (long axis, $\sim 4-5 \mu \mathrm{m}$ ) and usually have the delicate cross etched out. These are distinguished entirely from their shape (somewhat squared ends) and diagnostic shield structure. The size of $C$. dela increases gradually upsection.

Campylosphaera eodela Bukry and Percival, 1971

(Pl. 1, Figs. 21-26; Pl. 13, Fig. 1)

Remarks. We observed specimens of this species far below its previously reported range in Zones CP6 or NP7 (Tables 1-3). The earliest specimens are very small (long axis, $\sim 3-4 \mu \mathrm{m}$ ) (Pl. 1, Figs. 21-22) and usually have the delicate cross etched out. These are distinguished entirely from their elongated shape and diagnostic shield structure. $C$. eodela grades with $C$. dela throughout their overlapping range. The LO of this species is a diagnostic event in the lower Eocene. The evolution of this species is illustrated in Plate 1, Figures 21-26.

\section{Chiasmolithus}

Remarks. This genus is difficult to subdivide in the lower Paleocene part of the section in Holes $865 \mathrm{~B}$ and $865 \mathrm{C}$ because central areas are small and commonly overgrown (see comments for C. bidens and C. danicus). Several forms of Chiasmolithus that occur near the Paleocene/Eocene boundary at Site 865 cannot be assigned to an individual species.

Chiasmolithus bidens (Bramlette and Sullivan, 1961) Hay and Mohler, 1967 (Pl. 2, Figs. 11-12)

Remarks. It is difficult to differentiate this species from large $C$. danicus in poorly preserved material. However, we have had little difficulty in distinguishing this species from $C$. solitus in the uppermost Paleocene and lower Eocene; the latter is larger $(>12 \mu \mathrm{m})$. C. bidens is mostly $\sim 6-8 \mu \mathrm{m}$ and thicker (higher birefringence); it also has a larger angle between bars.

Chiasmolithus californicus (Sullivan, 1964) Hay and Mohler, 1967 (PI. 2, Figs. 15 and 24)

Remarks. This is a large ( $>\sim 10 \mu \mathrm{m})$ version of $C$. consuetus, which usually possesses a highly birefringent (second-order yellow) shield. The shield of $C$. consuetus is first-order gray in cross-polarized light. 
Chiasmolithus consuetus (Bramlette and Sullivan, 1961)

Hay and Mohler, 1967

(Pl. 2, Figs. 3-10)

Chiasmolithus danicus (Brotzen, 1959) Hay and Mohler, 1967 (Pl. 2, Figs. 1-2)

Chiasmolithus eograndis Perch-Nielsen, 1971

(PI. 2, Figs. 22-23)

Remarks. This species evolves from $C$. solitus and gives rise to $C$. grandis (Gartner, 1969). It differs from C. grandis both in the lack of teeth and by its less regular cross. C. solitus has a lower angle between the long bar of the cross and the two offset bars.

Chiasmolithus expansus (Bramlette and Sullivan, 1961) Gartner, 1970 (Pl. 3, Figs. 5-6)

Chiasmolithus gigas (Bramlette and Sullivan, 1961) Radomski, 1968 (Pl. 3, Figs. 1-2)

Remarks. We observed forms of $C$. gigas in which the cross was much reduced in size. These occurred in the lower and upper parts of the range of this species. Commonly, in the material investigated, the cross has been completely etched out of the coccolith, leaving a morphology that closely resembles Coccolithus pelagicus. Thus, establishing the precise range of this form is extremely difficult, especially at the top of the range where large specimens of $C$. pelagicus are more common.

Chiasmolithus grandis (Bramlette and Riedel, 1954) Radomski, 1968 (Pl. 3, Figs. 3-4)

Chiasmolithus medius Perch-Nielsen, 1971

(PI. 2, Figs. 18-21)

Remarks. We noticed that this species often has an extension to the cross at its contact with the inner part of the shield (or foot) (Pl. 2, Figs. 18-21). In the earliest specimens, this foot is barely visible, but it increases in length and width gradually upsection.

\section{Chiasmolithus mutatus Perch-Nielsen, 1971}

Chiasmolithus nitidus Perch-Nielsen, 1971

$$
\text { (Pl. 3, Figs. 13-18) }
$$

Remarks. This species possesses a distinctive offset cross, often with footed ends. It can be very small $(\sim 3-4 \mu \mathrm{m})$.

\section{Chiasmolithus oamaruensis (Deflandre, 1954) \\ Hay, Mohler, and Wade, 1966}

(PI. 3, Figs. 7-8)

Chiasmolithus solitus Bramlette and Sullivan, 1961

(PI. 2, Figs. 13-14 and 16-17)

Remarks. See comments for $C$. bidens. This species has a patchy distribution in the lowest part of its range (upper Paleocene). The size of this species reaches a peak in the early Eocene, where specimens with long axes of $15 \mu \mathrm{m}$ are common. Middle and late Eocene age specimens are closer to $10 \mu \mathrm{m}$ in length.

Chiasmolithus titus Gartner, 1970

Coccolithus crassus Bramlette and Sullivan, 1961

(PI. 4, Figs. 19-20)

Remarks. The criteria described by Wei (1993), particularly the birefringent distal shield, are useful for distinguishing this form. However, we saw many specimens that were transitional with $C$. pelagicus, particularly in the lower part of the range. Specimens of $C$. crassus tend to be smaller $(6-9 \mu \mathrm{m})$ than elsewhere, and the distal shield often is partly etched, exposing the less birefringent proximal shield. This species was not as common in material from Site 865 as has been reported from other locations.

Coccolithus pelagicus (Wallich, 1877) Schiller, 1930

(PI. 12, Figs. 20-21; Pl. 13, Figs. 5-6)

Remarks. We illustrate specimens with a well-defined, albeit small cross in the central area (Pl. 13, Figs. 5-6).

Coronocyclus nitescens (Kamptner, 1963) Bramlette and Wilcoxon, 1967 (Pl. 4, Figs. 21-24)

Remarks. This species has a thicker, higher inner cycle than Calcidiscus protoannulus. The latter is larger; however, intermediate forms have been observed, suggesting that these two species are related. Detailed ultrastructural work clearly is required to verify this suggestion. In the lower part of the section, it is difficult to distinguish this species from Ericsonia robusta; we use the greater brightness of the inner shield cycle.

Cruciplacolithus asymmetricus van Heck and Prins, 1987

(PI. 1, Figs. 9-10)

Remarks. A form similar to that described by van Heck and Prins (1987) in Danian sediments from the North Sea has been observed in upper Paleocene and lowermost Eocene samples from Site 865. The specimens observed here are somewhat larger $(\sim 12-15 \mu \mathrm{m})$ than those described, but possess a similar symmetrical cross at a slight $\left(5^{\circ}-10^{\circ}\right)$ angle to the major axis of the ellipse. Some very small specimens $(\sim 6 \mu \mathrm{m})$ have been observed in the lower Eocene, but they are not included in this taxon. This species appears to evolve into an (unclassified?) chiasmolith with a robust cross diagonal to the long axis. Observations in lower Paleocene sediments should reveal the relationship of the forms described by van Heck and Prins (1987) to those described here.

Cruciplacolithus cribellum (Bramlette and Sullivan, 1961) Romein, 1979 (PI. 1, Figs. 15-16)

Remarks. Differentiating this species from $C$. vanheckii proved to be somewhat difficult in material from Site 865 . Although some overlap occurs, C. cribellum has a wider rim and a less elongated shape than $C$. vanheckii. Both of these taxa are very rare in Site 865 material; however, their ranges appear to overlap, which strengthens the suggestion that they are related.

\section{Cruciplacolithus frequens (Perch-Nielsen, 1977) Romein, 1979}

(PI. 1, Figs. 7-8)

Remarks. This species can be difficult to distinguish from C. tenuis if specimens are not lying perfectly flat. Shape is the easiest criterion to use: $C$. frequens is almost round, $C$. tenuis has a much higher ellipticity. Viewed parallel to the long axis, the cross in $C$. frequens can appear to be aligned with the long axis, when in fact it is not. A few specimens were observed in the lower Eocene above its extinction level, but these have much smaller windows and less obvious feet. Thus, these forms have not been included in C. frequens.

$$
\text { Cruciplacolithus latipons Romein, } 1979
$$

Cruciplacolithus primus Perch-Nielsen, 1977

Remarks. We have not differentiated $C$. primus from the larger $C$. intermedius (van Heck and Prins, 1987) as we saw very few large, simple cruciplacoliths (see discussion under Cruciplacolithus sp.).

Cruciplacolithus subrotundus Perch-Nielsen, 1969

Cruciplacolithus tenuis (Stradner, 1961) Hay and Mohler in Hay et al., 1967

$$
\text { (PI. 1, Figs. 1-6) }
$$

Remarks. In the last few meters of its range, specimens of $C$. tenuis become small $(\sim 5-6 \mu \mathrm{m}$ long) and have a very small cross (e.g., PI. 1, Figs. 5-6).

\section{Cruciplacolithus vanheckii Perch-Nielsen, 1984}

$$
\text { (PI. 1, Figs. 17-20) }
$$

Remarks. See comments for $C$. cribellum. The earliest specimens of $C$. vanheckii are somewhat difficult to differentiate from $C$. cribellum, but there is rapid upward evolution toward the more distinctive narrow and elongated shape. We noticed that in the upper part of the range of this species, a trend toward broader specimens occurs, so that in uppermost samples, $C$. vanheckii starts to resemble $C$. cribellum again. Specimens of $C$. vanheckii tend to be smaller than C. cribellum (not larger, as found by Perch-Nielsen, 1984). C. vanheckii is differentiated from Clausiococcus fenestratus by the structure of its shield and the outer part of the central area.

\section{Cruciplacolithus sp.}

(PI. 1, Figs. 11-12)

Remarks. A host of different cruciplacoliths will require further observation. Some of these were identified by van Heck and Prins (1987). We isolated one form under the term Cruciplacolithus sp. This species appears to have evolved from $C$. primus by slight $\left(<10^{\circ}\right)$ tilting of the cross with respect to the long axis of the ellipse. In the lowermost Eocene, the cross begins to rotate closer to the diagonal of the ellipse. This taxon differs from $C$. tenuis in its lack of feet and from C. edwardsii by a lower angle of tilting of the cross and lack of offset between the two axes of the cross. 


\section{Cyclicargolithus spp. (Roth and Hay in Hay et al., 1967) Bukry, 1971}

(Pl. 9, Figs. 27-28; Pl. 13, Fig. 8)

Remarks. A variety of forms are included in this taxon, which arises in the early Eocene and dominates assemblages in the middle Eocene. Most of these forms are fairly small ( $5-10 \mu \mathrm{m}$ in diameter). The taxonomy of this genus in the early part of its range is not at all clear and requires detailed SEM observation. Comparison of the ranges of individual species from different sources, therefore, is unreliable. For this reason, we have not differentiated among species. In this genus, we include several different forms: round specimens with a small central opening (e.g., Pl. 13, Fig. 8) and round specimens with a large central opening. Other forms are elliptical but lack a clear tube in the central area; these may be transitional between $C y c l i c a r$ golithus and Reticulofenestra. All specimens with a tube (e.g., Pl. 13, Figs. 9-10), most of which are elliptical in shape, are included in Reticulofenestra.

\section{Dictyococcites bisectus (Hay, Mohler, and Wade, 1966)} Bukry and Percival, 1971

\section{(PI. 9, Figs. 37-38)}

Remarks. This species has been differentiated from $D$. scrippsae by its larger size and more circular outline. Although there is a dearth of exact size information on the difference between these two taxa in the literature, 10 to 11 $\mu \mathrm{m}$ seems to be a generally accepted lower limit for the size difference between these two species, and this limit was used here.

\section{Dictyococcites scrippsae Bukry and Percival, 1971}

$$
\text { (Pl. 9, Figs. 35-36) }
$$

Remarks. See comments for D. bisectus.

\section{Discoaster}

Remarks. This is the most difficult genus to work with in the section investigated. Problems arise from the pervasive overgrowth, which radically changes the shape of specimens. In addition, there are a plethora of forms that are gradational between existing species or that have not been described. We used strict species concepts similar to those compiled by Aubry (1984). Other unclassifiable forms have been grouped under Discoaster spp.

\section{Discoaster barbadiensis Tan, 1927}

(Pl. 5, Fig. 15)

Remarks. It is difficult given the overgrown state of most discoasters to differentiate $D$. barbadiensis from the $D$. nobilis plexus (see below). We have seen specimens in the lowest Eocene that have the correct number of rays, which are joined for approximately two-thirds of their length. The joins between the rays, however, tend to be slightly curved. Other specimens are thicker than D. barbadiensis or have shorter unjoined segments. Because of the multitude of forms, the FO of $D$. barbadiensis is a difficult event to determine. We have observed gradation between $D$. barbadiensis and $D$. multiradiatus in Zone NP11. We distinguish the FO of D. barbadiensis by observing the gradual reduction in the number of rays and the lengthening of the unjoined parts of the rays of $D$. multiradiatus.

\section{Discoaster binodosus Martini, 1958 \\ Discoaster boulangeri Lezaud (1968)} (PI. 5, Fig. 18)

Discoaster deflandrei Bramlette and Riedel, 1954

$$
\text { (Pl. 6, Fig. 4) }
$$

Discoaster diastypus Bramlette and Sullivan, 1961 (Pl. 5, Fig. 14)

Remarks. This stratigraphically important species is exceptionally rare in samples from the lower Eocene. Three questionable specimens were observed in three different samples from Hole 865C. In the lowermost (Sample 143-865C$12 \mathrm{H}-1,60-62 \mathrm{~cm})$, a single specimen has 17 elements that appear to be straight. Specimens from Core $143-865 \mathrm{C}-10 \mathrm{H}$ are similar, but possess a smaller number of rays (14 and 15). Because true $D$. diastypus should be curved sinistrally and have less than 16 rays (e.g., Aubry, 1984), we have called these specimens $D$. cf. $D$. diastypus. In addition, true diagnosis of this species requires observation of individual specimens from both sides in a mobile mount.

Discoaster elegans Bramlette and Sullivan, 1961 (Pl. 5, Fig. 10)

Discoaster falcatus Bramlette and Sullivan, 1961
Remarks. See comments for D. lodoensis.

\section{Discoaster kuepperi Stradner, 1959}

Remarks. Specimens are very much overgrown and can be mistaken easily for Sphenolithus moriformis, but they are thicker and thus more birefringent (second-order red). In a bright field, the Discoaster structure can be observed clearly.

\section{Discoaster lenticularis Bramlette and Sullivan, 1961}

$$
\text { (Pl. 5, Figs. 12-13) }
$$

Remarks. This species is considerably smaller than D. multiradiatus, and the rays curve characteristically toward their ends.

\section{Discoaster lodoensis Bramlette and Riedel, 1954 \\ (PI. 6, Figs. 1-3; PI. 14, Fig. 8)}

Remarks. This species varied in preservation. Some forms have excellent preservation; others are overgrown and show only subtle evidence of bending of the tips of the rays (e.g., Pl. 14, Fig. 8). In addition to the ray tips, we used the large size (usually $15-20 \mu \mathrm{m}$ ) to identify this species. Assemblages near the ends of the range of this species have large numbers of forms that have seven rays (earliest) and five and seven rays (latest). A few similar specimens with eight rays (D. falcatus) were observed in the uppermost Paleocene and lowermost Eocene. The possibility of confusion with $D$. strictus exists in the overgrown forms, in which the ray tips appear straight (see comments for $D$. strictus and D. sublodoensis).

\section{Discoaster mohleri Bukry and Percival, 1971}

$$
\text { (Pl. 5, Figs. 2-4; Pl. 14, Fig. 10) }
$$

Remarks. We noted that in the first few meters of the range of $D$. mohleri at Site 865, specimens had a somewhat simpler structure than typical specimens of this species; they are very thin (low birefringence) and possess no overlapping of rays. It is possible, therefore, that these forms may represent a gradational form with $D$. bramlettei. We observed (but excluded from this species) a few specimens in the lowermost Eocene that have slightly extended rays. Specimens are small ( $\sim-6 \mu \mathrm{m}$ in diameter) in the lowermost and uppermost few meters of the range of this species.

\section{Discoaster multiradiatus Bramlette and Riedel, 1954 \\ (Pl. 5, Figs. 6-8 and 11)}

Remarks. As with $D$. mohleri, this species may also grade with $D$. bramlettei. See comments on $D$. lenticularis.

\section{Discoaster nobilis Martini, 1961}

(PI. 5, Figs. 5 and 9)

Remarks. This biostratigraphically significant species was difficult to identify in material from Site 865 . The rays of true $D$. nobilis should be slightly curved and have ribs on one side (e.g., Aubry, 1984). At Site 865, overgrowth has masked features such as ribs. Typical specimens of this species were observed only in Zones CP8 and CP9. In the early part of the range of this species (Zone CP7), etching has commonly removed the ends of the rays. Where the rays can be observed, it is simple to differentiate $D$. nobilis from $D$, mohleri by its extended rays. In other cases, we identified $D$. nobilis by its characteristically high relief. In the upper part of the range of this species, we combined a variety of forms under this name, forms that other researchers might include in D. elegans or D. floridus. Once again, overgrowth prevented detailed classification of this plexus of species.

\section{Discoaster nodifer (Bramlette and Riedel, 1954) Bukry, 1973} (Pl. 6, Fig. 10)

Remarks. This species arises in the middle Eocene. Small forms 7-8 $\mu \mathrm{m}$ in diameter were observed in the early part of its range; these were included in the informal taxon D. "prenodifer." A gradual increase in size occurs in the upper part of the middle Eocene. As compiled by Aubry (1984), only forms larger than $13 \mu \mathrm{m}$ have been included in $D$. nodifer sensu stricto. Specimens are too overgrown to observe nodes on the rays.

\section{Discoaster okadai Bukry, 1981 \\ Discoaster "prenodifer" \\ (Pl. 6, Fig. 9)}

Remarks. Informal name used here. See comments for $D$. nodifer. 


\section{Discoaster "presaipanensis"}

Remarks. Informal name used here. See comments for $D$. saipanensis.

\section{Discoaster "pretanii"}

(Pl. 6, Fig. 8)

Remarks. Informal name used here. See comments for $D$. tanii.

\section{Discoaster saipanensis Bramlette and Riedel, 1954}

(Pl. 6, Fig. 15)

Remarks. This species can also be difficult to recognize when overgrown. We restricted this species to forms with fewer than nine rays; forms informally called "presaipanensis" have the same shape but 10 or more rays.

\section{Discoaster salisburgensis Stradner, 196 \\ Discoaster strictus Stradner, 1961}

(Pl. 6, Fig. 7)

Remarks. Well-preserved forms of this species have a characteristic outline, formed at the connection of rays. This feature is completely overgrown in all of the specimens observed here. See comments for $D$. lodoensis.

Discoaster sublodoensis Bramlette and Sullivan, 1961

(PI. 6, Figs. 5-6; Pl. 14, Fig. 9)

Remarks. This species can be difficult to differentiate from $D$. lodoensis when overgrown, as an array of intermediate forms exist. We have a strict concept of this species and restricted it to small forms having five rays that appear straight when overgrown (e.g., Pl. 14, Fig. 9), not curved as in D. lodoensis (e.g., PI. 14, Fig. 8). Specimens classified as D. sublodoensis tend to be smaller than $10 \mu \mathrm{m}$. In the upper part of the range of $D$. lodoensis, assemblages are dominated by small, uncurved six-rayed forms, which are directly intermediate between this species and $D$. sublodoensis. Other workers might include these forms in D. sublodoensis. The FO of this species depends heavily on definition and may vary by several meters, according to the concepts used.

\section{Discoaster tanii Bramlette and Riedel, 1954}

(PI. 6, Fig. 11)

Remarks. As in D. nodifer, a gradual increase in size is seen in the upper part of middle Eocene. Small forms $(7-8 \mu \mathrm{m})$ have been observed in the early part of the range (these are included in $D$. "pretanii"): however, only forms larger than $13 \mu \mathrm{m}$ were included in D. tanii sensu stricto. All of the forms are too overgrown to observe nodes on the rays.

\section{Discoaster spp. \\ (Pl. 5, Fig. 1; Pl. 6, Fig. 16) \\ Ellipsolithus bollii Perch-Nielsen, 1977}

(PI. 8, Figs. 3-6)

Remarks. See comments for E. distichus.

$$
\begin{aligned}
& \text { Ellipsolithus distichus (Bramlette and Sullivan, 1961) } \\
& \text { Sullivan, 1964 } \\
& \text { (PI. 8, Figs. 7-12) }
\end{aligned}
$$

Remarks. We noticed that the position of the row of openings in this species varied significantly. In some specimens, these were located close to the center, but in other cases they were positioned closer to the rim. We distinguished these latter forms from $E$. bollii by the size of the openings, which were significantly larger than in $E$. bollii. We observed a few specimens of $E$. distichus in the lower Eocene above their reported range. These specimens have large openings, which are located close to the center and thus are also transitional between $E$. bollii and $E$. distichus. It is likely that this form bridges the gap between the currently separated ranges of $E$. distichus and $E$. lajollaensis (e.g., Perch-Nielsen, 1985).

\section{Ellipsolithus lajollaensis Bukry and Percival, 1971} (Pl. 8, Figs. 19-20; Pl. 14, Fig. 4)

Remarks. See comments on Ellipsolithus sp.

$$
\begin{aligned}
& \text { Ellipsolithus macellus (Bramlette and Sullivan, 1961) } \\
& \text { Sullivan, 1964 } \\
& \text { (Pl. 8, Figs. 1-2) }
\end{aligned}
$$

Ellipsolithus sp.

(Pl. 8, Figs. 21-24; Pl. 14, Fig. 5)

Remarks. This form has an open central area; however, a parallel-sided ellipsolith rim was observed in the uppermost Paleocene and lower Eocene. Therefore, it is possible that this form was produced by etching of $E$. lajollaensis and should be investigated in more detail.

\section{Ericsonia cava (Hay and Mohler, 1967) Perch-Nielsen, 1969 \\ Ericsonia formosa (Kamptner, 1963) Haq, 1971$$
\text { (PI. 4, Figs. 5-6) }
$$

Remarks. Previously, rather arbitrary criteria have been used to differentiate this species from E. subpertusa. Both the size of the central opening and the sharpness of the extinction cross in cross-polarized light were used. The size of the central opening of $E$. subpertusa increases fairly rapidly in the lower Eocene; at approximately the same level, the extinction cross becomes more distinct. The latter feature, however, can be very subjective. Therefore, we have used an arbitrary limit of relative diameter of the central opening to distinguish these two taxa: in E. formosa, the width of the opening is greater than $25 \%$ of the coccolith width; in E. subpertusa, the width is less than $25 \%$. From a biostratigraphic viewpoint, it is fortunate that the ranges of $E$. formosa and $E$. robusta do not overlap. Clearly, morphometric work will be required for all of these taxa.

\section{Ericsonia insolita Perch-Nielsen, 1971}

(Pl. 3, Figs. 9-10; Pl. 13, Fig. 7)

Remarks. This species is quite common in the middle and upper Eocene. It may grade into $C$. pelagicus (see Pl. 13, Figs. 5-7), and we would prefer to include it in Coccolithus because of its shape.

\section{Ericsonia obruta Perch-Nielsen, 197}

$$
\text { (PI. 4, Figs. 13-14) }
$$

Ericsonia robusta (Bramlette and Sullivan, 1961) Perch-Nielsen, 1977

$$
\text { (PI. 4, Figs. 7-8) }
$$

Remarks. We differentiate $E$. robusta from the large form referred to as $E$. cf. E. robusta by Perch-Nielsen (1985) (Pl. 4, Figs. 9-12). The latter is larger $(>10 \mu \mathrm{m})$ and brighter in cross-polarized light (completely first-order white-yellow); it also has a relatively wider central area. See comments on $C$. nitiscens.

$$
\begin{array}{r}
\text { Ericsonia subdisticha (Roth and Hay in Hay et al., 1967) } \\
\text { Roth in Baumann and Roth, } 1969 \\
\text { (Pl. 4, Figs. 15-16) } \\
\text { Ericsonia subpertusa Hay and Mohler, } 1967 \\
\text { (Pl. 4, Figs. 1-4) }
\end{array}
$$

\section{Fasciculithus}

Remarks. We found the taxonomy and biostratigraphy of this genus difficult to apply, with the exception of $F$. pileatus, F. ulii, and $F$. tympaniformis. There appears to be a significant amount of intergradation between taxa, and only end-members can be classified confidently. We commonly observed $F$. pileatus, $F$. ulii, $F$. tympaniformis, $F$. involutus, $F$. schaubii, $F$. lilianae, and $F$. aubertae. Our ranges for $F$. involutus and $F$. lilianae may be slightly longer than the widely accepted ones of Romein (1979), as our species concepts are slightly different.

Fasciculithus alanii Perch-Nielsen, 1971

Fasciculithus aubertae Haq and Aubry, 1981

$$
\text { (Pl. 7, Figs. 11-12) }
$$

Remarks. The type of this species is rectangular, which is the feature that we used to distinguish this taxon; however, the specimens observed here can be significantly wider than those described elsewhere. This species is often less than $3 \mu \mathrm{m}$ in width in the uppermost Paleocene.

Fasciculithus billiii Perch-Nielsen, 1971

Fasciculithus bobbii Perch-Nielsen, 1971

Fasciculithus involutus Bramlette and Sullivan, 1961

$$
\text { (Pl. 7, Fig. 7) }
$$

Remarks. We differentiate this taxon from $F$. tympaniformis by its almost squared shape. The cone of $F$. tympaniformis slopes distinctly. 


\section{Fasciculithus lillianae Perch-Nielsen, 1971}

(PI. 7, Figs. 8-9)

Remarks. We include an array of forms in this species. In all of them, the bottom margin slopes at a high angle.

\section{Fasciculithus pileatus Bukry, 1973}

(PI. 7, Figs. 1-4)

Fasciculithus richardii Perch-Nielsen, 1971

Fasciculithus schaubii Hay and Mohler, 1967 (Pl. 7, Fig. 10)

Fasciculithus stonehengei $\mathrm{Haq}$ and Aubry, 1981

Fasciculithus thomasii Perch-Nielsen, 1971

Fasciculithus tympaniformis Hay and Mohler in Hay et al., 1967 (PI. 7, Figs. 5-6)

Remarks. This species can be less than $3 \mu \mathrm{m}$ in width in the uppermost Paleocene. See comments for $F$. involutus.

Fasciculithus ulii Perch-Nielsen, 1971

\section{Helicosphaera}

Remarks. More than half of the specimens of Helicosphaera observed in material from Site 865 have completely etched central areas. This can make differentiation of species almost impossible. Where central areas were present, however, the following species were differentiated.

Helicosphaera dinesii Perch-Nielsen, 1971

Helicosphaera heezenii Bukry, 1971

Helicosphaera lophota Bramlette and Sullivan, 1961

(Pl. 8, Figs. 15-16)

Helicosphaera papillata Bukry and Bramlette, 1969

Helicosphaera reticulata Bramlette and Wilcoxon, 1967

(Pl. 8, Fig. 17-18)

Helicosphaera seminulum Bramlette and Sullivan, 1961

(PI. 8, Figs. 13-14)

Heliolithus cantabriae Perch-Nielsen, 1971

Remarks. It is difficult to distinguish this species from a plan view of a Fasciculithus. This is dependent upon observing an outer edge with lower birefringence and a bright center that is well differentiated into "rays."

Heliolithus(?) floris Haq and Aubry (1981)

(Pl. 6, Figs. 12-13 and 19-20)

Heliolithus kleinpellii Sullivan, 1964

(PI. 6, Figs. 14 and 21)

Heliolithus riedelii Bramlette and Sullivan, 1961

(Pl. 6, Figs. 17-18)

Lophodolithus mochloporus Deflandre in Deflandre and Fert, 1954 (Pl. 10, Figs. 15-16)

Lophodolithus nascens Bramlette and Sullivan, 1961 (Pl, 10, Figs. 11-14)

Lophodolithus rotundus Bukry and Percival, 1971 (Pl. 10, Figs. 17-18)

Markalius inversus (Deflandre in Deflandre and Fert, 1954) Bramlette and Martini, 1964

(Pl. 4, Figs. 17-18)

\section{Micula sp.}

Nannotetrina

Remarks. A variety of forms belonging to this genus were observed. The shape of many specimens of Nannotetrina has been affected by overgrowth. A variety of cross-shaped and blocky forms were seen. Cross-shaped forms have both pointed and squared to rounded tips. Opposite rays can be aligned as in a simple cross, or slightly offset, in the fashion of the Cretaceous genus Micula. In most samples, however, we observed forms having a variable preservational state so that blocky forms have not been classified separately. Previous researchers (e.g., Romein, 1979; Aubry, 1983) have combined several species of Nannotetrina that have long arms and a small basket close to the junction and have included these taxa in $N$. fulgens. These authors separate this species from a smaller, earlier form having a large basket, covering one entire side, called $N$. cristata. This species was not observed in our samples. We differentiated two taxa.

\section{Nannotetrina fulgens (Stradner, 1960) Achuthan and Stradner, 1969} (PI. 12, Figs. 6-7)

Remarks. This species has very pointed rays and grows rapidly from about $10 \mu \mathrm{m}$ close to its FO to more than $20 \mu \mathrm{m}$ several meters above its FO. When overgrown, the rays tend to be slightly offset from one another.

$$
\begin{aligned}
& \text { Nannotetrina sp. } \\
& \text { (PI. 12, Figs. } 5 \text { and } 8 \text { ) }
\end{aligned}
$$

Remarks. This form has pointed but usually squared or slightly rounded rays and tends to be more overgrown than $N$. fulgens so that the basket is invisible. There is no offset of opposite rays; it is between 5 and $10 \mu \mathrm{m}$ wide. This form evolves in Zone NP12 (CP11), just below the highest occurrence of T. orthostylus.

Neochiastozygus cearae Perch-Nielsen, 1977

Neochiastozygus chiastus (Bramlette and Sullivan, 1961) Perch-Nielsen, 1971

Neochiastozygus concinnus (Martini, 1961)

Perch-Nielsen, 197

(PI. 11, Figs. 1-2)

Neochiastozygus distentus (Bramlette and Sullivan, 1961) Perch-Nielsen, 1971 (Pl. 11, Fig. 3-6)

Neochiastozygus junctus (Bramlette and Sullivan, 1961) Perch-Nielsen, 1971 (Pl. 11, Figs. 13-18)

Remarks. We had some difficulty distinguishing this species from $N$ perfectus. In $N$. junctus, we included specimens with virtually no opening between nearly parallel bars (Pl. 11, Figs. 13-18). Specimens in which the opening is at least as wide as a single cross-bar are included in $N$. perfectus (e.g., Pl. 11, Figs. 9-12).

\section{Neochiastozygus modestus Perch-Nielsen, 1971}

(Pl. 11, Figs. 7-8

Remarks. We have classified an array of simple cross-shaped forms of Neochiastozygus under this taxon.

\section{Neochiastozygus perfectus Perch-Nielsen, 1971}

(PI. 11, Figs. 9-12)

Remarks. See comments for $N$. junctus.

Neochiastozygus primitivus Perch-Nielsen, 1981

Neochiastozygus saepes Perch-Nielsen, 1971

Neococcolithes dubius (Deflandre, 1954) Black, 1967

(Pl. 11, Figs. 21-22)

Neococcolithes protenus (Bramlette and Sullivan, 1961) Black, 1967

(Pl. 11, Figs. 19-20)

Neocrepidolithus biskayae Perch-Nielsen, 1981

Neocrepidolithus bukryi Perch-Nielsen, 1981

(Pl. 10, Figs. 19-20 and 25)

Neocrepidolithus sp.

(PI. 10, Figs. 21-24)

Remarks. This distinctive taxon, which has not been formally subdivided, is a useful secondary marker. The form of this taxon is variable, but it seems to become more open through time. A more detailed taxonomy clearly is required.

\section{Pedinocyclus larvalis (Bukry and Bramlette, 1969)}

Loeblich and Tappan, 1973

(Pl. 4, Figs. 31-34; Pl. 14, Fig. 7)

Remarks. This round species may evolve from a form with a very similar shield that is elliptical in shape. We have called this form P. "prelarvalis" informally. There is an apparent evolution from a large central opening (e.g., Pl. 4, Figs. 31-32) toward closure of the opening (e.g., Pl. 4, Figs. 33-34). 
Pedinocyclus "prelarvalis"

(Pl. 4, Figs. 29-30; Pl. 14, Fig. 6)

Remarks. An informal taxon used here. See comments for $P$. larvalis.

Placozygus sigmoides (Bramlette and Sullivan, 1961) Romein, 1979 (Pl. 10, Figs. 1-2)

Pontosphaera scissura (Perch-Nielsen, 1971) Romein, 1979

Pontosphaera spp.

Remarks. As a result of pervasive etching of the central areas, most species of this genus could not be consistently differentiated.

Prinsius bisulcus (Stradner, 1963) Hay and Mohler, 1967

(PI. 9, Figs. 3-6)

Prinsius dimorphosus (Perch-Nielsen, 1969) Perch-Nielsen, 1977

Prinsius martinii (Perch-Nielsen, 1969) Haq, 1971

(Pl. 9, Figs. 1-2)

Reticulofenestra

Remarks. This genus is characterized by variable species concepts. For this reason, the application of many taxa in biostratigraphy is problematic. We have only differentiated four species of Reticulofenestra that have biostratigraphic potential at Site 865 as well as in other sequences. See comments for Cyclicargolithus sp.

\section{Reticulofenestra dictyoda (Deflandre in Deflandre and Fert, 1954) Stradner in Stradner and Edwards, 1968} (Pl. 9, Figs. 23-26; Pl. 13, Figs. 9-10)

Remarks. This species is small and has a fairly closed central area. It evolves into the larger $R$. umbilicus by increasing in size and opening of the central area. We have not used an intermediate taxon, $R$. samodurovii, to separate these end-members.

Reticulofenestra? "grandis"

(PI. 12, Figs. 15-17 and 22-23)

Remarks. This informally used taxon occurs in the middle Eocene in both holes. It has a bright rim (hence, the assignment to Reticulofenestra?) and a somewhat complex central area structure. The smaller form (PI. 12, Figs. 17 , 22,23 ) may belong to $R$. onusta (Perch-Nielsen, 1971) Wise, 1983.

\section{Reticulofenestra hillae Bukry and Percival, 1971}

(PI. 9. Figs. 31-32)

Remarks. This species has a rounder shape, a wider tube, and a smaller central opening than $R$. umbilicus. We have not specified its lower size limit, and specimens in the 10 - to $12-\mu \mathrm{m}$-size range have been included.

Reticulofenestra reticulata Gartner and Smith, 1967

(Pl. 9, Figs. 33-34)

Reticulofenestra umbilicus (Levin, 1965) Martini and Ritzkowski, 1968 (Pl. 9, Figs. 29-30)

Remarks. This species evolved from $R$. dictyoda by gradually increasing in size through Zone NP15 (CP13). As suggested by Backman and Hermelin (1986), we used a lower size limit of $14 \mu \mathrm{m}$ to separate this species from R. dictyoda.

Rhabdosphaera inflata Bramlette and Sullivan, 1961

$$
\text { (Pl. 12, Figs. 18-19) }
$$

Sphenolithus anarrhopus Bukry and Bramlette, 1969

$$
\text { (PI. 7, Fig. 20) }
$$

Remarks. The spine of this species varies considerably in length. We have included forms with spines over half the length of the sphenolith and others with spines that are barely visible (e.g., PI. 7, Fig. 20). The latter are particularly prevalent toward the top of the range of this taxon. Because we include forms with such minor spines, our range for this species is quite different from other authors

Sphenolithus conspicuus Martini, 1976

(PI. 7, Figs. 17-19)
Remarks. A marked transition of forms between S. conspicuus, S. editus, and $S$. anarrhopus was observed in Zone NP11. Forms were observed that exhibit only partial extinction of the spine (transitional between $S$. conspicuus and S. editus) or a very short spine (transitional between $S$. conspicuus and $S$. anarrhopus). To be classified as $S$. conspicuus, a form must have a long spine that exhibits complete extinction.

\section{Sphenolithus editus Perch-Nielsen in Perch-Nielsen et al., 1978}

(PI. 7. Figs. 15-16)

Remarks. This species appears to give rise to $S$. orphanknollensis, as proposed by Perch-Nielsen (1985). As suggested by Aubry (1983), this species does not have an elongated spine, as in S. radians (see remarks for that species).

Sphenolithus furcatolithoides Locker, 1967

(PI. 7, Fig. 34)

Sphenolithus moriformis (Brönnimann and Stradner, 1960) Bramlette and Wilcoxon, 1967

(PI. 7. Figs. 13-14)

Remarks. We have not differentiated between this form and Sphenolithus primus Perch-Nielsen, 1971.

Sphenolithus obtusus Bukry, 1971

(PI. 7, Figs. 26, 31, and 35)

Sphenolithus orphanknollensis Perch-Nielsen, 197

(PI. 7, Fig. 25)

Sphenolithus predistentus Bramlette and Wilcoxon, 1967

(Pl. 7, Figs. 36-37)

Sphenolithus pseudoradians Bramlette and Wilcoxon, 1967

(PI. 7, Figs. 32-33)

Remarks. This species evolved gradually from $S$. radians during the middle and late Eocene, and a variety of intermediate forms were observed in Site 865. These two taxa differ in two major ways (Aubry, 1985): the basal shield of S. pseudoradians is wider; and the apical spine of this species is outwardly convex, whereas that of $S$. radians has fairly straight sides. Because the FO of $S$. pseudoradians has biostratigraphic potential, we used strict species concepts for this taxon. We included those specimens that have convex spines (but are narrow) and those that are very short, both of which occur substantially farther downsection, in $S$. radians.

Sphenolithus radians Deflandre in Grassé, 1952

(Pl. 7, Figs. 21-22)

Remarks. This species evolved from $S$. editus during the earliest Eocene. It can be somewhat difficult to separate these two species; critical are the straight sides of $S$. editus, and the distinct elements of the proximal column in $S$. radians. This species grades into $S$. pseudoradians (see above).

$$
\text { Sphenolithus "spinatus" }
$$$$
\text { (Pl. 7, Figs. 29-30) }
$$

Remarks. This informal taxon refers to a sphenolith with two long spines.

$$
\begin{aligned}
& \text { Sphenolithus spiniger } \text { Bukry, } 1971 \\
& \text { (Pl. 7, Figs. 23-24) } \\
& \text { Sphenolithus stellatus Gartner, } 1971 \\
& \text { (PI. 7, Figs. 27-28) }
\end{aligned}
$$

Remarks. The forms observed at Site 865 were identical to those described from the middle Eocene of the Blake Plateau by Gartner (1971). This species has a restricted range.

\section{Striatococcus pacificanus Bukry, 1971}

Thoracosphaera operculata Bramlette and Martini, 1964

$$
\text { Toweius }
$$

Remarks. It is difficult to differentiate species in this genus, as the central area etches out easily. Many forms observed have been combined in Toweius $\mathrm{sp}$. We only differentiated species when their morphology was well preserved.

\section{Toweius callosus Perch-Nielsen, 1971}

$$
\text { (Pl. 9, Figs. 19-20) }
$$


Remarks. This form was differentiated by its fairly bright inner cycle. which has a smooth edge and a rounded central area. An etched T. eminens has a slightly rougher edge and a less birefringent inner cycle. It was difficult to differentiate these two species consistently in Site 865 because variable etching of the central area resulted in considerable gradation between these two forms. The FO of $T$. callosus, therefore, might be farther downhole than shown.

Toweius eminens (Bramlette and Sullivan, 1961) Perch-Nielsen, 1971 (Pl. 9, Figs. 13-16; Pl. 14, Figs. 1-3)

Remarks. It was difficult to differentiate this species from $T$. occultatus and $T$. pertusus when etched (see range of forms in Pl. 14, Figs. 1-3).

Toweius gammation (Bramlette and Sullivan, 1961) Romein, 1979 (Pl. 9, Figs. 21-22)

Toweius occultatus (Locker, 1967) Perch-Nielsen, 1971 (Pl. 9, Figs. 17-18)

Remarks. Several samples in the lower Eocene possess the characteristic two "bars" of T. occultatus. However, we also observed a complete variety of gradations between this morphology and that of $T$. eminens, including wellpreserved specimens of $T$. eminens in which the bars parallel to the short axis are wider than those parallel to the long axis (Pl. 9, Figs. 15-16; PI. 14, Figs, $1-2)$. Clearly, these gradations of one form were caused by etching. Although we do not think that $T$. occultatus is a true species, we have indicated the range of these morphologies in Tables 1 and 2.

$$
\text { Toweius pertusus (Sullivan, 1965) Romein, } 1979
$$

$$
\text { (Pl. 9, Figs. 7-10) }
$$

Remarks. The LO of this species was difficult to determine in Site 865 as the central areas of most specimens have been etched.

$$
\begin{gathered}
\text { Toweius sp. } \\
\text { (Pl. 9, Figs, 11-12) }
\end{gathered}
$$

Remarks. A form having a Toweius shield, but an etched central area, was found to be abundant in the upper Paleocene and lower Eocene of Site 865.

\section{Tribrachiatus}

Remarks. This genus is susceptible to overgrowth, which radically changes its form (e.g., Hekel, 1968). We observed only two specimens (both of $T$. orthostylus) that were not overgrown. The triangular shape of overgrown specimens of $T$. orthostylus has been observed quite commonly. We subdivided overgrown specimens of two other species of this genus, $T$. bramlettei and $T$. contortus, on somewhat theoretical grounds. A perfectly overgrown specimen of $T$. bramlette i should have a hexagonal shape, and numerous such forms were observed in the lower Eocene of Site 865. Overgrown T. contortus should have a form intermediate between hexagonal and triangular: that is, a hexagon with alternating long and short sides. A clear evolution was observed among the three forms described, beginning with hexagonal and ending with triangular.
The relative ranges of these different forms with other markers match those proposed for the three species of Tribrachiatus (Perch-Nielsen, 1985) (e.g., Table 5). However, because of the absence of conclusive evidence of original shape, particularly for the older two species, the biostratigraphic application of these species has been somewhat cautious. Only low birefringence specimens (first-order gray and white) were included in Tribrachiatus. There is a possibility that we have mistaken the forms described above for species of Rhombaster (such as R. cuspis).

Tribrachiatus bramlettei? (Brönnimann and Stradner, 1960)

Proto Decima et al., 1975

(Pl. 12, Fig. 1)

Remarks. See comments above.

Tribrachiatus contortus? (Stradner, 1963) Bukry, 1972

$$
\text { (PI. 12, Fig. 2) }
$$

Remarks. See comments above.

Tribrachiatus orthostylus Shamrai, 1963

(Pl. 12, Figs. 3-4)

Remarks. See comments above.

Triquetrorhabdulus inversus

(PI. 12, Figs. 13-14)

Zygodiscus adamas Bramlette and Sullivan, 1961

(PI. 10, Figs. 3-6)

Remarks. Infilling of the central area prevented use of the size of the openings to differentiate species, as used by Perch-Nielsen (1985). The only reliable feature to use in our material was the shape of the bridge. This is diamond-shaped in Z. adamas and rectangular in Z bramlettei. Owing to pervasive overgrowth, we combined Z. herlynii with Z adamas. Several specimens observed near the Paleocene/Eocene boundary have minute $(<0.5 \mu \mathrm{m}$ wide) bridges.

$$
\text { Zygodiscus bramlettei Perch-Nielsen, } 1981
$$$$
\text { (Pl. 10, Figs. 7-10) }
$$

Remarks. See comments for $Z$. adamas.

$$
\begin{gathered}
\text { Zygrhablithus bijugatus (Deflandre in Deflandre and Fert, 1954) } \\
\text { Deflandre, 1959 } \\
\text { (Pl. 12, Figs. 9-12) }
\end{gathered}
$$

Remarks. This species was somewhat difficult to differentiate from Fasciculithus tympaniformis in the uppermost Paleocene because the shape of these two taxa was similar in this interval (e.g., Pl. 12, Figs. 9-10). The two segments of Z. bijugatus are crystallographically disconnected and thus are extinct at different angles in cross-polarized light. 

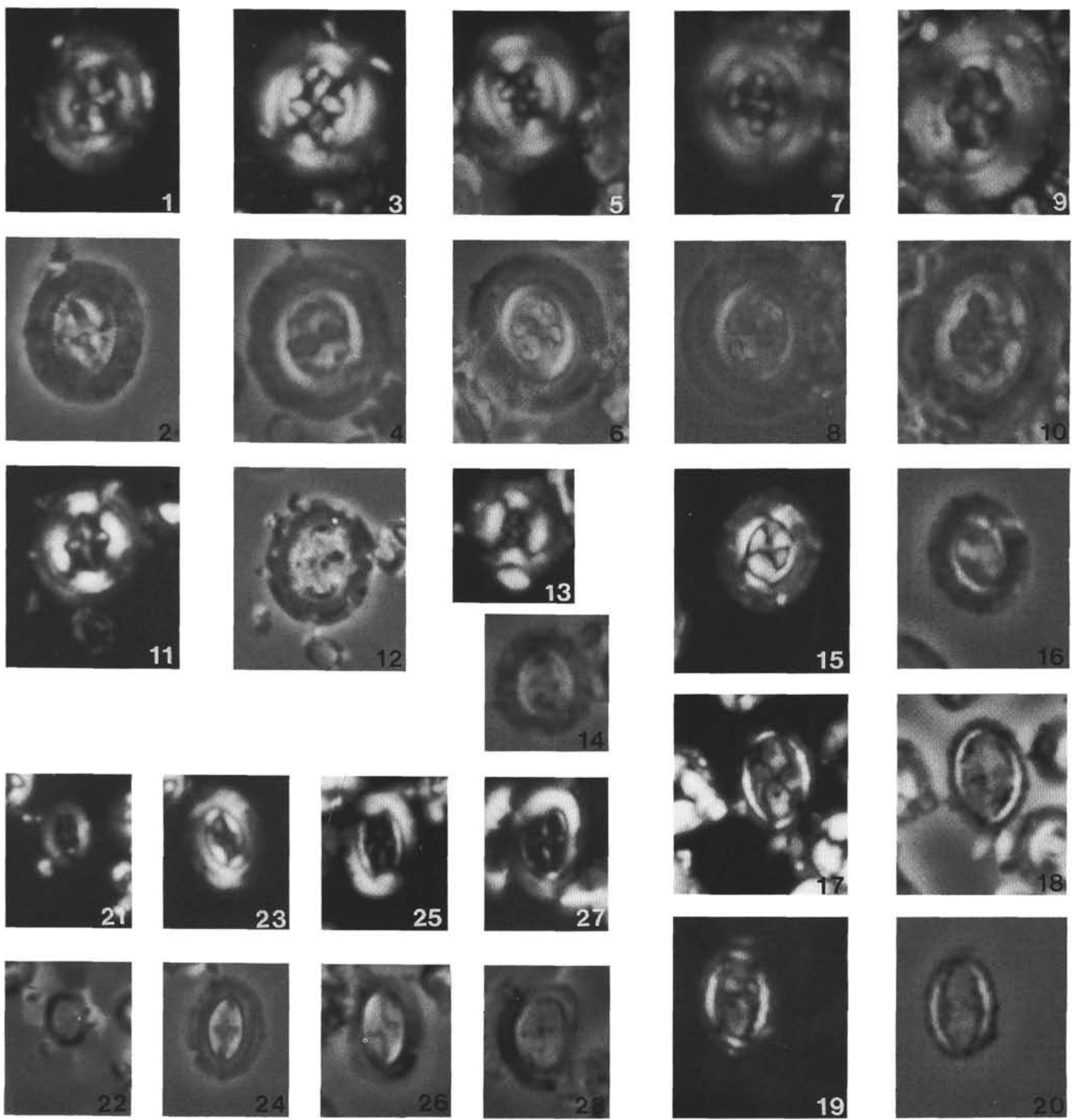

Plate 1. Coccolithaceae. 1-6. Cruciplacolithus tenuis, (1-2) Sample 143-865B-11H-3, 70-71 cm; (3-4) Sample 143-865B-13H-4, 18-20 cm; (5-6) Sample 143-865B-12H-1,70-72 cm. 7-8. Cruciplacolithus frequens, Sample 143-865B-12H-CC. 9-10. Cruciplacolithus asymmetricus, Sample 143-865B-12H1, 20-22 cm. 11-12. Cruciplacolithus sp., Sample 143-865C-12H-CC. 13-14. Birkelundia staurion, Sample 143-865B-9H-2, 20-22 cm. 15-16. Cruciplacolithus cribellum, Sample 143-865B-9H-3, 20-22 cm. 17-20. Cruciplacolithus vanheckii, (17-18) Sample 143-865C-8H-5, 10-11 cm; (19-20) Sample 143-865B-8H-1, 89-91 cm. 21-26. Campylosphaera eodela, (21-22) Sample 143-865B-13H-3, 21-23 cm; (23-24) Sample 143-865B-11H-6, 70-71 cm; (25-26) Sample 143-865C-10H-6, 10-11 cm. 27-28. Campylosphaera dela, Sample 143-865B-9H-3, 20-22 cm. Magnification in all plates is $2500 \times$. 

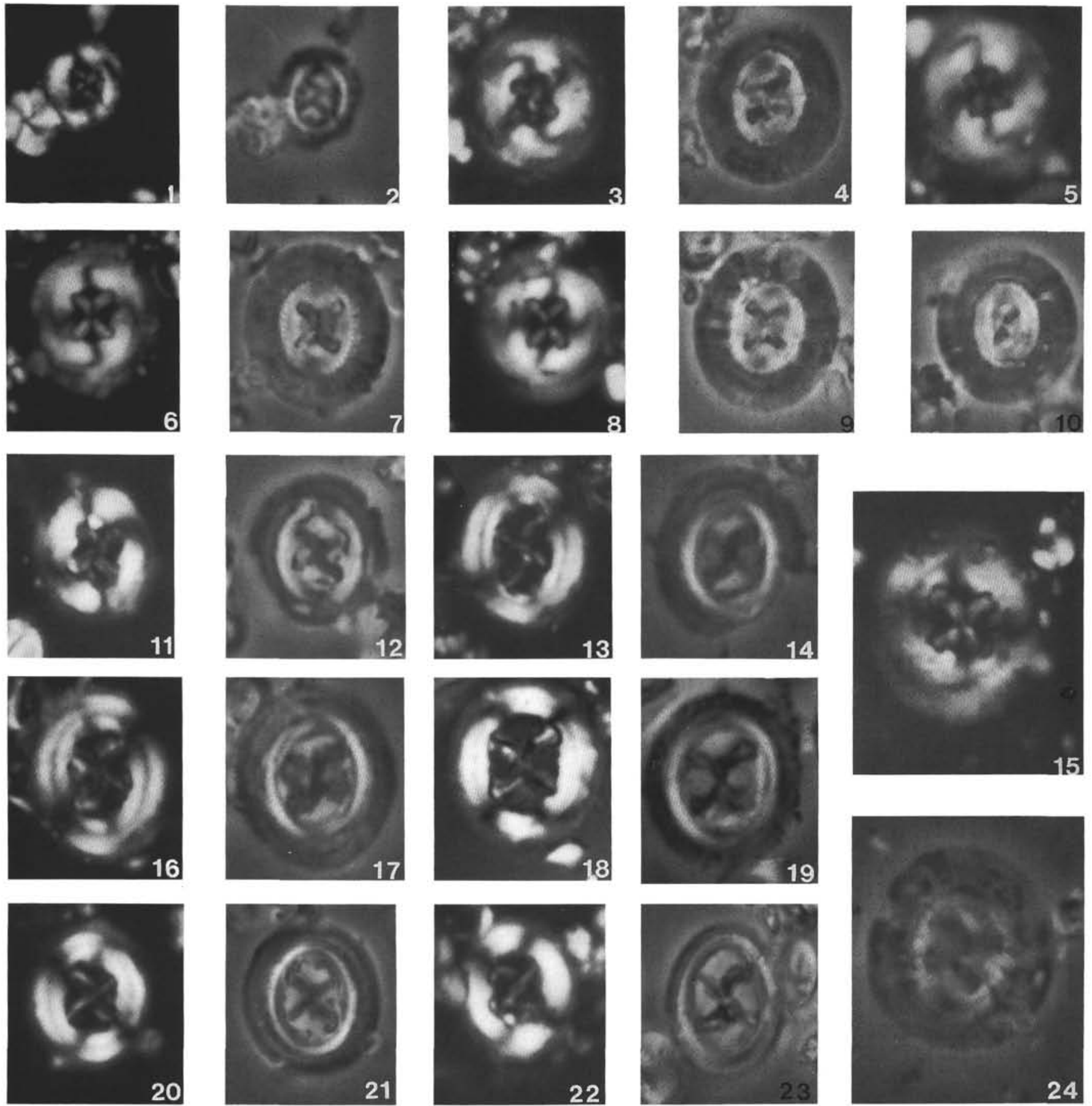

Plate 2. Coccolithaceae. 1-2. Chiasmolithus danicus, Sample 143-865C-15H-3, 10-11 cm. 3-10. Chiasmolithus consuetus, (3-4) Sample 143-865B-11H6, 70-71 cm; $(5,10)$ Sample 143-865B-11H-3, 70-71 cm; (6-7) Sample 143-865B-11H-1, 70-71 cm; (8-9) Sample 143-865B-12 H-3, 70-72 cm. 11-12. Chiasmolithus bidens, Sample 143-865B-12H-5, $100 \mathrm{~cm}$. 13-14, 16-17. Chiasmolithus solitus, (13-14) Sample 143-865C-12H-1, 80 cm; (16-17) Sample 143-865B-10H-5, 111-116 cm. 15, 24. Chiasmolithus californicus, Sample 143-865C-12H-5, 70-72 cm. 18-21. Chiasmolithus medius, Sample 143-865C6H-CC. 22-23. Chiasmolithus eograndis, Sample 143-865C-11H-4, 20-21 cm. Magnification in all plates is $2500 \times$. 

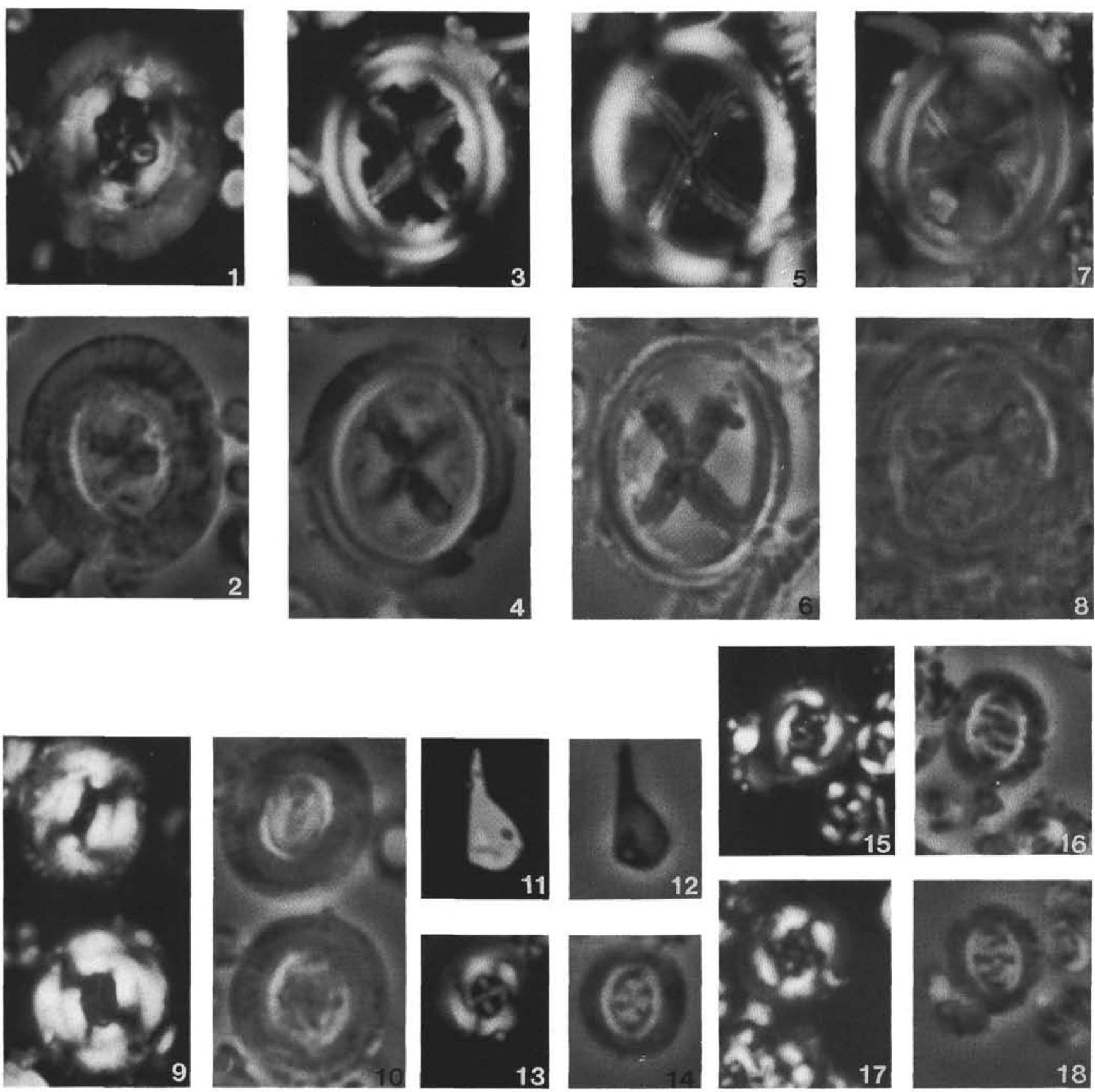

Plate 3. Coccolithaceae. 1-2. Chiasmolithus gigas, Sample 143-865C-8H-1, 10-11 cm. 3-4. Chiasmolithus grandis, Sample 143-865C-5H-4, 100 cm. 5-6. Chiasmolithus expansus, Sample 143-865B-8H-1, 89-91 cm. 7-8. Chiasmolithus oamaruensis, Sample 143-865C-3H-5, 10-11 cm. 9-10. Two specimens of Ericsonia insolita, Sample 143-865C-9H-3, 10-11 cm. 11-12. Bramletteius serraculoides, Sample 143-865C-3H-4, $10-12 \mathrm{~cm} .13-18$. Chiasmolithus nitidus, (13-14) Sample 143-865C-8H-3, 98 cm; (15-16) Sample 143-865C-5H-5, 100 cm; (17-18) Sample 143-865B-8H-2, 70-72 cm. Magnification in all plates is $2500 \times$. 

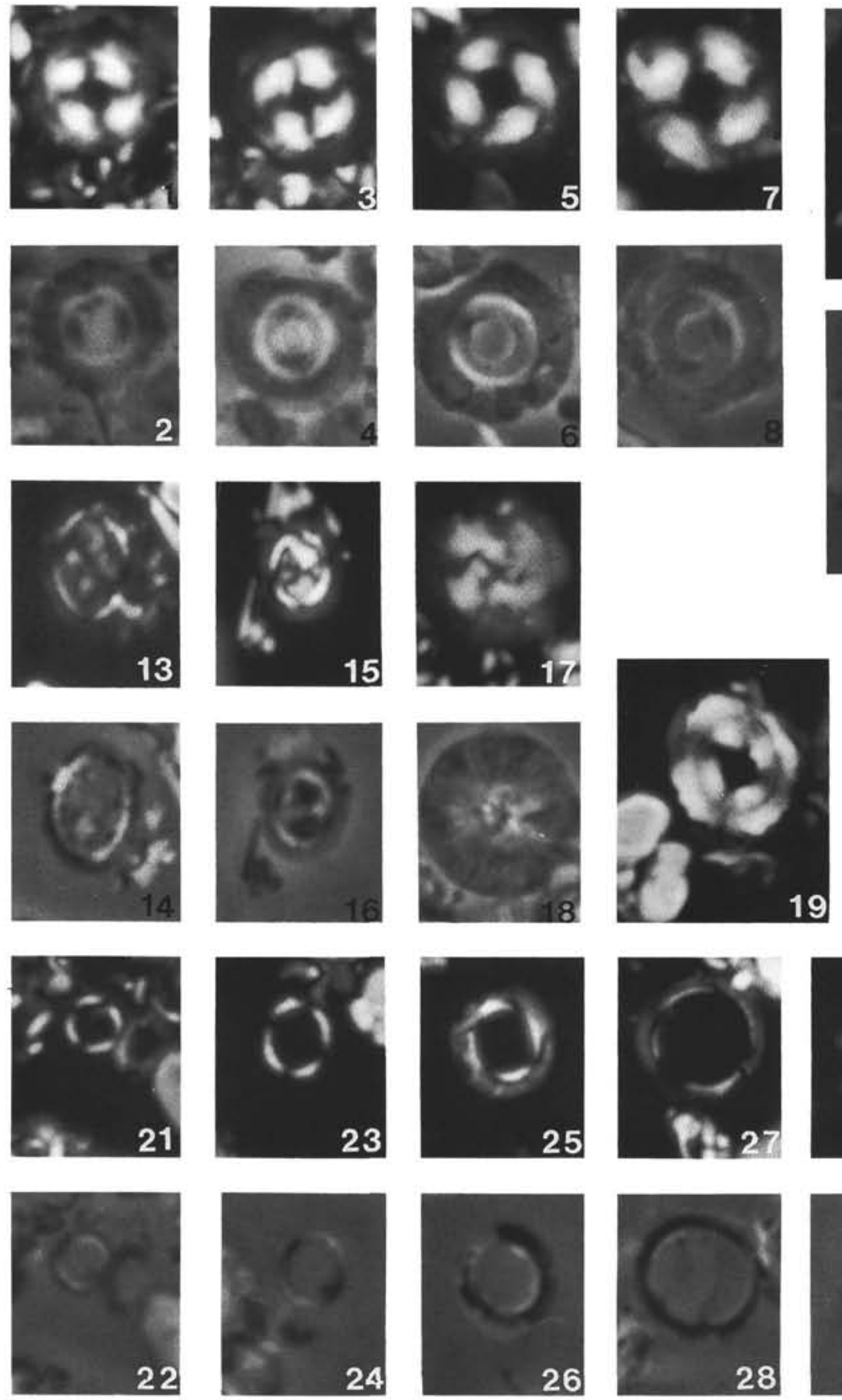
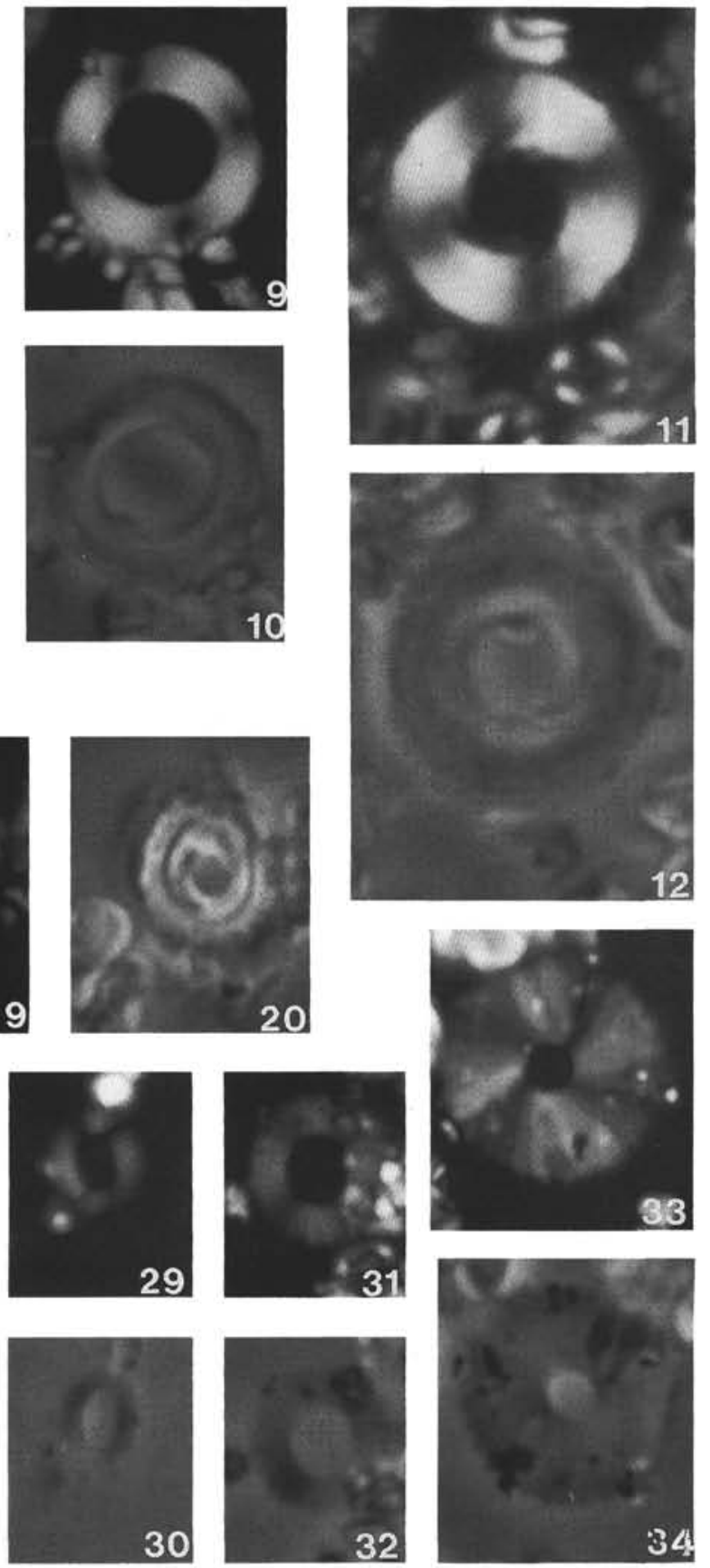

Plate 4. Coccolithaceae. 1-4. Ericsonia subpertusa, (1-2) Sample 143-865B-11H-1, 70-71 cm; (3-4) Sample 143-865C-12H-3, 110-112 cm. 5-6. Ericsonia formosa, Sample 143-865B-9H-CC. 7-8. Ericsonia robusta, Sample 143-865B-12H-2, 70-72 cm. 9-12. Ericsonia cf. E. robusta, (9-10) Sample 143-865C-13H-3, 10-11 cm; (11-12) Sample 143-865B-13H-1, 21-23 cm. 13-14. Ericsonia obruta, Sample 143-865B-6H-3, 70-72 cm. 15-16. Ericsonia subdisticha, Sample 143-865C-3H-3, 10-11 cm. 17-18. Markalius inversus, Sample 143-865B-11H-3, 70-71 cm. 19-20. Coccolithus crassus, Sample 143-865B-9H-4, 10-12 cm. 21-24. Coronocyclus nitescens, Sample 143-865B-11H-3, 70-72 cm. 25-28. Calcidiscus protoannulus, (25-26) Sample 143865B-5H-1, 70-72 cm; (27-28) Sample 143-865C-8H-1, 10-11 cm. 29-30. Pedinocyclus "prelarvalis," Sample 143-865B-11H-CC. 31-34. Pedinocyclus larvalis, (31-32) Sample 143-865B-10H-2, 4-6 cm; (33-34) Sample 143-865C-8H-1, 10-11 cm. Magnification in all plates is 2500x. 

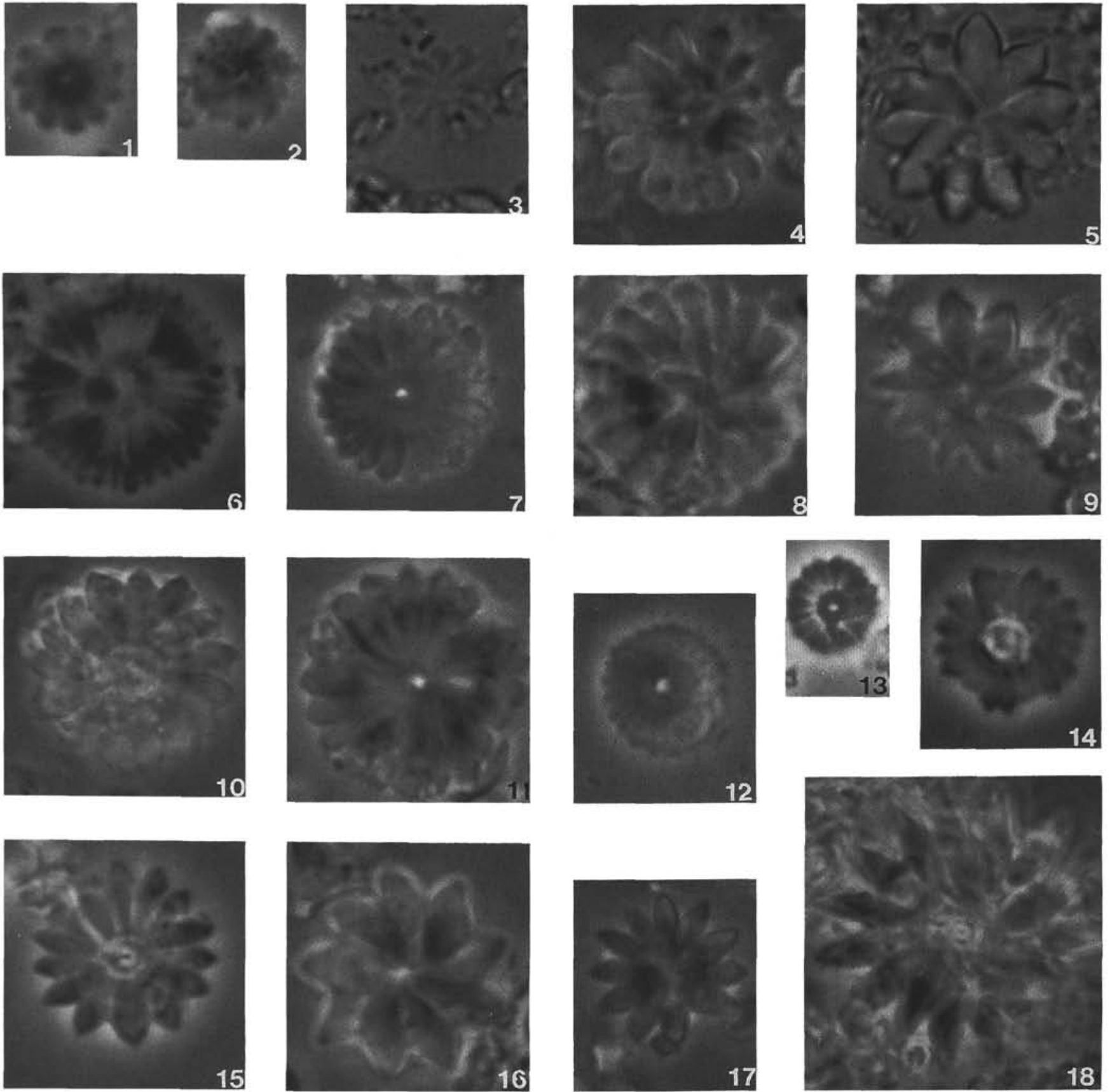

Plate 5. Discoasteraceae. 1. Discoaster sp., Sample 143-865B-12H-1, 20-22 cm. 2-4. Discoaster mohleri, (2) Sample 143-865B-14H-2, 20-22 cm; (3) Sample 143-865B-13H-1, $100 \mathrm{~cm}$; (4) Sample 143-865B-12H-3, 70-72 cm. 5,9. Discoaster nobilis, (5) Sample 143-865B-12H-2, 120-125 cm; (9) Sample 143-865B-12H-1, $110 \mathrm{~cm}$. 6-8, 11. Discoaster multiradiatus, (6) Sample 143-865C-13H-2, $80 \mathrm{~cm}$; (7) Sample 143-865B-11H-CC; (8) Sample 143-865B10H-4, 4-6 cm; (11) Sample 143-865C-11H-3, 70-72 cm. 10. Discoaster elegans, Sample 143-865B-11H-3, 70-71 cm. 12-13. Discoaster lenticularis, (12) Sample 143-865C-12H-1, 20-22 cm; (13) Sample 143-865C-11H-3, 70-72 cm. 14. Discoaster cf. D. diastypus, Sample 143-865B-10H-4, 61-62 cm. 15. Discoaster barbadiensis, Sample 143-865B-10H-5, 111-116 cm. 16-17. Discoaster sp., (16) Sample 143-865B-12H-2, 120-125 cm; (17) Sample $143-865 \mathrm{C}-12 \mathrm{H}-1,20-21 \mathrm{~cm}$. 18. Discoaster boulangeri, Sample 143-865B-10H-4, 60-62 cm. Magnification in all plates is $2500 \times$. 

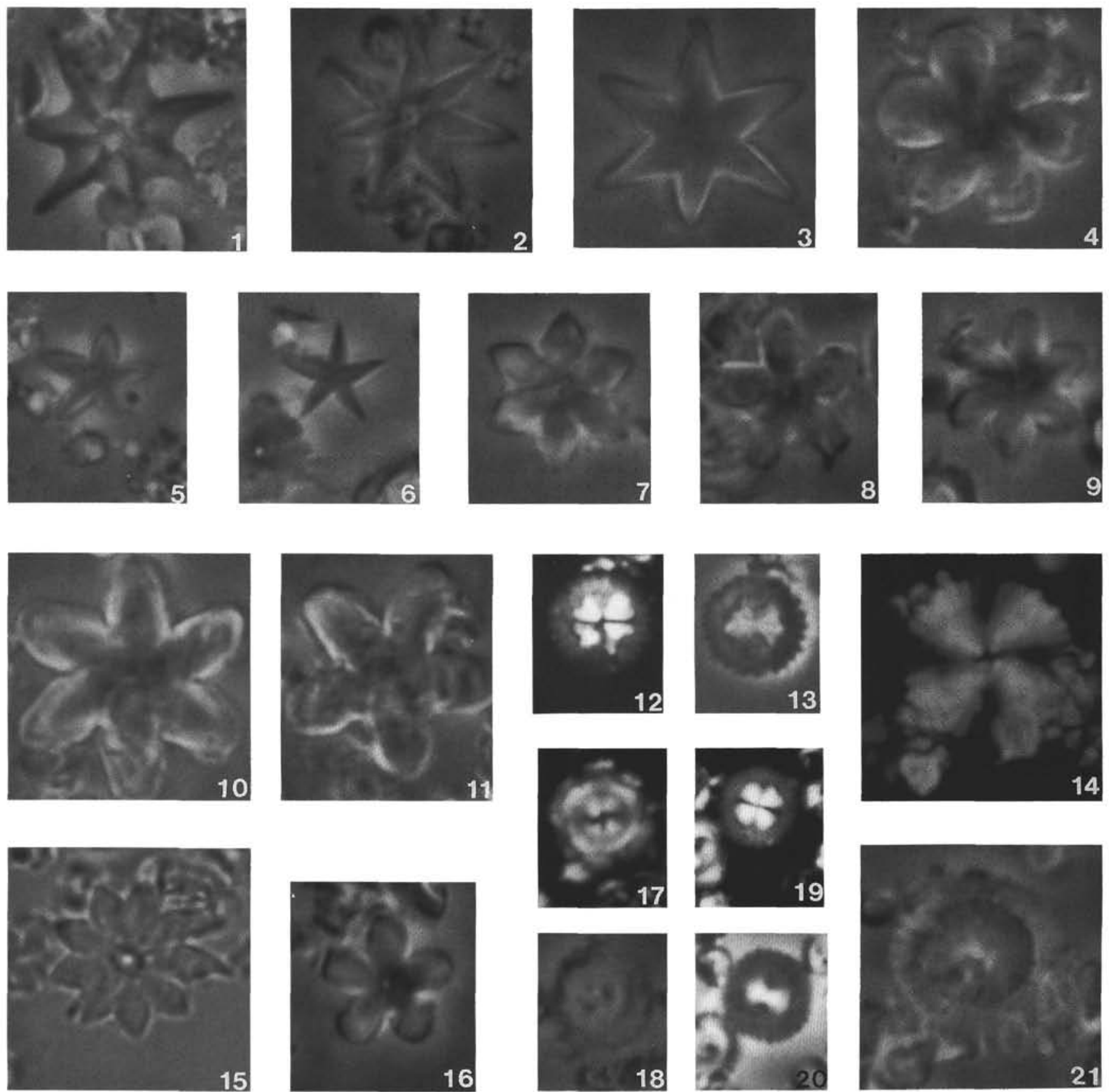

Plate 6. Discoasteraceae and Heliolithaceae. 1-3. Discoaster lodoensis, (1) Sample 143-865B-9H-4, 10-11 cm; (2) Sample 143-865C-10H-CC; (3) Sample 143-865B-10H-3, 60 cm. 4. Discoaster deflandrei, Sample 143-865C-3H-5, 10-11 cm. 5-6. Discoaster sublodoensis, (5) Sample 143-865C-9H-3,90 cm; (6) Sample 143-865C-9H-3, 10-11 cm. 7. Discoaster strictus, Sample 143-865C-9H-5, 10-11 cm. 8. Discoaster "pretanii," Sample 143-865C-3H-4, 10-11 cm. 9. Discoaster "prenodifer," Sample 143-865C-3H-4, 10-11 cm. 10. Discoaster nodifer, Sample 143-865C-4H-6, 10-11 cm. 11. Discoaster tanii, Sample 143-865C-3H-4, 10-11 cm. 12-13, 19-20. Heliolithus? floris, (12-13) Sample 143-865B-14H-2, 20-22 cm; (19-20) Sample 143-865B-14H-1, 116 cm. 14, 21. Heliolithus kleinpellii, Sample 143-865B-14H-3, 25-27 cm. 15. Discoaster saipanensis, Sample 143-865B-8H-3, 70-72 cm. 16. Discoaster sp., Sample 143-865B-3H-CC. 17-18. Heliolithus riedelii, Sample 143-865C-13H-5, 10-11 cm. Magnification in all plates is $2500 \times$. 

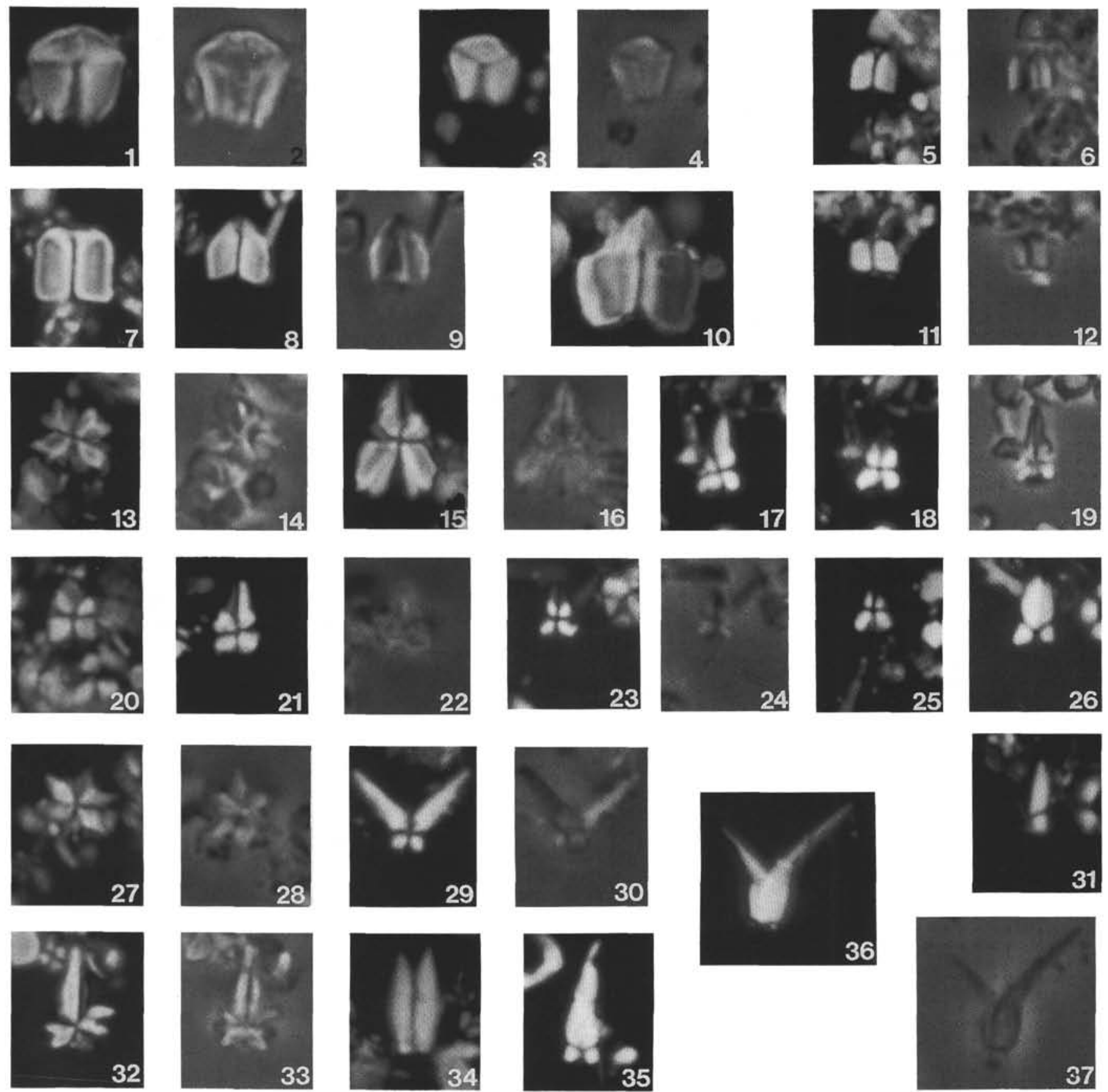

Plate 7. Fasciculithaceae and Sphenolithaceae. 1-4. Fasciculithus pileatus, (1-2) Sample 143-865B-14H-5, 22-24 cm; (3-4) Sample 143-865C-15H-3, 10-11 cm. 5-6. Fasciculithus tympaniformis, Sample 143-865B-12H-1, 4-6 cm. 7. Fasciculithus involutus, Sample 143-865C-12H-3, 50-52 cm. 8-9. Fasciculithus lilianae, Sample 143-865B-12H-1, 18-19 cm. 10. Fasciculithus schaubii, Sample 143-865B-12H-1, 20-22 cm. 11-12. Fasciculithus aubertae, Sample 143-865B-12H-1, 18-19 cm. 13-14. Sphenolithus moriformis, Sample 143-865C-3H-4, 10-12 cm. 15-16. Sphenolithus editus, Sample 143-865C-9H-5, 10-11 cm. 17-19. Sphenolithus conspicuus, Sample 143-865C-11H-1, 60-61 cm (same specimen at different angles). 20. Sphenolithus anarrhopus, Sample 143-865B-14H-3,25-27 cm. 21-22. Sphenolithus radians, Sample 143-865B-5H-1, 70-72 cm. 23-24. Sphenolithus spiniger, Sample 143-865C-8H-1, 10-11 cm. 25. Sphenolithus orphanknollensis, Sample 143-865B-5H-1, 70-72 cm. 26, 31, 35. Sphenolithus obtusus, (26, 31) Sample 143-865B-4H-3, $91 \mathrm{~cm}$ (same specimen at different angles); (35) Sample 143-865C-4H-CC, 27-28. Sphenolithus stellatus, Sample 143-865B-8H-1,89-91 $\mathrm{cm}$. 29-30. Sphenolithus "spinatus," Sample 143-865C-8H-4, 67-69 cm. 32-33. Sphenolithus pseudoradians, Sample 143-865B-3H-6, 68 cm. 34. Sphenolithus furcatolithoides, Sample 143-865C-4H-CC. 36-37. Sphenolithus predistentus, Sample 143-865C-3H-4, 10-12 cm. Magnification in all plates is $2500 x$. 

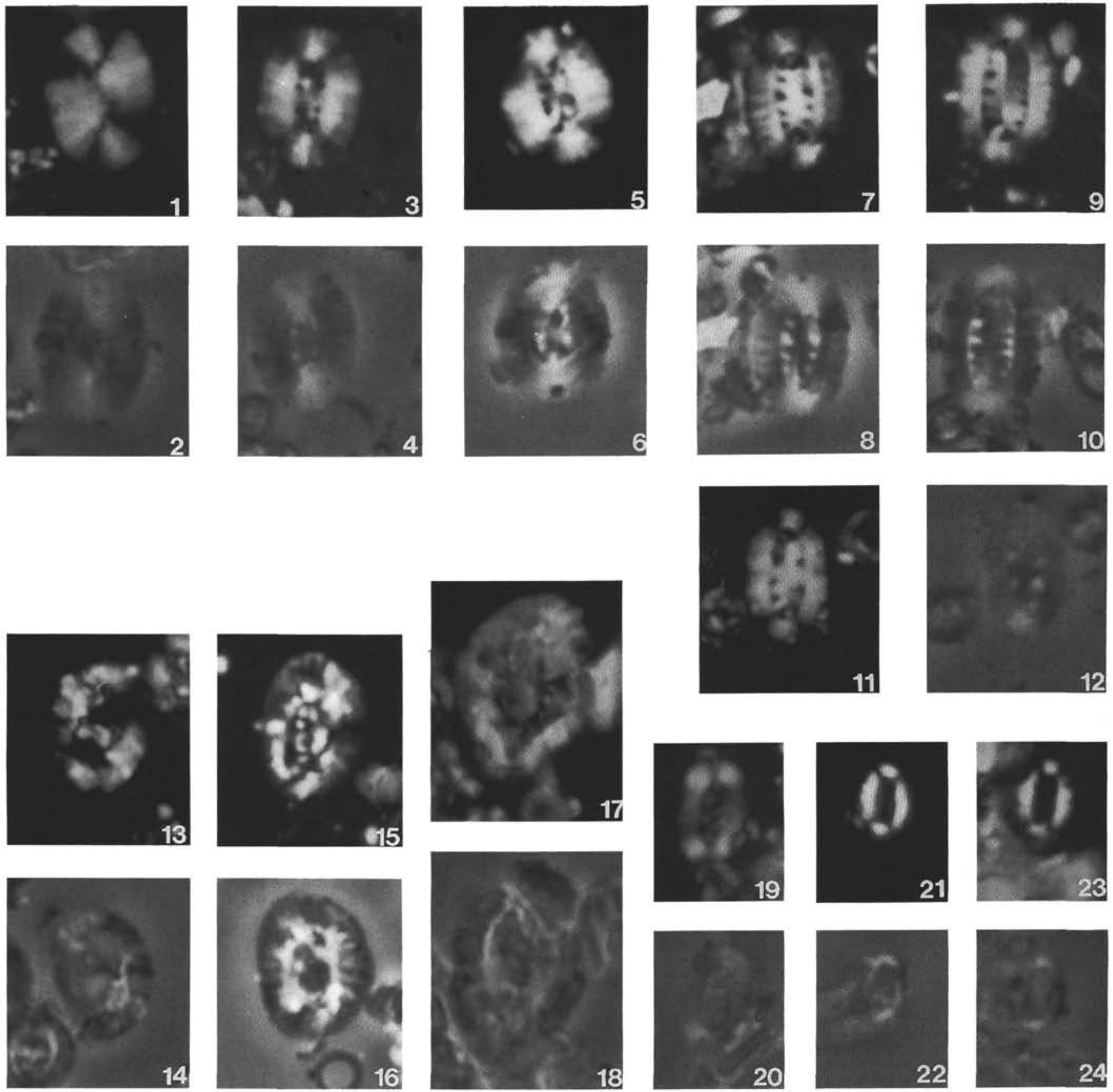

Plate 8. Ellipsolithus and Helicosphaeraceae. 1-2. Ellipsolithus macellus, Sample 143-865C-14H-CC. 3-6. Ellipsolithus bollii, Sample 143-865B-11H-2, $111 \mathrm{~cm}$. 7-12. Ellipsolithus distichus, (7-8) Sample 143-865C-12H-4, 50-52 cm; (9-10) Sample 143-865B-12H-5, 70-72 cm. 13-14. Helicosphaera seminulum, Sample 143-865B-6H-CC. 15-16. Helicosphaera lophota, Sample 143-865C-8H-3, 70-72 cm. 17-18. Helicosphaera reticulata, Sample 143-865C-3H-5, 10-11 cm. 19-20. Ellipsolithus lajollaensis, Sample 143-865B-9H-1, 13-15 cm. 21-24. Ellipsolithus sp., Sample 143-865B-11H-6, 20-22 $\mathrm{cm}$. Magnification in all plates is $2500 \times$. 

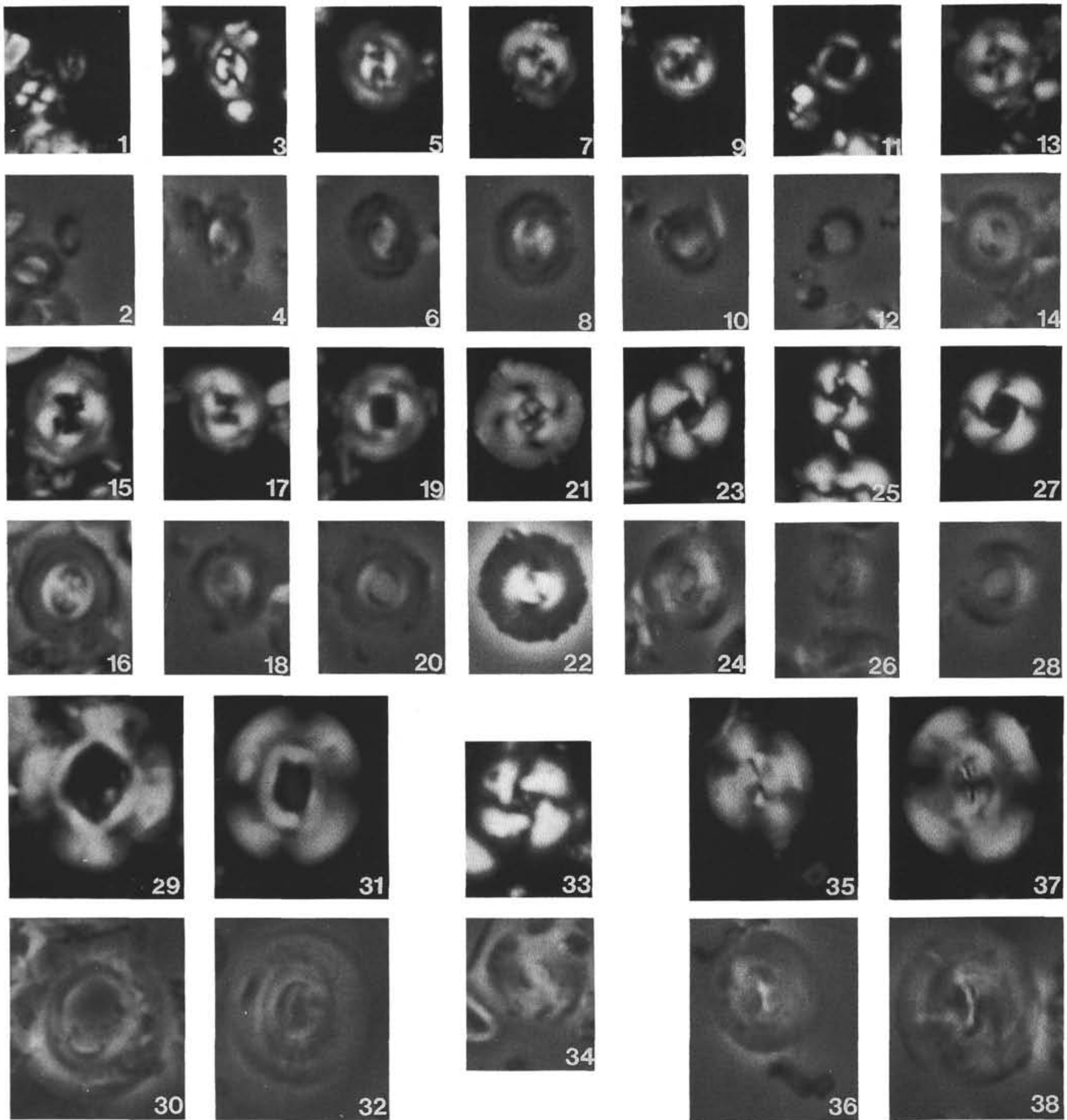

Plate 9. Prinsiaceae. 1-2. Prinsius martinii, Sample 143-865C-15H-3, 10-11 cm. 3-6. Prinsius bisulcus, (3-4) Sample 143-865C-12H-3, 50-52 cm; (5-6) Sample 143-865C-12H-6, 20-22 cm. 7-10. Toweius pertusus, (7-8) Sample 143-865B-12-1, 18-19 cm; (9-10) Sample 143-865C-12H-2, 60-61 cm. 11-12. Toweius sp., Sample 143-865B-12-1, 18-19 cm. 13-16. Toweius eminens, (13-14) Sample 143-865B-14H-6, 17-19 cm; (15-16) Sample 143-865B$11 \mathrm{H}-2,20-22 \mathrm{~cm}$. 17-18. Toweius occultatus, Sample 143-865B-11H-3, 70-72 cm. 19-20. Toweius callosus, Sample 143-865C-10H-4, 10-11 cm. 21-22. Toweius gammation, Sample 143-865B-9H-5, $100 \mathrm{~cm}$. 23-26. Reticulofenestra dictyoda, (23-24) Sample 143-865B-9H-5, 110 cm; (25-26) Sample 143-865C-3H-4, 10-12 cm. 27-28. Cyclicargolithus sp., Sample 143-865C-9H-5, 10-11 cm. 29-30. Reticulofenestra umbilicus, Sample 143-865B-6H-1, 81-83 cm. 31-32. Reticulofenestra hillae, Sample 143-865C-3H-3, 10-11 cm. 33-34. Reticulofenestra reticulata, Sample 143-865B-3H-CC. 35-36. Dictyococcites scrippsae, Sample 143-865C-3H-4, 10-12 cm. 37-38. Dictyococcites bisectus, Sample 143-865C-3H-4, 10-12 cm. Magnification in all plates is $2500 x$. 

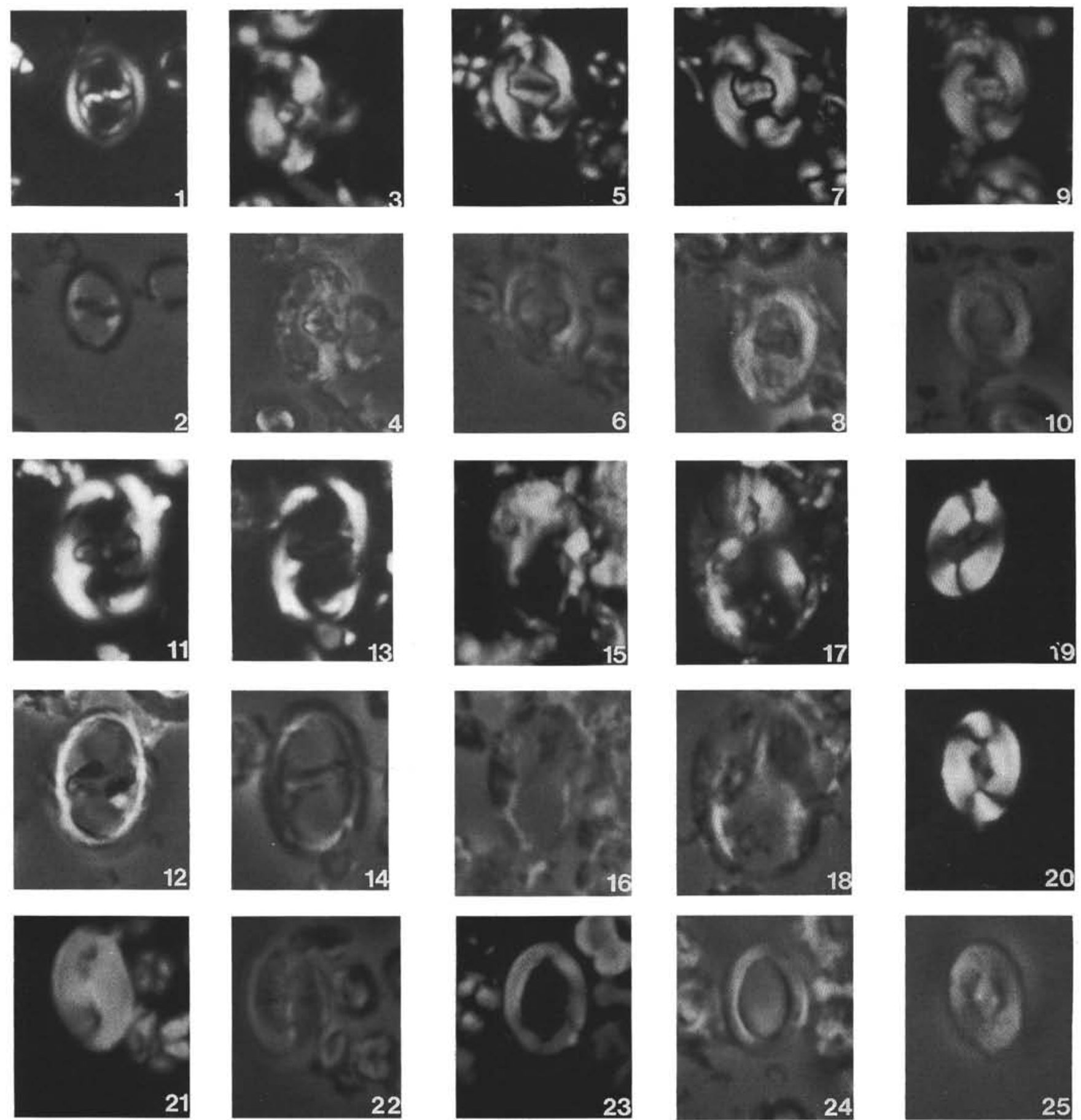

Plate 10. Zygodiscaceae. 1-2. Placozygus sigmoides, Sample 143-865B-11H-4, 110-111 cm. 3-6. Zygodiscus adamas, (3-4) Sample 143-865B-10H-5, 10-11 cm; (5-6) Sample 143-865B-13H-CC. 7-10. Zygodiscus bramlettei, (7-8) Sample 143-865B-13H-4, $100 \mathrm{~cm} ;$ (9-10) Sample 143-865C-13H-4, 10-11 cm. 11-14. Lophodolithus nascens, (11-12) Sample 143-865C-12H-2, 138-139 cm; (13-14) Sample 143-865B-11H-4, 20-22 cm. 15-16. Lophodolithus mochloporus, Sample 143-865C-9H-5, 10-11 cm. 17-18. Lophodolithus rotundus, Sample 143-865B-8H-3, 70-72 cm. 19-20, 25. Neocrepidolithus bukryi, Sample 143-865C-11H-CC (all same specimen). 21-24. Neocrepidolithus sp., (21-22) Sample 143-865B-12H-4, 20-22 cm; (23-24) Sample $143-865 \mathrm{C}-12 \mathrm{H}-2,60-62 \mathrm{~cm}$. Magnification in all plates is $2500 \times$. 

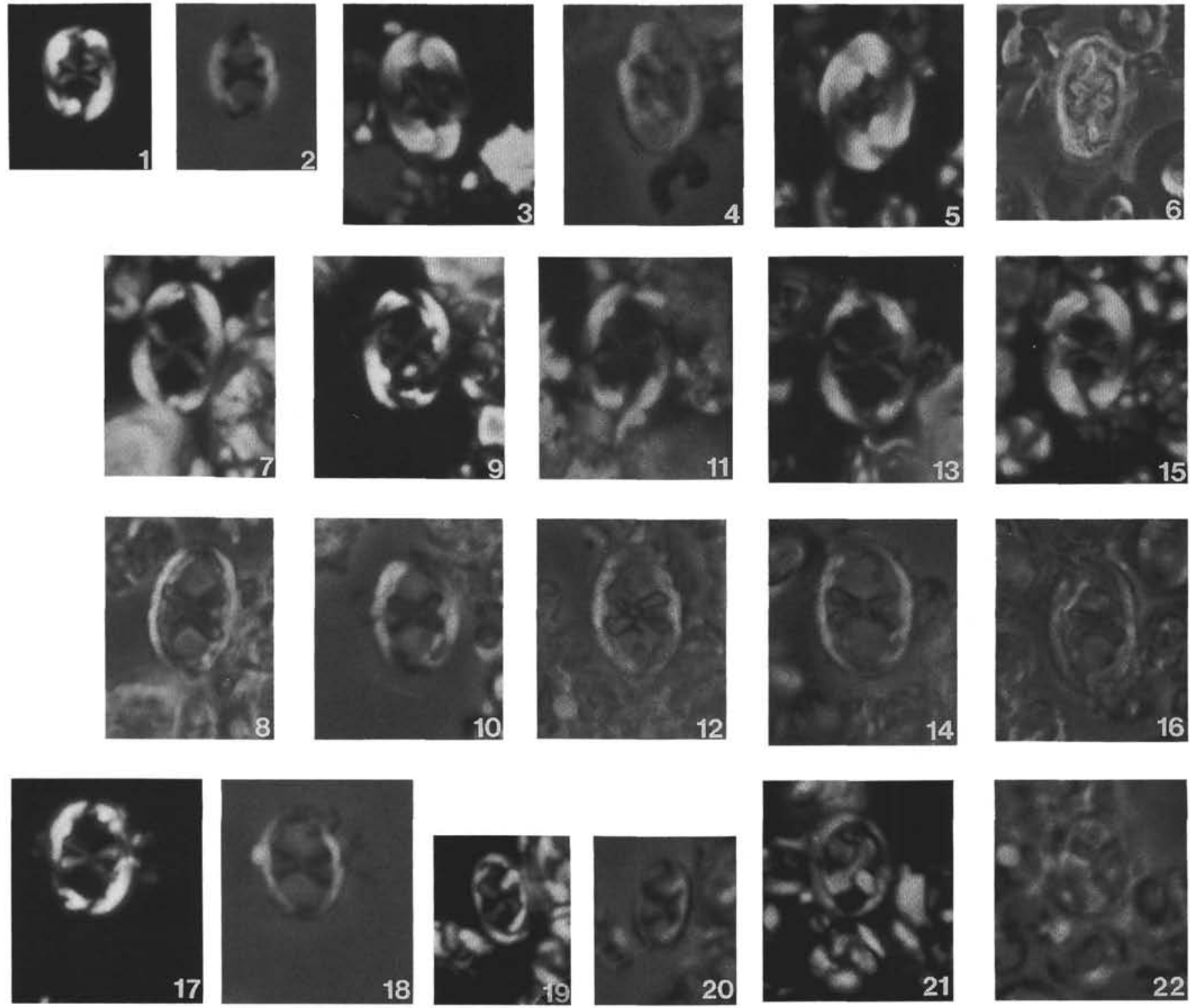

Plate 11. Zygodiscaceae. 1-2. Neochiastozygus concinnus, Sample 143-865B-12H-6, $88 \mathrm{~cm}$. 3-6. Neochiastozygus distentus, (3-4) Sample 143-865B12H-4, 20-22 cm; (5-6) Sample 143-865B-11H-5, 70-71 cm. 7-8. Neochiastozygus modestus, Sample 143-865B-11H-2, 70-71 cm. 9-12. Neochiastozygus perfectus, (9-10) Sample 143-865B-11H-5, 70-71 cm; (11-12) Sample 143-865C-12H-2, $20 \mathrm{~cm}$. 13-18. Neochiastozygus junctus, (13-14) Sample 143-865C12H-1, 112-113 cm; (15-16) Sample 143-865B-11H-5, 70-71 cm; (17-18) Sample 143-865B-12H-5, 70-72 cm. 19-20. Neococcolithes protenus, Sample 143-865B-11H-3, 70-72 cm. 21-22. Neococcolithes dubius, Sample 143-865B-8H-6, 20-22 cm. Magnification in all plates is 2500X. 

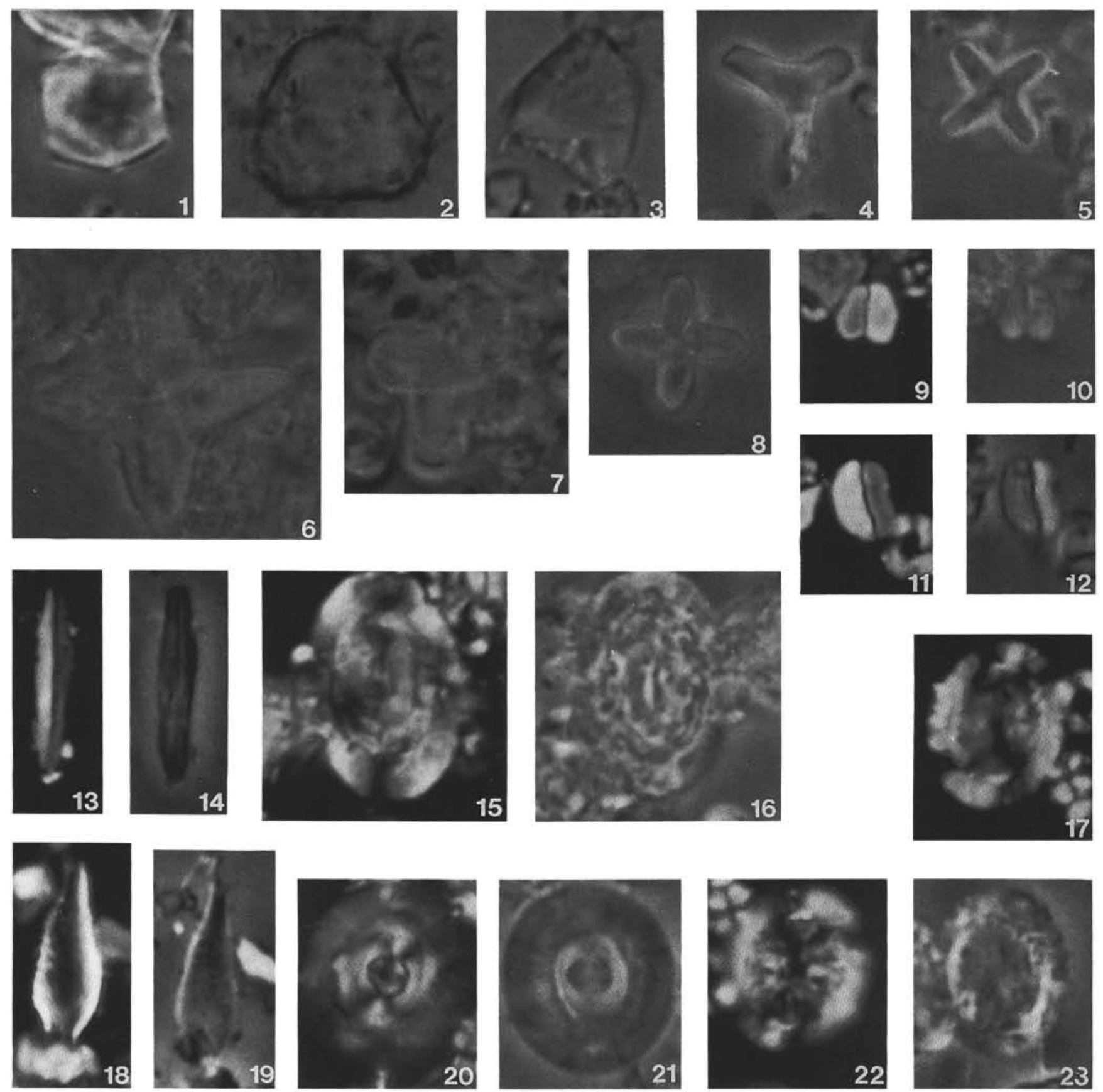

Plate 12. Incertae sedis, various and unknown taxa. 1. Tribrachiatus bramlettei?, Sample 143-865C-11H-4, 20-21 cm. 2. Tribrachiatus contortus?, Sample 143-865B-11H-1, 70-71 cm. 3-4. Tribrachiatus orthostylus, (3) Sample 143-865B-10H-CC; (4) Sample 143-865B-10H-5, 10-11 cm. 5, 8. Nannotetrina sp., Sample 143-865C-9H-CC. 6-7. Nannotetrina fulgens, (6) Sample 143-865B-8H-5, 70-72 cm; (7) Sample 143-865C-6H-CC. 9-12. Zygrhablithus bijugatus, (9-10) Sample 143-865C-11H-4, 110-111 cm; (11-12) Sample 143-865C-8H-1, 10-11 cm. 13-14. Triquetrorhabdulus inversus, Sample 143-865C-8H-1, 10-11 cm. 15-16. Reticulofenestra "grandis" large specimen, Sample 143-865B-6H-6, 70-72 cm. 17, 22-23. Reticulofenestra "grandis" small specimen, Sample 143-865B-6H-6, 70-72 cm. 18-19. Rhabdosphaera inflata, Sample 143-865C-9H-4, 10-11 cm. 20-21. Coccolithus pelagicus, Sample 143-865B-6H-6, 70-72 cm. Magnification in all plates is $2500 \times$. 

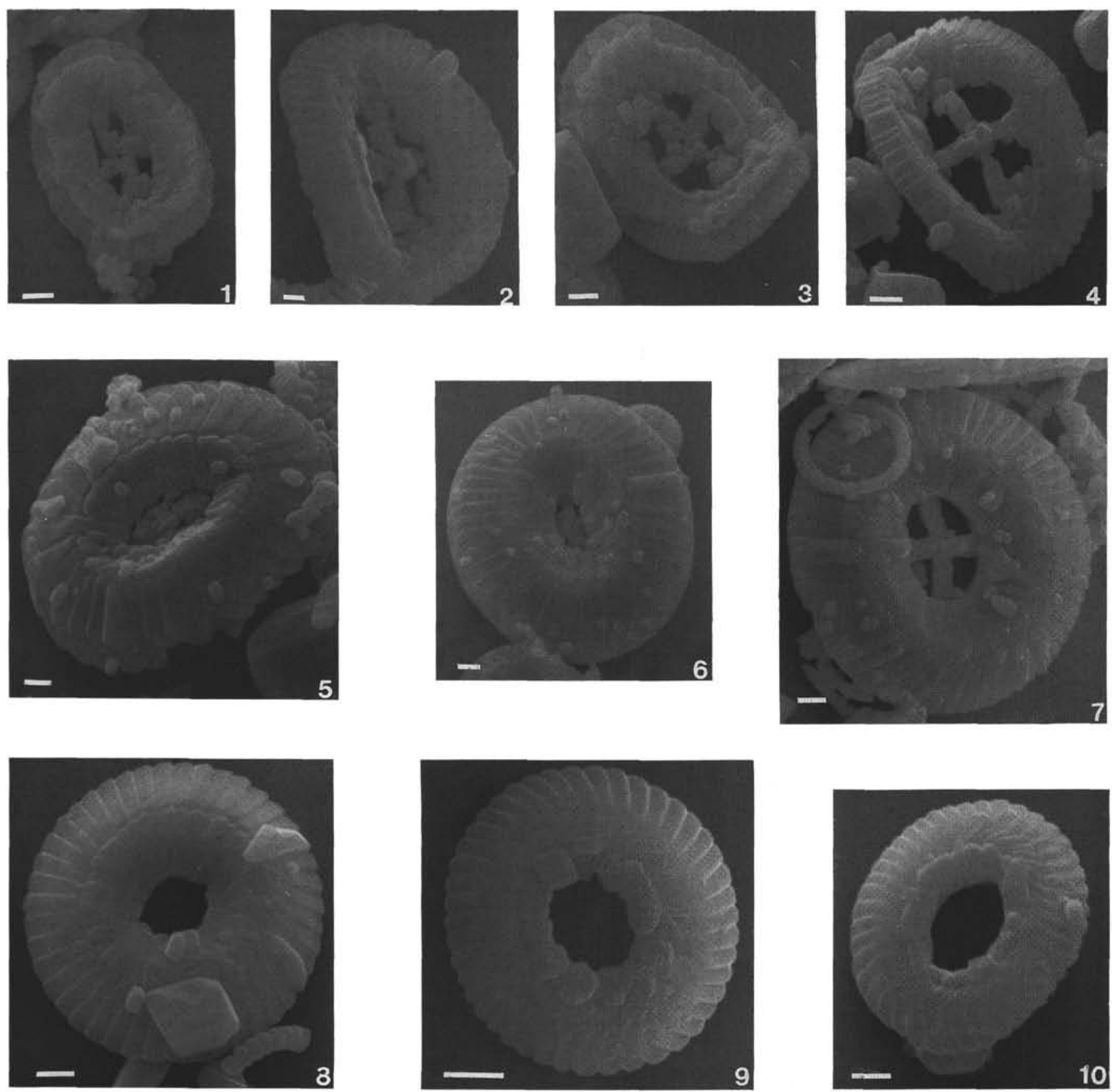

Plate 13. Scanning electron micrographs. 1. Campylosphaera eodela, proximal view, Sample 143-865B-10H-3, 60-62 cm. 2. Campylosphaera sp., irregular specimen, distal view, Sample 143-865B-10H-3, 60-62 cm. 3-4. Campylosphaera dela, (3) proximal view, Sample 143-865B-10H-3, 60-62 cm; (4) distal view, Sample 143-865C-9H-3, 10-12 cm. 5-6. Coccolithus pelagicus, distal views, Sample 143-865C-9H-3, 10-12 cm. 7. Ericsonia insolita, distal view, Sample 143-865C-9H-3, 10-12 cm. 8. Cyclicargolithus sp., distal view, Sample 143-865C-9H-3, 10-12 cm. 9-10. Reticulofenestra dictyoda, distal views, (9) Sample 143-865B-9H-1, 13-15 cm; (10) Sample 143-865C-9H-3, 10-12 cm. Scale bars represent $1 \mu \mathrm{m}$. 

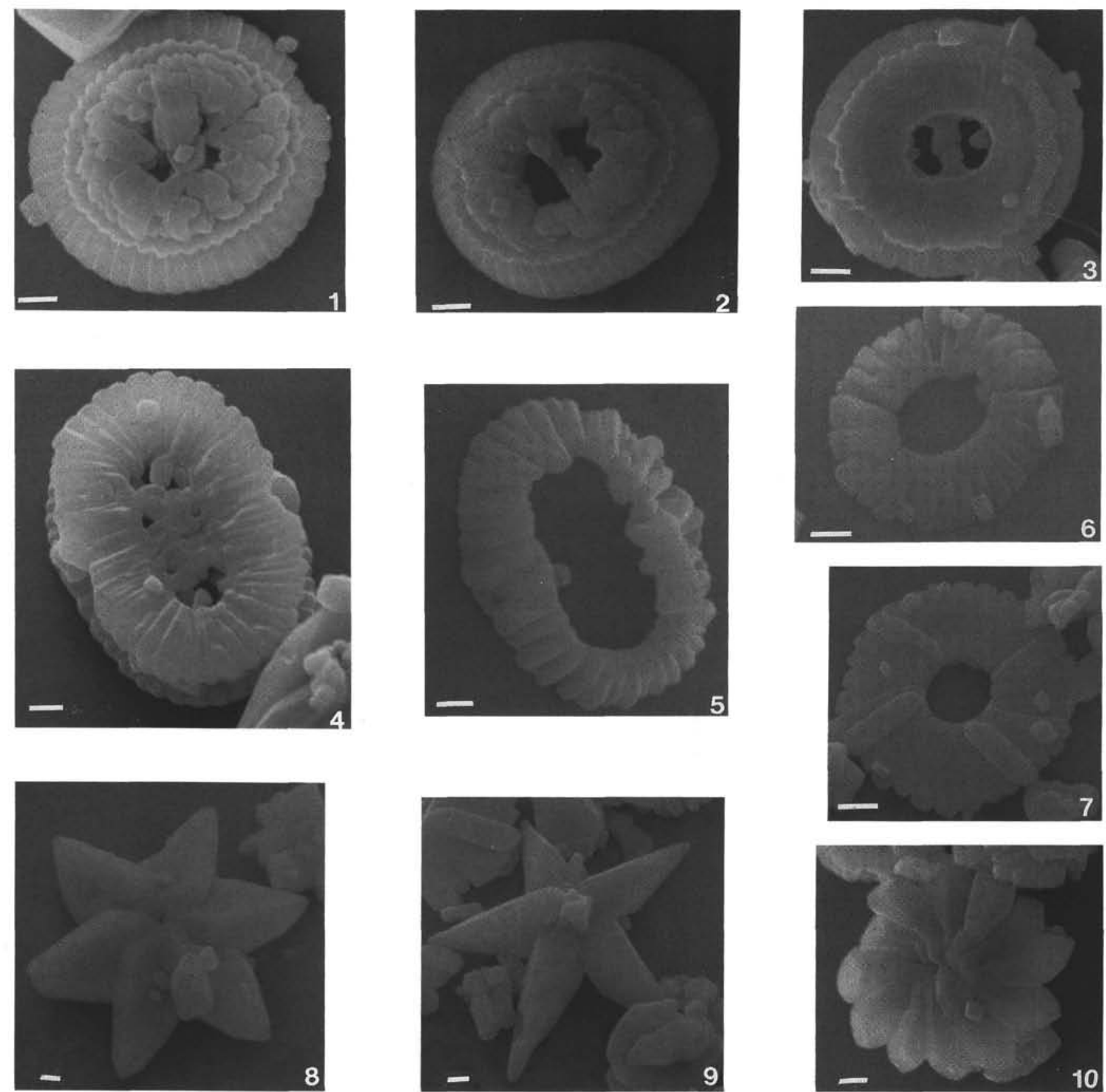

Plate 14. Scanning electron micrographs. 1-3. Toweius eminens, (1) distal view, Sample 143-865C-14H-CC; (2) distal view, Sample 143-865B-12H-2, 70-72 cm; (3) proximal view, Sample 143-865B-12H-4, 20-22 cm. 4. Ellipsolithus lajollaensis, proximal view, Sample 143-865C-9H-3, 10-12 cm. 5. Ellipsolithus sp., distal view, Sample 143-865B-10H-3, 60-62 cm. 6. Pedinocyclus "prelarvalis," distal view, Sample 143-865B-10H-3, 60-62 cm. 7. Pedinocyclus larvalis, distal view, Sample 143-865B-9H-1, 13-15 cm. 8. Discoaster lodoensis, Sample 143-865B-9H-1, 13-15 cm. 9. Discoaster sublodoensis, Sample 143-865B-9H-1, 13-15 cm. 10. Discoaster mohleri (early specimen), Sample 143-865C-14H-CC. Scale bars represent $1 \mu \mathrm{m}$. 